\title{
The Renminbi's Role in the Global Monetary System
}

\author{
Eswar Prasad and Lei Ye
}

We analyze three related but distinct concepts concerning the renminbi's role in the global monetary system: internationalization of the currency; currency convertibility; and reserve currency status. Their sequencing in relation to other policy goals such as financial sector reforms and exchange rate flexibility will affect their benefit-risk trade-offs. We describe the measures taken and progress attained in each of these areas, and discuss the implications of these changes for the balance and sustainability of China's own economic development, as well as the associated implications for the global monetary system.

China runs the risk of putting the cart in front of the horse by pushing forward more aggressively with capital account liberalization than with exchange rate flexibility and financial system reforms. While China is actively promoting the internationalization of its currency, it is a long way from attaining full convertibility or meeting other prerequisites for achieving reserve currency status. Ultimately, China will proceed with capital account convertibility in its own controlled and gradual manner, with the goal being an open capital account but with significant administrative and other soft controls. The renminbi will play an increasingly important role in the international monetary system, but is unlikely to displace the U.S. dollar anytime soon.

\section{Introduction}

China's economy is now the second largest in the world and is a key driver of global growth. Of the currencies of the world's six largest economies, China's renminbi is the only one without reserve currency status. Even though the economy has neither a flexible exchange rate nor an open capital account, the Chinese government has recently taken a number of steps to increase the international use of the renminbi. Given China's sheer size and its rising shares of global GDP and trade, these steps are gaining traction and portend a rising role for the renminbi in global trade and finance.

In this paper, we analyze three aspects of the renminbi's role in the international monetary system: (1) the trajectory of the renminbi's use in the

Authors' note: The authors thank Sun Tao, Shang-Jin Wei, and other colleagues for helpful comments and discussions. 
denomination and settlement of cross-border trade and financial transactions, referred to as the currency's "internationalization"; (2) the likelihood and timing of China's path to currency convertibility; and (3) the prospects for the renminbi attaining reserve currency status. The paper investigates these three related but distinct elements within a unified conceptual framework and evaluates their implications in two dimensions: first, for the balance and sustainability of China's own economic development; and second, for the associated implications for the global monetary system. ${ }^{1}$

A currency's international usage and its convertibility are different concepts, and neither one is a necessary or sufficient condition for the other. Both conditions have to be met, however, for a currency to become an international reserve currency. Given China's size and growth prospects, it is widely seen as inevitable that the renminbi will eventually become a reserve currency. ${ }^{2}$ Here we consider the typical prerequisites for a reserve currency and evaluate China's progress in each of these dimensions. These prerequisites include:

- Economic size: A country's GDP as well as its shares of global trade and finance are important, although not crucial, determinants of its reserve currency status.

- Open capital account: Reserves must be acceptable as payments to a country's trade and financial partners, which requires that the currency be easily tradable in global financial markets. This is difficult if a country imposes restrictions on capital flows and if its foreign exchange markets are thin and subject to the government's direct control.

- Flexible exchange rate: Reserve currencies are typically traded freely and their external value is determined by the market, although this does not preclude occasional bouts of intervention by the country's central bank in foreign exchange markets. It is worth emphasizing that an open capital account is not synonymous with a freely floating exchange rate.

- Financial market development: A country needs to have a broad range of deep and liquid financial markets, especially government bond markets, to provide safe assets that can be held by other countries' central banks. Turnover in these bond markets, which is a measure of liquidity, is also important.

- Macroeconomic policies: Investors in a country's sovereign assets must have faith in its economic policies, especially the commitment to low inflation and sustainable levels of public debt, so the value of the currency is not in danger of being eroded.

This study seeks to provide fresh analytical perspectives on the relative importance of these factors and trade-offs among them. For instance, the Swiss 
franc is a global reserve currency even though Switzerland's shares of global GDP and trade are quite modest. Moreover, many of the major reserve currency economies - the euro zone, Japan, and the United States-have large and rising public debt burdens, which raises questions about their macroeconomic stability but has not (yet) affected their currencies' status as reserve currencies. Some analysts have in fact extrapolated from the U.S. experience to argue that China must run large current account deficits if it wants to provide reserve assets to the rest of the world. But this is neither a necessary nor sufficient condition for attaining reserve currency status.

We begin, in Section 2, by documenting and evaluating the evolution of China's capital account openness in both de jure and de facto terms. These measures together reflect the extent to which broad restrictions on capital inflows and outflows are relaxed through official policy changes or the avoidance of capital controls. This analysis is complemented by a narrative account of measures to open up the capital account as well as an empirical evaluation of how China's capital flows and stocks of external assets and liabilities have evolved during the last decade. Although a number of restrictions on both inflows and, especially, outflows have been loosened in recent years, China still has a substantial capital control regime. In de facto terms, however, its integration into global financial markets has proceeded more quickly.

In Section 3, we analyze the costs and benefits of capital account liberalization for China and how its sequencing relative to other policy changes affects the risk/benefit trade-off. A large literature documents that opening up the capital account without a flexible exchange rate is risky. In addition, the level of domestic financial market development and the composition of a country's external balance sheet also affect the magnitude of these risks. An examination of China's international investment position, both in terms of evolution over time and from a cross-country perspective, suggests that the economy faces only modest risks from a more open capital account in terms of vulnerability to external shocks. The bigger risks may be domestic ones that are related to sequencinga more open capital account can hurt financial stability and constrain monetary policy in the absence of a more flexible exchange rate and a better-developed financial system. There is also a larger debate about the ultimate objectivefree convertibility, which involves minimal restrictions, or full convertibility, defined as unrestricted capital flows but with significant regulatory oversight through reporting and registration requirements (Yam 2011).

In Section 4, we investigate the renminbi's potential to become a global reserve currency. Attaining reserve currency status has both intangible benefits, such as prestige, and tangible ones. A reserve currency earns seigniorage 
revenues from abroad-inflation reduces the value of foreign (and domestic) investors' holdings of the currency-and provides easier access to cheap foreign financing of debt issued in the domestic currency, a privilege that in the case of the United States has been called an "exorbitant privilege." To the extent that this status results in a greater denomination of trade transactions in China's own currency, domestic importers and exporters would face lower currency risk. The potential costs of having a reserve currency include reduced control of the currency's external value and possibly a more volatile exchange rate. This status in principle entails a greater burden of responsibility because domestic monetary policy has more spillover effects to other economies.

We provide an empirical evaluation of the progress China has made, and how it compares with other reserve currency and major emerging market economies, in terms of the prerequisites for attaining reserve currency status. Given China's specific circumstances, we discuss the relative importance of these prerequisites and the dimensions in which China might break the mold. We discuss how factors like greater exchange rate flexibility, deeper financial markets, and interest rate liberalization can promote the process of internationalization of the renminbi while maintaining a favorable benefit-risk trade-off during the transition.

In Section 5, we show that the renminbi is already on the path to ascendance as a global currency. Renminbi trade settlement in Hong Kong has expanded rapidly, the issuance of renminbi-denominated bonds both in Hong Kong and the mainland is picking up, and there are signs that some central banks are considering holding renminbi-denominated assets in their foreign exchange reserve portfolios. These shifts are still modest in terms of their absolute magnitudes and could soon hit their limits unless China's capital account becomes more open.

In Section 6, we review the implications of the increasingly prominent renminbi for the global monetary system, with a particular focus on the implications for the U.S. dollar. We examine trends in the quantity and composition of renminbi-denominated assets and the pace of China's financial development. We then assess the implications of China's capital account convertibility for the pace of its reserve accumulation and its reliance on U.S. dollar assets for these reserves. We also examine different policy measures taken by the Chinese government to diversify foreign assets through purchases of hard assets and investments managed by a sovereign wealth fund, along with encouragement of foreign investment by Chinese corporations and households. This has major implications for discerning future patterns of global financial flows. 
Finally, we discuss the potential inclusion of the renminbi in the special drawing rights (SDR) basket, which currently includes the reserve currencies of four advanced economies. We analyze the economic and political factors that will guide the decision of whether or not to incorporate the renminbi into the SDR basket and highlight the economic and geopolitical implications of this decision.

\section{Openness of the Capital Account}

We begin by evaluating the degree of openness of China's capital account, using both de jure measures of capital account restrictiveness and de facto measures of financial integration. Conventional measures of de jure integration show little, if any, change for China over the past decade. For example, the popular Chinn-Ito index (Chinn and Ito 2008) has not registered any change in China's de jure openness since 1993. Such measures rely on binary indicators from the International Monetary Fund's Annual Report on Exchange Arrangements and Exchange Restrictions (AREAER). These binary measures change only when there is a relatively drastic policy change related to specific capital account items. ${ }^{3}$ By contrast, de facto capital account openness has gone up by leaps and bounds.

\subsection{Capital Controls}

Although de jure measures may not capture changes over time in a country's openness to capital flows, they are still useful as an indicator of the relative degree of openness across economies in a given year. Table 1 shows the ChinnIto index for all the reserve currency economies and several key emerging markets in 1990 (when data are available), 2000, and 2009. ${ }^{4} \mathrm{~A}$ higher value corresponds to a greater degree of de jure openness. The reserve currency economies all have the same index value of 2.48 , which is the maximum and indicates a fully open capital account. The value of the index for China in 2009 is -1.15 , signaling a relatively closed capital account and indicating that China's capital controls are, on paper, quite stringent.

Despite the broad capital account restrictions, the Chinese government has taken a number of steps to ease these restrictions. In 2007, the limit on foreign exchange purchases by residents for remittance abroad for personal reasons was increased to $\$ 50,000$ a year. More recently, the government has been encouraging outflows by institutional investors (e.g., pension funds and insurance companies) and corporations in order to offset some of the pressures for currency appreciation arising from trade surpluses and capital inflows. For 


\begin{tabular}{|c|c|c|c|}
\hline \multicolumn{4}{|c|}{$\begin{array}{c}\text { TABLE } 1 \\
\text { Chinn-Ito Measure of De Jure Financial Openness }\end{array}$} \\
\hline Country & 1990 & 2000 & 2009 \\
\hline United States & 2.48 & 2.48 & 2.48 \\
\hline United Kingdom & 2.48 & 2.48 & 2.48 \\
\hline Switzerland & N.A. & 2.48 & 2.48 \\
\hline Japan & 2.48 & 2.48 & 2.48 \\
\hline Germany & 2.48 & 2.48 & 2.48 \\
\hline Brazil & -1.84 & -1.15 & 0.43 \\
\hline Russia & N.A. & -0.79 & 0.17 \\
\hline South Africa & -1.84 & -1.15 & -1.15 \\
\hline India & -1.15 & -1.15 & -1.15 \\
\hline China & -1.84 & -1.15 & -1.15 \\
\hline
\end{tabular}

Note: This index is calculated from binary dummy variables that reflect a variety of restrictions on cross-border financial transactions reported by the International Monetary Fund, Annual Report on Exchange Arrangements and Exchange Restrictions. N.A. = not available.

Source: Updated version of Chinn and Ito (2008) data set.

instance, in 2009, the government dropped ex ante review and approval requirements for outward remittances of funds for direct investment abroad. Controls on inflows are also being gradually eased, although with many restrictions still in place. The upper limit on portfolio investments by individual qualified foreign institutional investors has been raised but still remains at a modest $\$ 1$ billion, and the period for which these investments are locked up has been reduced.

There are many other subtle or limited changes that are often not captured by standard de jure indexes, which tend to be aggregated across different categories of inflows or outflows. In Appendix A, we provide a detailed documentation of significant changes to capital account restrictions during the past decade, based on annual IMF AREAER reports. The appendix indicates that the number and magnitude of relaxations to capital account restrictions have intensified in the past few years, consistent with the active promotion of the renminbi as an international currency. In most cases, constraints on inflows and outflows have been made less stringent rather than being eliminated entirely.

\subsection{De Facto Openness}

An alternative and complementary approach to evaluating an economy's financial openness is to analyze de facto measures of integration into global financial markets. A standard measure in the academic literature is the economy's gross 
assets plus liabilities position (i.e., its gross external position) in either levels or as a ratio to GDP (see Kose et al. 2009). Figure 1 shows these two measures for China from 2004 to 2010 . The level of its gross external position has grown rapidly, roughly tripling in size over the last five years to more than $\$ 6$ trillion. The ratio of its gross assets plus liabilities to GDP is now greater than one.

Next, we examine the degree of China's financial openness relative to the reserve currency areas and other key emerging markets. In terms of levels, China's gross external position exceeds those of all the other key emerging markets and also Switzerland (Figure 2). As a share of GDP, its openness lags behind those of the reserve currency economies. Among emerging markets, however, China's de facto measure of openness is relatively high, exceeding the levels of countries such as Brazil and India. To the extent that de facto openness is somewhat higher and grows more than the rise in de jure openness, recent steps taken to selectively loosen capital account restrictions do seem to have stoked greater financial flows (see Box 1).

To summarize the evidence from de facto and de jure measures of openness, China still has an extensive capital control regime in place, but it is selectively and cautiously dismantling these controls. Partly as a result of this dismantling, the country's capital account is becoming increasingly open in de facto terms, although even by this measure the degree of China's financial openness is much lower than that of the reserve currency economies.

\section{FIGURE 1}

De Facto Financial Openness in China, 2004-10

A Levels of Gross External Positions

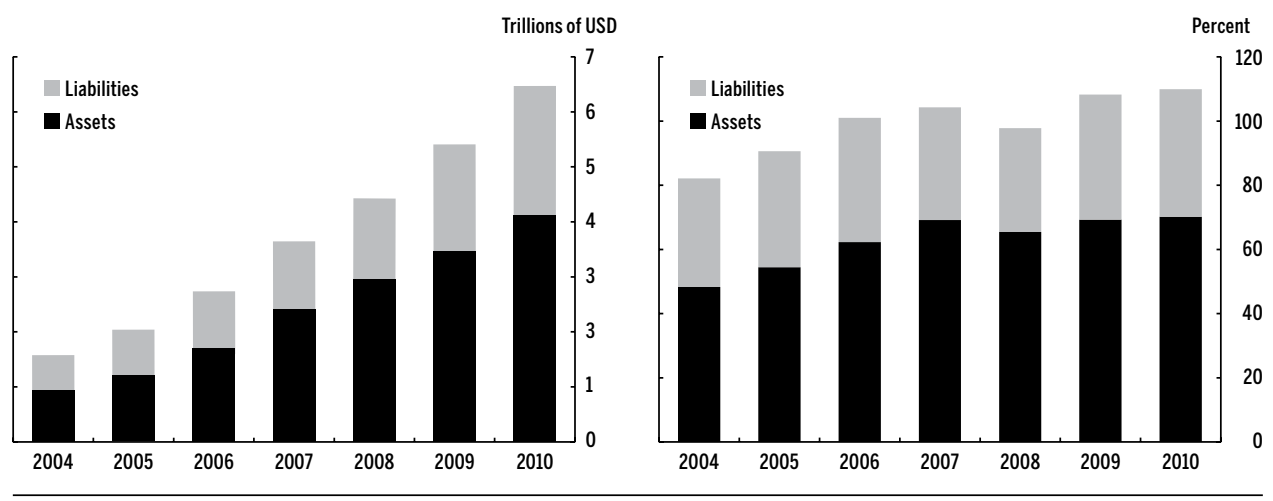

Sources: International Monetary Fund, International Financial Statistics and World Economic Outlook. 
FIGURE 2

\section{De Facto Financial Openness across Economies}

\section{A Levels of Gross External Positions}

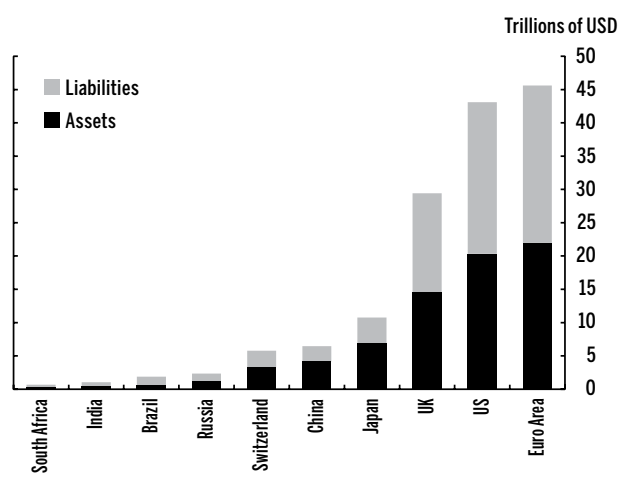

B Gross External Positions as a Share of GDP

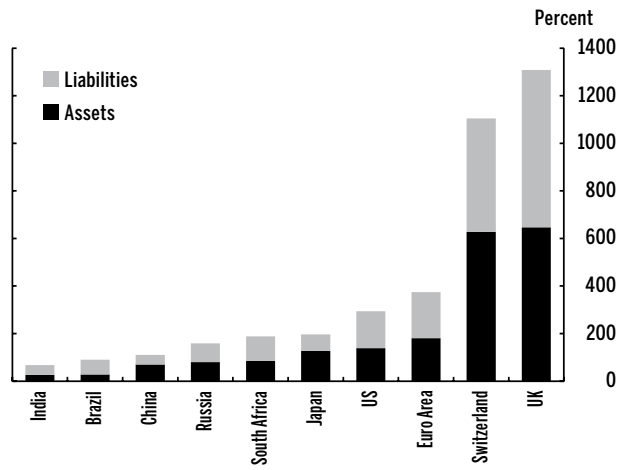

Source: International Monetary Fund, International Financial Statistics and World Economic Outlook.

\section{Sequencing and Cost-Benefit Trade-Offs Related to Capital Account Liberalization}

The literature on financial openness indicates that its potential benefits-both in terms of risk sharing and growth-become apparent only after a country has attained a high level of financial integration. For a country that is in the process of opening up its capital account, there are significant transitional risks if it falls below certain threshold conditions, especially those related to domestic financial and institutional development. A difficult paradox results from the fact that financial opening itself serves as a catalyst for financial market development and improvements in institutions, especially corporate governance. There is no general recipe for how to strike the right balance between these collateral benefits and the risks of premature capital account liberalization (see Kose et al. 2009). The transitional risks cannot be eliminated, but they can be mitigated through supporting conditions such as greater exchange rate flexibility and a more selective approach to capital account liberalization that is designed to attain certain specific collateral benefits (Prasad and Rajan 2008, Prasad et al. 2007).

There is a large literature indicating that opening up the capital account without a flexible exchange rate is risky. ${ }^{5} \mathrm{~A}$ fixed or tightly managed nominal exchange rate makes it harder to cope with capital flow volatility because the exchange rate cannot act as a shock absorber. This combination of policies also reduces the independence of domestic monetary policy, impeding the central bank's ability to use monetary policy instruments such as interest rates to 


\section{$\mathrm{BOX} 1$ \\ Capital Flows and China's Capital Exports to the Rest of the World}

China's capital inflows and outflows have expanded rapidly over the last decade. Gross inflows more than quadrupled from 2000 to 2007 (see column A in the table below). Following a temporary setback during the global financial crisis, inflows surged to $\$ 406$ billion in 2010 , reflecting continued interest in China as a destination for foreign investment. Outflows other than official accumulation of international reserves have also grown substantially, albeit from a low base. Gross outflows fell sharply in 2009 but hit a new high of $\$ 184$ billion in 2010 (column B). Since 2000, accumulation of international reserves has dominated China's overall outflows (column C). From 2000 to 2010, China built up $\$ 2.8$ trillion of reserves, while other gross outflows amounted to about $\$ 845$ billion (including $\$ 219$ billion in outward foreign direct investment, FDI). In other words, about three-quarters of its gross capital outflows were accounted for by official accumulation of reserves. During this period, gross inflows amounted to $\$ 1.8$ trillion, with about twothirds of that ( $\$ 1.1$ trillion) accounted for by gross FDI inflows.

China's overall exports of capital (the sum of official and private net flows) peaked at $\$ 436$ billion in 2008 and then fell by about half in 2009 as reserve accumulation remained strong but other net outflows fell sharply (column E). In 2010, reserve accumulation rose to $\$ 472$ billion and other outflows rebounded sharply to $\$ 184$ billion, but gross inflows strengthened as well, to a historic high of $\$ 406$ billion.

During the period 2000-10, China on net exported about $\$ 1.9$ trillion of financial capital to the rest of the world (by the balance of payments identity, this is the sum of China's current account surpluses over this period).

\begin{tabular}{lccccc}
\hline \multicolumn{5}{c}{ China's Gross Capital Flows, 2000-10 (in billions of U.S. dollars) } \\
\hline Year & A. Gross Inflows & $\begin{array}{c}\text { B. Gross Outflows } \\
\text { (excluding reserves) }\end{array}$ & $\begin{array}{c}\text { C. Reserve Assets } \\
\text { Accumulation }\end{array}$ & $\begin{array}{c}\text { D. Financial } \\
\text { Account Balance } \\
\text { (excluding reserves) }\end{array}$ & $\begin{array}{c}\text { E. Financial } \\
\text { Account Balance } \\
\text { (including reserves) }\end{array}$ \\
\hline 2000 & 58.0 & -56.1 & -10.7 & 2.0 & -8.7 \\
2001 & 41.6 & -6.7 & -47.4 & 34.8 & -12.6 \\
2002 & 50.0 & -17.7 & -75.2 & 32.3 & -42.9 \\
2003 & 67.6 & -14.8 & -137.5 & 52.8 & -84.7 \\
2004 & 104.1 & 6.7 & -189.8 & 110.7 & -79.1 \\
2005 & 183.4 & -86.4 & -251.0 & 96.9 & -154.0 \\
2006 & 212.1 & -163.4 & -284.7 & 48.6 & -236.0 \\
2007 & 262.9 & -170.8 & -460.7 & 92.0 & -368.6 \\
2008 & 170.1 & -126.8 & -479.6 & 43.3 & -436.3 \\
2009 & 201.5 & -24.6 & -400.5 & 176.9 & -223.7 \\
2010 & 405.5 & -184.1 & -471.7 & 221.4 & -250.2 \\
$2011^{\text {a }}$ & 116.5 & -31.8 & -141.2 & 84.7 & -56.5 \\
\hline
\end{tabular}

Note: Gross outflows do not include reserve asset accumulation. The financial account reflects the balance of both official and nonofficial inflows and outflows.

a This is for the first quarter of 2011.

Source: International Monetary Fund, International Financial Statistics. 
maintain domestic price stability. Despite its relatively closed capital account, this constraint applies to China as well because the capital account tends to become porous as interest differentials with the rest of the world increase and the incentives to evade controls become larger (Goodfriend and Prasad 2007). Moreover, if either expectations or fundamentals shift in a way that makes it difficult to sustain the existing level of a managed exchange rate, capital flows could intensify and make the exchange rate harder to manage.

The value of the renminbi is tightly managed against the U.S. dollar, but it was allowed to appreciate gradually against the dollar starting in July 2005. With the onset of the global financial crisis, the hard peg to the dollar was reinstituted before being relaxed again in June 2010. Table 2 provides a cross-country comparison of exchange rate volatility, measured as the standard deviation of changes in monthly exchange rates over the relevant period. The volatility of China's nominal exchange rate against the dollar is the lowest among the major emerging market economies.

To get a broader perspective on de facto exchange rate flexibility, we examine the volatility of the trade-weighted nominal and real effective exchange rates. China's effective exchange rate measures, which tend to track each other closely, are more volatile than the nominal exchange rate. The gap in exchange rate volatility relative to other emerging markets is smaller using these measures, but China still has the lowest level of volatility in this group. In other words, China displays more flexibility in its effective exchange rate, which is ultimately what matters for trade competitiveness. But the tight control of the nominal value of the renminbi relative to the dollar still has the effect of

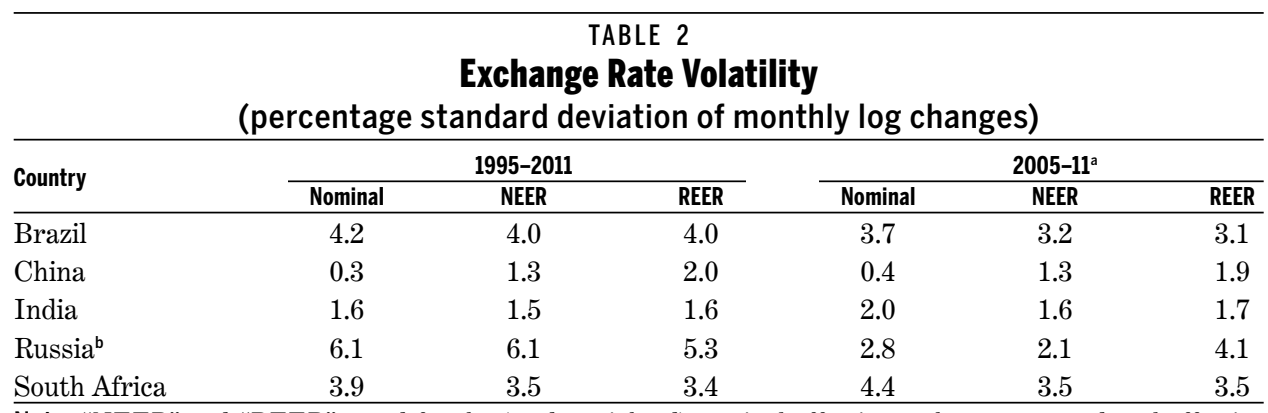

Note: "NEER" and "REER" stand for the (trade-weighted) nominal effective exchange rate and real effective exchange rate, respectively. The NEER for each currency is its monthly period-average exchange rate relative to the U.S. dollar.

a Data for 2011 go through October.

b NEER data for Russia start in July 1995.

Sources: International Monetary Fund, International Financial Statistics; NEER and REER data are from Bank for International Settlements data using broad weights (58 economies). 
hindering the independence of monetary policy and creating other adverse side effects that inhibit the rebalancing of the economy.

Two factors are crucial in determining the magnitude of the risks from an open capital account in the presence of a fixed exchange rate. One is the level of financial development. Broader and deeper financial markets help absorb capital inflows and direct them to productive activities and, more broadly, help to cope with capital flow volatility. We discuss China's financial market development in greater detail later in the paper. The second factor is the structure of a country's capital flows, especially inflows. We now examine this factor.

Figure 3 shows that China's gross capital inflows since 2000 have been mostly in the form of foreign direct investment (FDI). The amount of portfolio inflows and other investments together have traditionally been small, although in 2010 total inflows in these categories exceeded FDI inflows. An examination of China's international investment position confirms that FDI liabilities account for 63 percent of China's total (gross) external liabilities (Table 3). FDI and portfolio

\section{China's Balance of Payment Flows}

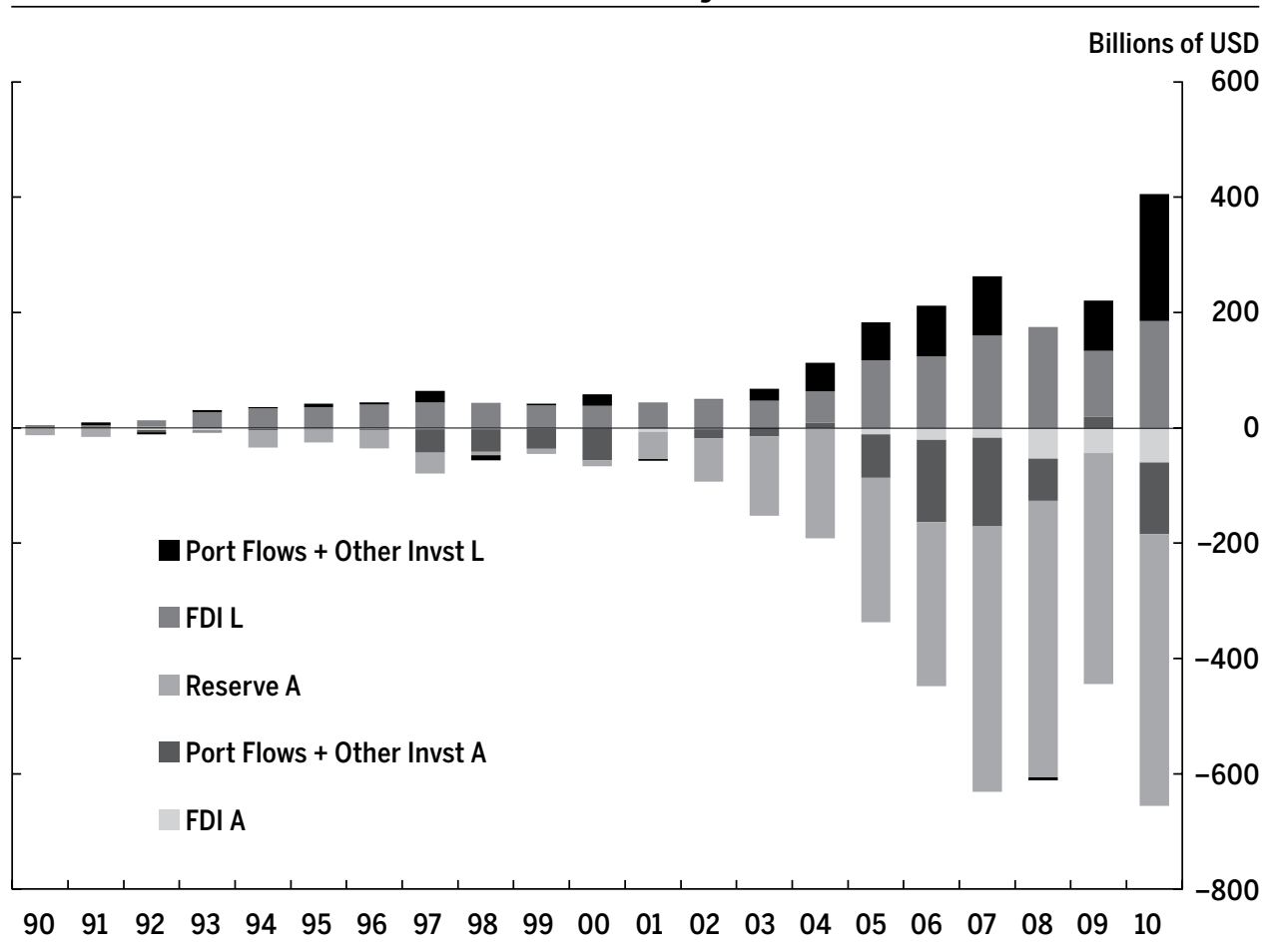


equity together account for 72 percent of external liabilities. FDI is considered the best type of capital inflow because it is stable and often brings with it transfers of technological and managerial expertise. Portfolio equity flows tend to be associated with the collateral benefit of developing and deepening domestic equity markets, but tend to be more volatile than FDI. Nevertheless, this structure of liabilities-dominated by FDI and portfolio equity-is consistent with the objective of sharing risk across countries, with foreign investors bearing capital as well as currency risk on such investment (Kose, Prasad, and Terrones 2009).

Another determinant of external vulnerability for emerging market economies, particularly those with fixed or managed exchange rates, is the level of external debt. Short-term foreign-currency-denominated external debt has been the scourge of emerging markets and was a major source of vulnerability for Latin American and Asian economies during the 1980s and 1990s. China has traditionally had a low level of external debt, and the ratio of external debt to GDP in fact declined from a peak of 18 percent in 1993 to just 8 percent in 2009 (Figure 4). China's external debt level is also low by international standards (Figure 5), suggesting that this is not a source of risk from capital account opening. And of course the stock of foreign exchange reserves of more than $\$ 3$ trillion provides an additional level of insurance.

\section{TABLE 3}

\section{China's International Investment Position}

(in billions of U.S. dollars)

\begin{tabular}{lrrrrrrr}
\hline Aspect of Position & $\mathbf{2 0 0 4}$ & $\mathbf{2 0 0 5}$ & $\mathbf{2 0 0 6}$ & $\mathbf{2 0 0 7}$ & $\mathbf{2 0 0 8}$ & $\mathbf{2 0 0 9}$ & $\mathbf{2 0 1 0}$ \\
\hline Net position & 281 & 413 & 640 & 1,188 & 1,494 & 1,511 & 1,791 \\
A. Assets & & & & & & & \\
Total & 933 & 1,229 & 1690 & 2,416 & 2,957 & 3,457 & 4,126 \\
1. FDI & 53 & 64 & 91 & 116 & 186 & 246 & 311 \\
2. Portfolio & 92 & 117 & 265 & 285 & 253 & 243 & 257 \\
$\quad$ Equity & 0 & 0 & 1 & 20 & 21 & 55 & 63 \\
$\quad$ Debt & 92 & 117 & 264 & 265 & 231 & 188 & 194 \\
3. Other invst. & 166 & 216 & 254 & 468 & 552 & 515 & 644 \\
4. Resv. assets & 623 & 831 & 1,081 & 1,547 & 1,966 & 2,453 & 2,914 \\
$\quad$ FX reserves & 610 & 819 & 1,066 & 1,528 & 1,946 & 2,399 & 2,847 \\
B. Liabilities & & & & & & & \\
Total & 653 & 816 & 1,050 & 1,228 & 1,463 & 1,946 & 2,335 \\
1. FDI & 369 & 472 & 614 & 704 & 916 & 1,315 & 1,476 \\
2. Portfolio & 57 & 77 & 121 & 147 & 168 & 190 & 222 \\
$\quad$ Equity & 43 & 64 & 106 & 129 & 151 & 175 & 206 \\
$\quad$ Debt & 13 & 13 & 14 & 18 & 17 & 15 & 15 \\
3. Other invst. & 227 & 267 & 315 & 378 & 380 & 442 & 637 \\
Source: International Monetary Fund, International Financial Statistics. & & & \\
\hline
\end{tabular}


FIGURE 4

\section{Evolution of External Debt, China, 1990-2010}

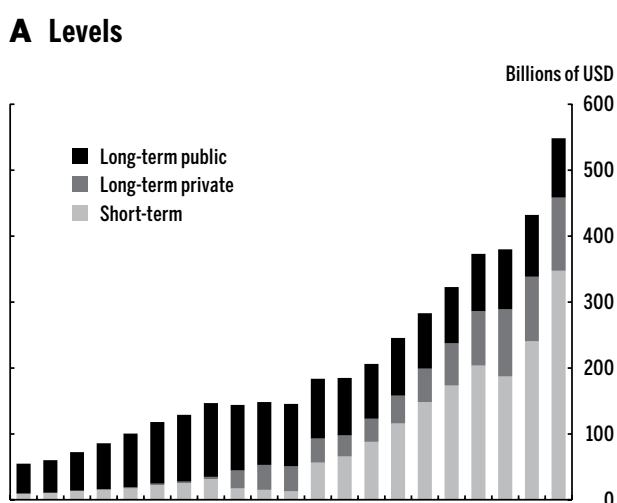

909192939495969798990001020304050607080910
B Ratio to GDP

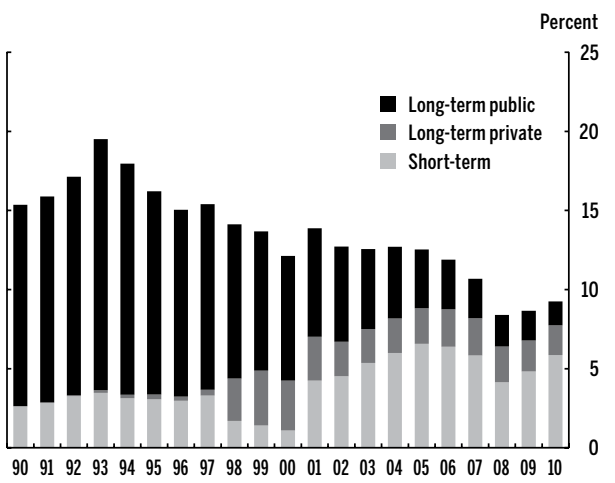

Source: World Bank, Global Development Finance; International Monetary Fund, World Economic Outlook.

\section{FIGURE 5}

\section{Comparative Perspective on Gross External Debt in 2010}

\section{A Levels}

B Ratio to GDP

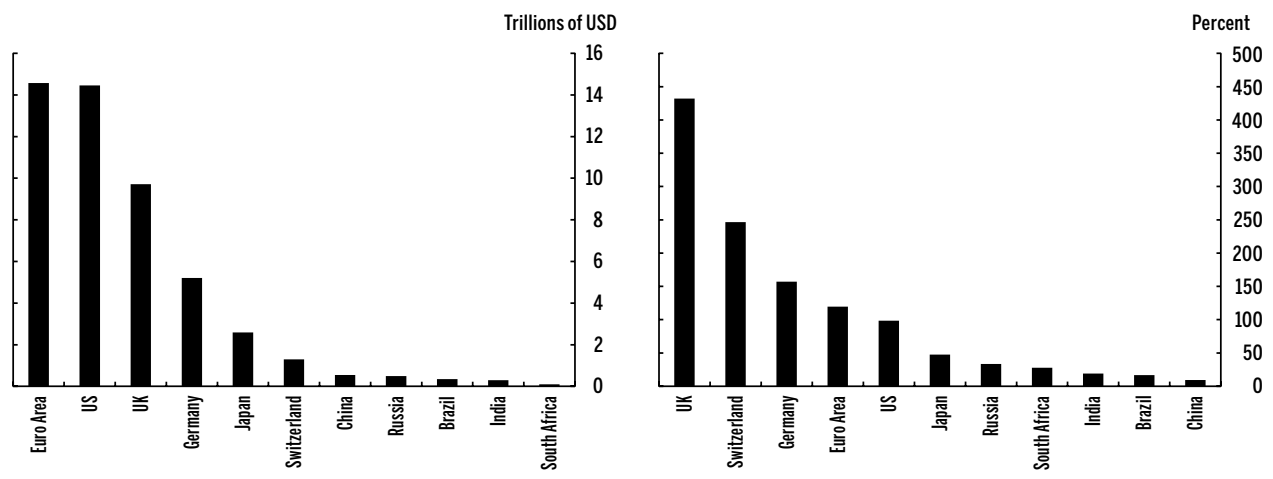

Sources: World Bank, Quarterly External Debt Data and Global Development Finance; Economist Intelligence Unit, country data.

Note: Gross external debt includes those owed by the sovereign, corporate and banking sectors.

Indeed, China's overall external balance sheet shows that its economy is quite well-insulated from external shocks as net foreign assets amounted to nearly $\$ 1.8$ trillion at the end of 2010 . In other words, China has enough foreign assets to not only meet all its external debt obligations but also to more than cover all its foreign liabilities. By contrast, other emerging markets-like Brazil, India, and South Africa-have negative net foreign asset positions, although these are quite small for the latter two countries (Table 4). 
TABLE 4

\section{International Investment Positions in $\mathbf{2 0 1 0}$}

(in billions of U.S. dollars)

\begin{tabular}{lcccccccccrr}
\hline Aspect of Position & $\begin{array}{c}\text { Euro } \\
\text { Area }\end{array}$ & Germany & Japan & $\begin{array}{c}\text { Switzer- } \\
\text { land }\end{array}$ & UK & US & Brazil & China & India & Russia & $\begin{array}{c}\text { South } \\
\text { Africa }\end{array}$ \\
\hline Net Position & $-1,649$ & 1,383 & 3,088 & 786 & -317 & $-2,471$ & -698 & 1,791 & -223 & 16 & -65
\end{tabular}

A. Assets

Total

\section{2,1971}

8,550

6,919

3,285

1. FDI

2. Portfolio

6,277

Equity

Debt

6,466

2,550

1,426

831

911

14,539

20,315

$595 \quad 4,126$

$\begin{array}{lll}410 & 1,173 \quad 304\end{array}$

2,581

,346 1,117

1,675

4,429

175

311

$\begin{array}{lll}94 & 369 & 89\end{array}$

765

679

441

3,240

6,694

$17 \quad 257$

$\begin{array}{lll}2 & 37 & 131\end{array}$

3. Other invst.

3,916

1,817

6,791

3,279

2,667

676

1,159

4,486

$\begin{array}{llll}63 & 2 & 5 & 123\end{array}$

4. Resv. assets

790

217

1,592

802

2,082

2,209

$16 \quad 194$

5
033

8

FX reserves

207

37

5. Fin. derivatives

1,648

1,048

1097

\section{9}

5,984

5,050

489

$115 \quad 644$

52

$281 \quad 2847$

$298 \quad 479$

40

44

$53 \quad 186 \quad 3,563$

3,653

0

\section{B. Liabilities}

Total

1. FDI

2. Portfolio

Equity

Debt

3. Other invst.

23,620

7,167

3,831

2,499

14,857

22,786

\section{$1,294 \quad 2,335$}

$1,076 \quad 2,659$

$\begin{array}{lllll}473 & 1,476 & 198 & 493 & 148\end{array}$

4,967
9,852

3,020

1872

767

$3,939 \quad 11,709$

$656 \quad 222$
430

4,243

590

989

672

1,472

3,510

430

$\begin{array}{lll}206 & 278 & 180\end{array}$

5,608

$\begin{array}{lll}2,430 & 883 \quad 95\end{array}$

2,467

8,199

226

$\begin{array}{llll}206 & 138 & 233 & 138\end{array}$

4. Fin. derivatives

1,708

$2,140 \quad 1,680 \quad 1,005 \quad 6,375$

4,876

161

Source: International Monetary Fund, International Financial Statistics.

The reserve currency economies have diverse net international positions. The United States has a particularly large negative net foreign asset position, amounting to $\$ 2.5$ trillion in 2010. Germany, Japan, and Switzerland have net asset positions, with Japan's position in particular being a massive $\$ 3.1$ trillion. The United Kingdom and the euro area as a whole have negative net asset positions. This diversity suggests that the signs of the net positions are themselves not crucial for reserve currency status. In other words, it is not essential for a country to run persistent current account deficits, as suggested by the Triffin dilemma, for its currency to attain reserve currency status. In fact, the average current account balance as a ratio to GDP during the period 2000-07 was positive (or, in the case of the euro zone as a whole, essentially zero) for all reserve currency economies except the United Kingdom and the United States (Table 5).

In short, China is not subject to the traditional risks associated with opening up the capital account in advance of increasing exchange rate flexibility. Nevertheless, this combination of policies could complicate domestic macroeconomic policy management as a more open capital account with an inflexible exchange rate further erodes the operational independence of monetary policy. 


\begin{tabular}{cc}
\hline \multicolumn{2}{c}{ TABLE 5} \\
$\begin{array}{cc}\text { Average Current Account Balances, 2000-07 } \\
\text { (percentage of GDP) }\end{array}$ \\
\hline Country or Region & Balance \\
\hline Euro area & 0.3 \\
Germany & 3.2 \\
Japan & 3.4 \\
Switzerland & 11.7 \\
United Kingdom & -2.3 \\
United States & -4.9 \\
\hline
\end{tabular}

Sources: International Monetary Fund, World Economic Outlook; authors' calculations.

Moreover, liberalizing capital flows poses significant short-term risks to the financial system if not coupled with appropriate domestic financial reform policies. Liberalizing outflows further without interest rate liberalization could cause households to shift deposits out of the banking sector. The return on those deposits is constrained by the government and has resulted in real rates that are significantly negative. Banking sector earnings are heavily dependent on net interest margins that are mandated by the government through the deposit rate ceiling and lending rate floor (Lardy and Douglass 2011). Hence, massive deposit withdrawals can impose systemically damaging liquidity shocks on the banking sector, with potentially broader macroeconomic repercussions. Related concerns that speculative and volatile capital inflows might destabilize the financial system could be mitigated with a more flexible exchange rate (Eichengreen 2011b). Indeed, the expectations of renminbi appreciation that have resulted from the tight management of the renminbi's value may be fueling more speculative inflows.

The data on the international investment position that we have presented and the combination of policies discussed highlight the major risk for China's external balance sheet, which is in fact the asset position (Prasad 2011). As noted earlier, China's external liabilities are not vulnerable to the valuation changes associated with an appreciating foreign currency, because they are mostly denominated in renminbi. But with foreign exchange reserves accounting for nearly 70 percent of total external assets, the risk comes from valuation losses that would result from the renminbi's eventual appreciation. If the managed exchange rate results in further reserve accumulation through foreign exchange intervention to offset the effects of trade surpluses and capital inflows, then these risks will continue to rise. 
Liberalization of outflows would not only reduce reserve accumulation but would also generate more collateral benefits. Indeed, a number of steps have already been taken in this direction and could be intensified and broadened to involve more private-sector participation. Liberalizing outflows provides Chinese households with opportunities to diversify their savings portfolios internationally and stimulates domestic financial reforms by creating competition for domestic banks that currently have a captive domestic source of funds. Initiatives to encourage corporate outflows have focused on large state-owned firms and a concentrated set of sectors such as natural resources (Scissors 2011; Rosen and Hanemann 2009). For the renminbi to take on a more international role, FDI outflows should involve more participation from the private sector.

The issue of sequencing becomes complex in this context. In the absence of financial market development, the benefits of capital account opening may be limited even if the risks are low, as in the case of China. For instance, Chinese households are in principle allowed to send the equivalent of $\$ 50,000$ a year out of the country, a large amount for an economy with a per capita income of about $\$ 5,000$. But the absence of well-developed securities markets makes it difficult for most households to take advantage of these opportunities to pursue the international diversification of their savings portfolios.

In this context, the liberalization of inflows is an important part of the overall picture. This liberalization would allow foreign investors to play a role in developing and deepening China's financial markets. For instance, there is a large body of evidence that liberalizing portfolio inflows helps improve liquidity in the domestic equity markets of emerging economies. This, along with the entry of foreign banks, would increase competition in the banking sector, which in turn would be beneficial for private savers and borrowers. Other segments of China's financial sector, including the insurance sector, have been dependent on capital controls and other entry restrictions to stay competitive. These segments will face greater competition with more open inflows. With effective regulation, this could lead to significant efficiency gains.

Capital account liberalization could also have broader benefits. An open capital account would catalyze progress toward China's objective of making Shanghai an international financial center. Capital account opening, especially if accompanied by greater exchange rate flexibility, could also strengthen China's domestic economic structure. It would facilitate financial sector reforms, allowing for a rebalancing of growth away from reliance on exports and investment-driven growth, to a more balanced model of growth, with higher private consumption. ${ }^{6}$ 
An interesting issue is whether there is a policy goal short of full capital account convertibility that provides a better risk/benefit trade-off. Yam (2011) has argued that the long-term objective for China ought to be full capital account convertibility, which he defines as relaxation of capital controls but maintenance of soft controls in the form of registration and reporting requirements for regulatory purposes. He draws a careful distinction between this and an entirely unfettered capital flow regime, referred to as free capital account convertibility. This is a subtle but important distinction that may resonate well with the Chinese leadership, given that full convertibility by this definition provides a path to an open capital account without entirely ceding control to market forces.

\section{Evaluating China on Conditions for Attaining Global Currency Status}

In this section, we review China's progress in meeting the criteria thought to be essential for a reserve currency and also provide cross-country perspectives on these indicators.

\subsection{Domestic Financial Market Development}

Financial market development in the home country is one of the key determinants of a currency's international status. ${ }^{7}$ Historically, each reserve currency has risen on the international stage under unique circumstances and spurred by different motivations. But one constant is that this rise has always required financial markets that can cope with the varied and voluminous demands of financial market participants. The relevant aspects of financial market development are the following:

- Breadth: the availability of a broad range of financial instruments, including markets for hedging risk;

- Depth: a large volume of financial instruments in specific markets; and

- Liquidity: a high level of turnover (trading volume).

Without a sufficiently large debt market, the renminbi cannot be credibly used in international transactions. If there is insufficient liquidity in markets for renminbi-denominated assets, the currency will not be attractive to foreign investors. Other central banks and large institutional investors will demand renminbi-denominated government and corporate debt as safe assets for their portfolios. At the same time, both importers and exporters may be concerned about greater exchange rate volatility resulting from an open capital account if they do not have access to derivatives markets to hedge foreign exchange risk. Thus, breadth, depth, and liquidity are all relevant considerations in assessing 
the readiness of a country's financial sector to cope with an open capital account and elevate its currency to reserve currency status.

Furthermore, from a political-economic perspective, a large financial sector helps overcome objections to a more international currency from the exporting sector, which may fear lost competitiveness if demand for the currency as a reserve asset leads to its appreciation. Historical episodes of the rise of international currencies such as the dollar, the mark, and the yen suggest that this factor has in fact played an important role in the past (Eichengreen and Flandreau 2010). In China's case, these pressures may be balanced. The exporting sector indeed benefits substantially from the managed exchange rate but, conversely, China's internationalization of the currency is driven by a national-scale promotion unseen in previous historical episodes (Frankel 2011). This should mitigate any pressures that may arise from exporting interests.

In this section, we assess the progress that China has made in various aspects of financial market development and discuss the close relationship among those reforms, capital account openness, and the international role of the currency. Our main conclusion is that China falls short on many key dimensions of financial market development, and its steps to aggressively promote its currency's international role are likely to be impeded over the medium term by the weaknesses of its financial system.

China's financial system remains bank-dominated, with the state directly controlling most of the banking system. Figure 6 shows that total domestic credit provided by the banking sector, which stood at $\$ 8.8$ trillion as of March 2011 , outweighs the size of the equity and bond markets combined. Domestic credit allocation is still very much controlled by the state and is disproportionately directed toward enterprises, especially state-owned enterprises, rather than households. Table 6 shows the breakdown of total loans from the banking system to the resident and corporate sectors for 2007-10. In these years, the share of loans to the corporate sector remained at roughly 80 percent. Credit allocation through the banking sector is supported by massive deposits in the banking system, amounting to 186 percent of GDP in 2010. This ratio is far higher than that of the other major reserve currency economies, except for the United Kingdom, and also other major emerging market economies (see Figure 7).

The size and structure of the banking sector in China seem unsuitable for promoting the international use of the renminbi on a large scale. Policies that favor the banking sector relative to the rest of the financial system-including the interest rate structure that inhibits competition by setting a floor for lending rates and a ceiling for deposit rates-are detrimental to broader financial 


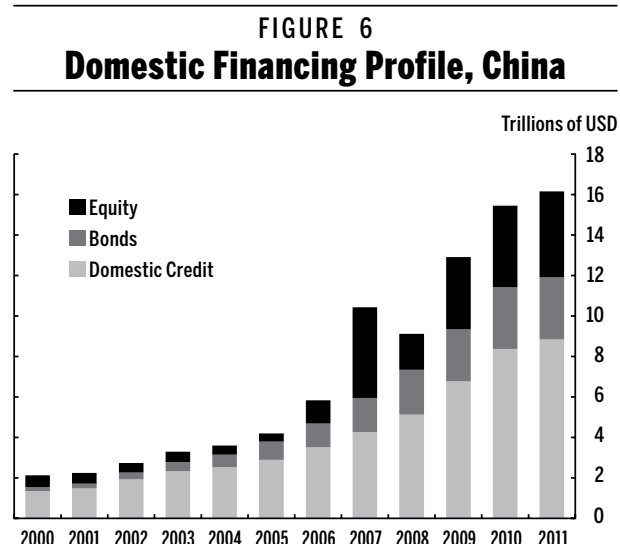

Note: This figure shows the sum of total domestic credit provided by the banking sector, total local currency bonds outstanding and total equity outstanding.

Sources: AsianBondsOnline, Asian Development Bank.

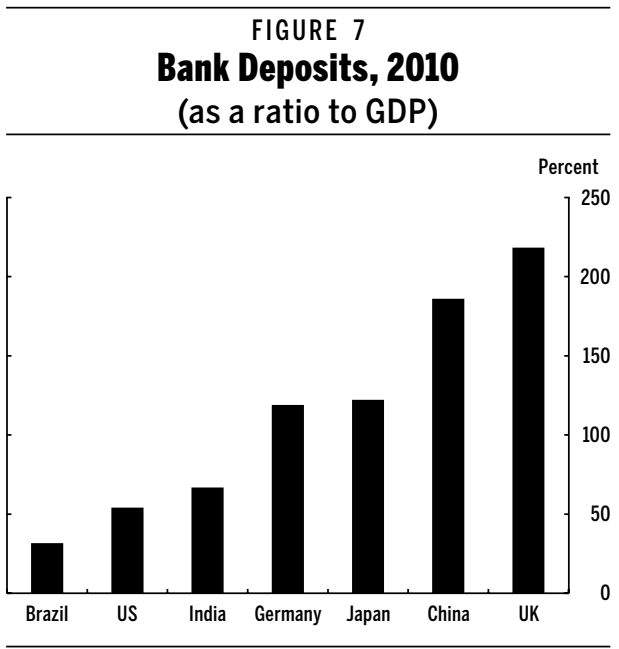

Sources: CEIC; authors' calculations.

TABLE 6

Use of Loans of Financial Institutions in China, 2007-10

(in trillions of U.S. dollars)

\begin{tabular}{lllll}
\hline Use & $\mathbf{2 0 0 7}$ & $\mathbf{2 0 0 8}$ & $\mathbf{2 0 0 9}$ & $\mathbf{2 0 1 0}$ \\
\hline Total & 3.58 & 4.44 & 6.23 & 7.57 \\
Resident/household & 0.69 & 0.83 & 1.20 & 1.70 \\
Nonfinancial corporate & 2.89 & 3.60 & 5.03 & 5.87 \\
\hline
\end{tabular}

Note: End-of-year data were converted from renminbi to U.S. dollars using end-of-period exchange rates.

Source: People's Bank of China.

market development. The future reforms and development of the banking system will have significant implications for the development of China's more nascent financial markets, including the corporate bond market (Hale 2007). The credit distortions in the banking system also hamper the development of a more competitive domestic private enterprise sector. It will be difficult to achieve a liquid debt market without more active participation from private firms as well as households.

One dimension in which China has made progress is the development of its equity markets. In 2005, reforms were introduced to allow nontradable shares in Chinese companies to float freely. These reforms had a dramatic effect. Market capitalization and turnover surged immediately thereafter and have grown sixfold since 2005, while trading volume has climbed more than tenfold (Table 7). Both stock market capitalization and turnover took a big hit in 2008 in absolute 


\begin{tabular}{|c|c|c|c|}
\hline \multicolumn{4}{|c|}{$\begin{array}{c}\text { TABLE } 7 \\
\text { Evolution of Equity Market in China, 2000-2011 }\end{array}$} \\
\hline Year & $\begin{array}{l}\text { Market Capitalization } \\
\text { (billions of U.S. dollars) }\end{array}$ & $\begin{array}{c}\text { Stocks Traded } \\
\text { (billions of U.S. dollars) }\end{array}$ & Turnover Ratio \\
\hline 2000 & 581 & 722 & 1.58 \\
\hline 2001 & 524 & 449 & 0.81 \\
\hline 2002 & 463 & 333 & 0.68 \\
\hline 2003 & 681 & 477 & 0.83 \\
\hline 2004 & 640 & 748 & 1.13 \\
\hline 2005 & 781 & 586 & 0.83 \\
\hline 2006 & 2,426 & 1,635 & 1.02 \\
\hline 2007 & 6,226 & 7,792 & 1.80 \\
\hline 2008 & 2,794 & 5,471 & 1.21 \\
\hline 2009 & 5,008 & 8,956 & 2.30 \\
\hline 2010 & 4,763 & 8,030 & 1.64 \\
\hline $2011^{\mathrm{a}}$ & 3,650 & - & - \\
\hline \multicolumn{4}{|c|}{$\begin{array}{l}\text { Note: The turnover ratio is defined as the value of stocks traded during each } \\
\text { year divided by the average market capitalization between the end of the } \\
\text { current and previous years. Data include both the Shanghai and Shenzher } \\
\text { stock exchanges. }\end{array}$} \\
\hline \multicolumn{4}{|c|}{ a Data are through November. } \\
\hline
\end{tabular}

terms and relative to GDP, as a result of the global financial crisis (Figure 8). Both measures rebounded sharply in 2009 before declining modestly in 2010 . As of 2010, capitalization and turnover in Chinese equity markets exceeded those of other individual economies - with the notable exception of the United States, which remains dominant in terms of its share of global equity market capitalization and turnover (Table 8). Although equity markets do in principle provide renminbi-denominated instruments that can be held by both domestic and foreign investors, there are still significant restrictions on foreign investors' participation in these markets. Moreover, Chinese stock markets are volatile and prone to concerns about governance. For these reasons, the country's deep equity markets may be of limited help in making the renminbi an international currency in the near future.

Next, we examine the current state of the debt market in China and how well-prepared it is for supporting the renminbi's role as an international currency. Figure 9 shows that the stock of domestic debt securities has risen sharply during the last few years, but from a very low base. Nonfinancial corporate debt was practically nonexistent until 2005 . Table 9 shows that the turnover in both government and corporate debt markets has also risen sharply in recent years. 


\section{Equity Markets in China, 2000-10}

(percentage of GDP)

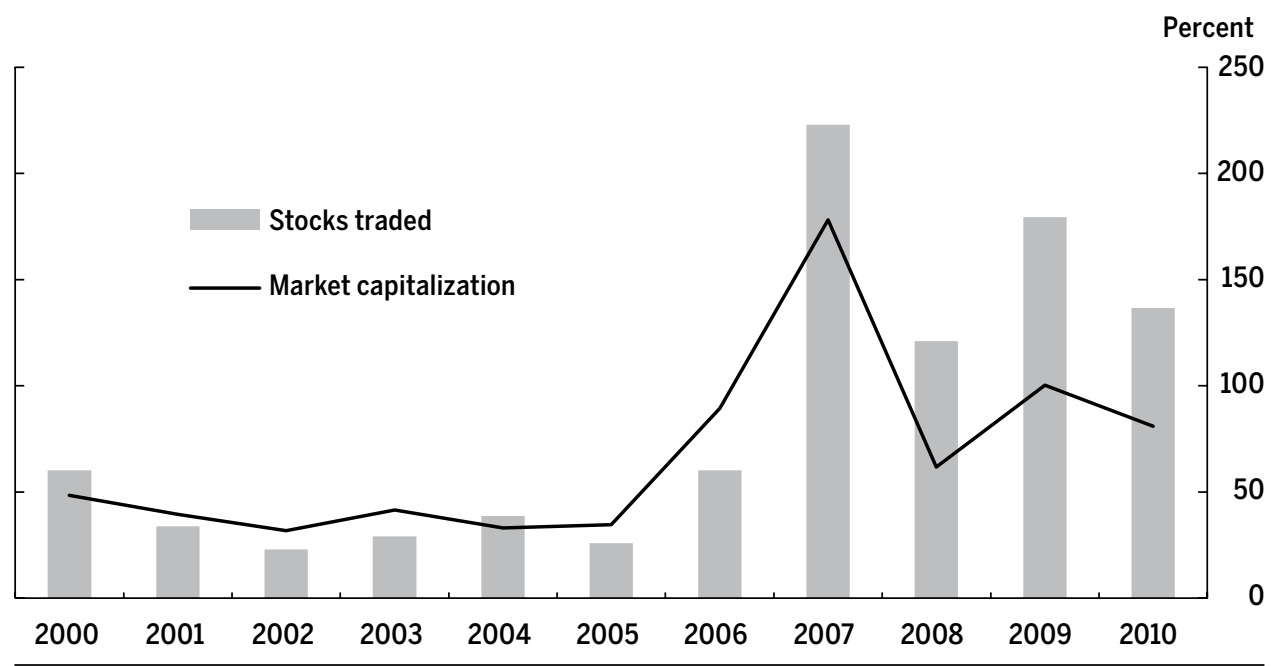

Note: Data include both the Shanghai and Shenzhen stock exchanges.

Source: World Bank, World Development Indicators.

TABLE 8

Equity Markets across Countries in 2010

\begin{tabular}{lccccccccccc}
\hline Aspect & Brazil & China $^{\text {a }}$ & $\begin{array}{c}\text { Euro } \\
\text { Area }\end{array}$ & Germany & India & Japan & Russia & $\begin{array}{c}\text { Switzer- } \\
\text { land }\end{array}$ & $\begin{array}{c}\text { South } \\
\text { Africa }\end{array}$ & $\begin{array}{c}\text { United } \\
\text { Kingdom }\end{array}$ & $\begin{array}{c}\text { United } \\
\text { States }\end{array}$ \\
\hline $\begin{array}{l}\text { Market } \\
\begin{array}{l}\text { capitalization } \\
\text { (billion dollars) }\end{array}\end{array}$ & 1,546 & 4,763 & 6,277 & 1,430 & 1,616 & 4,100 & 1,005 & 1,229 & 1,013 & 3,107 & 17,139 \\
$\begin{array}{l}\text { Stocks traded } \\
\text { (billion dollars) }\end{array}$ & 901 & 8,030 & 4,656 & 1,405 & 1,057 & 4,280 & 800 & 869 & 340 & 3,007 & 30,455 \\
Turnover ratio & 0.66 & 1.64 & 0.75 & 1.03 & 0.76 & 1.14 & 0.86 & 0.76 & 0.40 & 1.02 & 1.89 \\
\hline
\end{tabular}

Note: The turnover ratio is defined as the value of stocks traded during each year divided by the average market capitalization between the end of the current and previous years.

a Data for China include both the Shanghai and Shenzhen stock exchanges.

Source: World Bank, World Development Indicators.

By most measures, the size and liquidity of China's debt market currently lag far behind those of existing reserve currency economies. Table 10 provides a broad comparison of government and corporate bond market size and turnover in 2010 across a number of key economies. The U.S. debt market remains unrivaled both in terms of depth and liquidity, with the turnover in the Treasury bond market dwarfing the turnover in government debt markets of other major economies. The size of China's government bond market, measured by the market value of the stock of outstanding bonds, was about $\$ 2.4$ trillion at the end of 


\section{Evolution of Domestic Debt Securities, China}

\section{A Levels}

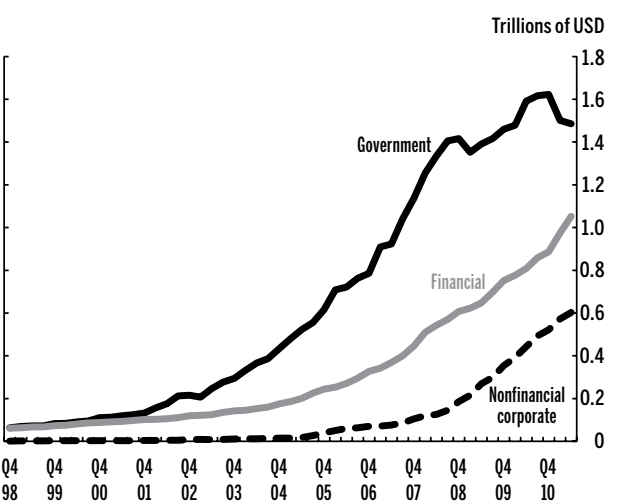

B Ratio to GDP

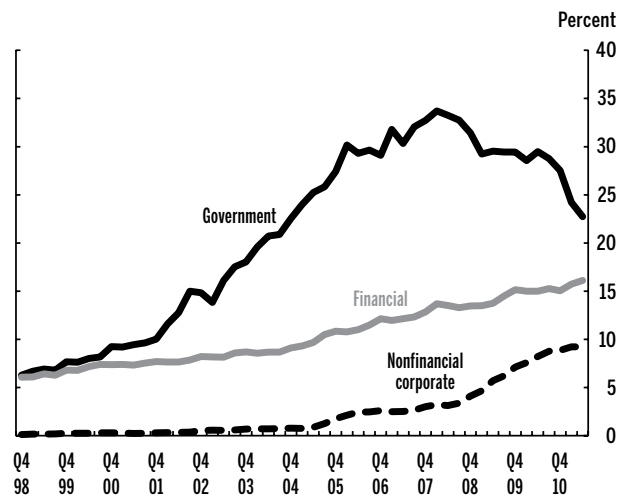

Note: This figure shows data through June 2011. Ratios are calculated using rolling GDP over the past four quarters. Source: Quarterly data from Bank for International Settlements; Economist Intelligence Unit, country data; authors' calculations.

TABLE 9

Turnover of Government and Corporate Bonds, China

\begin{tabular}{lccccc}
\hline \multirow{2}{*}{ Year } & \multicolumn{2}{c}{ Government Bonds } & & \multicolumn{2}{c}{ Corporate Bonds } \\
\cline { 2 - 3 } \cline { 5 - 6 } & $\begin{array}{c}\text { Turnover } \\
\text { (billions of U.S. dollars) }\end{array}$ & $\begin{array}{c}\text { Turnover } \\
\text { Ratio }\end{array}$ & & $\begin{array}{c}\text { Turnover } \\
\text { (billions of U.S. dollars) }\end{array}$ & $\begin{array}{c}\text { Turnover } \\
\text { Ratio }\end{array}$ \\
\hline 2002 & 11 & 0.03 & & 0.3 & 0.04 \\
2003 & 105 & 0.25 & & 0.2 & 0.02 \\
2004 & 97 & 0.17 & & 0.6 & 0.03 \\
2005 & 214 & 0.27 & & 40 & 0.73 \\
2006 & 273 & 0.26 & & 78 & 0.78 \\
2007 & 623 & 0.43 & & 114 & 0.79 \\
2008 & 1,518 & 0.79 & & 213 & 0.91 \\
2009 & 1,170 & 0.57 & & 478 & 1.12 \\
2010 & 2,299 & 0.96 & & 776 & 1.25 \\
\hline
\end{tabular}

Note: Turnover is defined as the value of bonds traded on the secondary market. Turnover ratio is defined as total turnover divided by the average amount of bonds outstanding between the end of the third and four quarters each year. Repurchase transactions are excluded. Corporate bonds include those issued by nonfinancial and financial corporations.

Sources: AsianBondsOnline, Asian Development Bank; authors' calculations.

2010 , compared with $\$ 8.9$ trillion for the United States. The turnover ratio on government bonds in China is 1.0, compared with a ratio of 14.3 for the United States. The turnover of government bonds in India is also roughly twice that in China, although the absolute size of India's government bond market is much smaller. ${ }^{8}$ Both these countries restrict foreign investors' participation in their government bond markets, an issue that could affect their two currencies' scope to become reserve currencies. 
TABLE 10

\section{Government and Corporate Bond Turnover, 2010: A Cross-Country Perspective} (billions of U.S. dollars or ratio)

\begin{tabular}{lcccccccc}
\hline \multirow{2}{*}{ Country } & \multicolumn{3}{c}{ Government } & & \multicolumn{3}{c}{ Corporate } \\
\cline { 2 - 3 } \cline { 7 - 9 } & $\begin{array}{c}\text { Amount } \\
\text { Outstanding }\end{array}$ & Turnover & $\begin{array}{c}\text { Turnover } \\
\text { Ratio }\end{array}$ & & $\begin{array}{c}\text { Amount } \\
\text { Outstanding }\end{array}$ & Turnover & $\begin{array}{c}\text { Turnover } \\
\text { Ratio }\end{array}$ \\
\hline United States & 8,853 & 126,756 & 14.3 & & 7,519 & 3,922 & 0.5 \\
Euro area & 7,926 & - & - & & 5,536 & - & - \\
Germany & 1,400 & 7,834 & 5.6 & & 335 & - & - \\
China & 2,388 & 2,299 & 1.0 & & 620 & 776 & 1.3 \\
Japan & 10,480 & 12,076 & 1.2 & & 1,107 & 76 & 0.1 \\
India & 520 & 1,155 & 2.2 & & 191 & 141 & 0.7 \\
\hline
\end{tabular}

Note: The amounts of government and corporate bonds outstanding and their turnover are expressed in billions of U.S. dollars. Corporate bonds for China, the euro area, Germany, and Japan include those issued by nonfinancial and financial corporations. No disaggregated information is given for the United States and India.

Sources: U.S. Census Bureau, Statistical Abstract of the United States; Securities Industry and Financial Markets Association; European Central Bank; Bundesbank; Federal Financial Supervisory Authority; AsianBondsOnline, Asian Development Bank; CEIC data; Securities and Exchange Board of India; authors' calculations.

China has a relatively high turnover ratio in its corporate bond market. This is consistent with the rapid growth of the corporate debt market, even though that market is still small in absolute terms, at about one-twelfth the size of the U.S. corporate bond market. It is interesting to note that the market value of outstanding corporate bonds in China is greater than the corresponding figure for Germany and about half that for Japan (in Japan, the turnover ratio on these bonds is very low).

Figure 10 shows the size of the global domestic debt securities market by residence of issuance in December 2010. Although the currency breakdown for domestic debt is not available, sources at the Bank for International Settlements suggest that domestic debt is largely denominated in domestic currency (Committee on the Global Financial System 2007, p. 18). China's domestic debt market is valued at $\$ 3$ trillion, significantly lower than that of the top three reserve currency areas - the United States, the euro area, and Japan. The U.S. domestic debt securities market had a capital value of more than $\$ 25$ trillion. Interestingly, the quantity of China's outstanding domestic securities is greater than that of the United Kingdom and Switzerland, two reserve currency economies. This suggests that the size of the domestic debt market per se does not necessarily prevent the Chinese currency from going global.

China's aspirations to make the renminbi a global reserve currency rest in particular on the pace of development of the government debt market. Obstfeld (2011a) has argued that the Triffin dilemma today is not a current account issue but, rather, a fiscal issue. In a world with mobile capital flows, the accumulation of reserves by other countries does not necessarily imply that the reserve 


\section{Domestic Debt Securities, by Residence and Sector of Issuance, 2010}

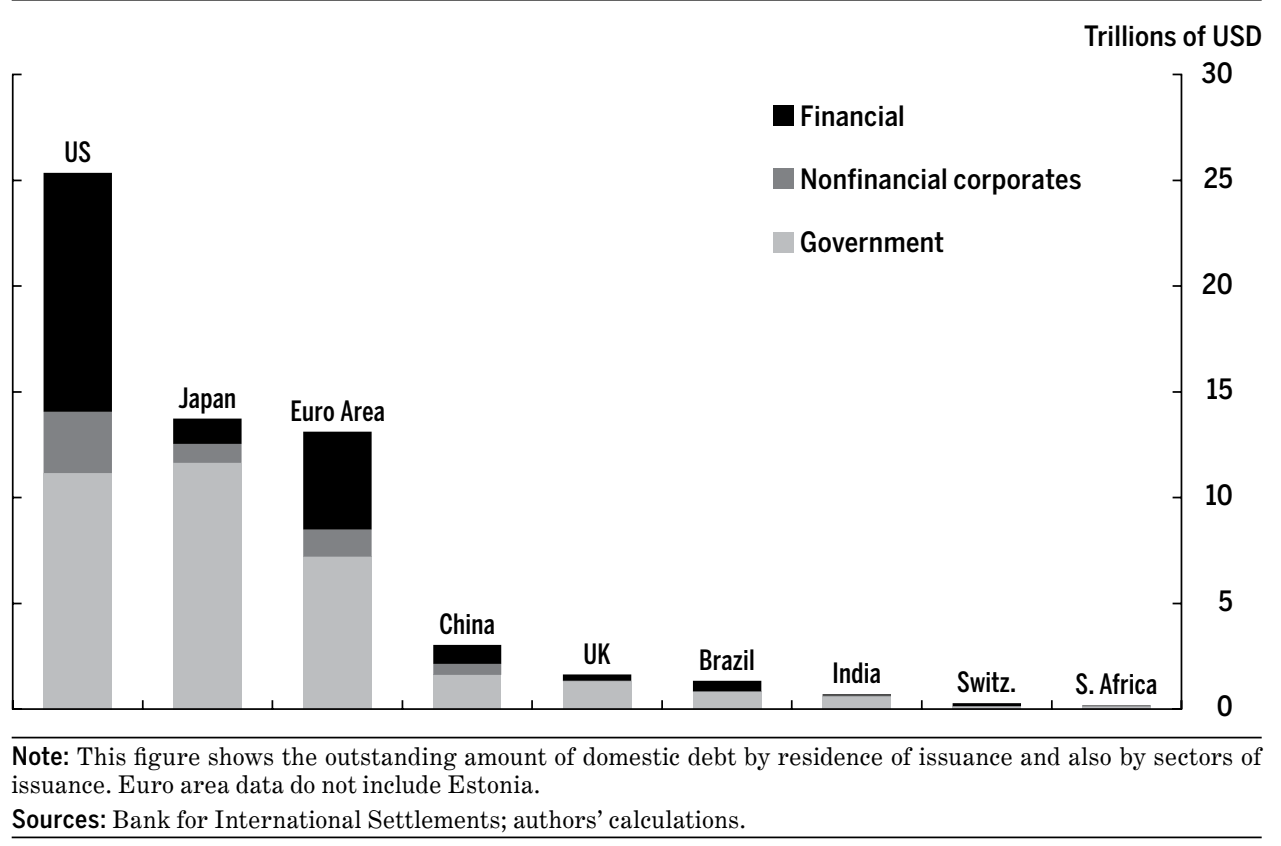

currency economy has to run current account deficits. However, reserve currencies are expected to issue high-quality and creditworthy government debt or government-backed debt instruments that can serve as a hedge against domestic currency depreciation during a global downturn. With a more international renminbi, China is expected to play a more active role in this regard. This implies that government debt in China should rise as the currency fills the role of a reserve currency.

The current level of government debt in China is relatively low compared with reserve currency areas and with other major emerging markets (Figure 11). This is an ex ante advantage for China before internationalizing its currency, given that it provides more credibility about the government's fiscal and inflation policies. If the economy moves toward a more flexible exchange rate and pursues a more independent monetary policy, then it will also require a more diversified set of government bonds across the yield curve spectrum to fully implement its inflation and output objectives. Thus, the structure and size of the government debt market are intimately linked not just to how the renminbi progresses as an international currency but also to China's own economic development. 


\section{General Government Debt as a Share of GDP: Major Advanced, Emerging Market Economies}

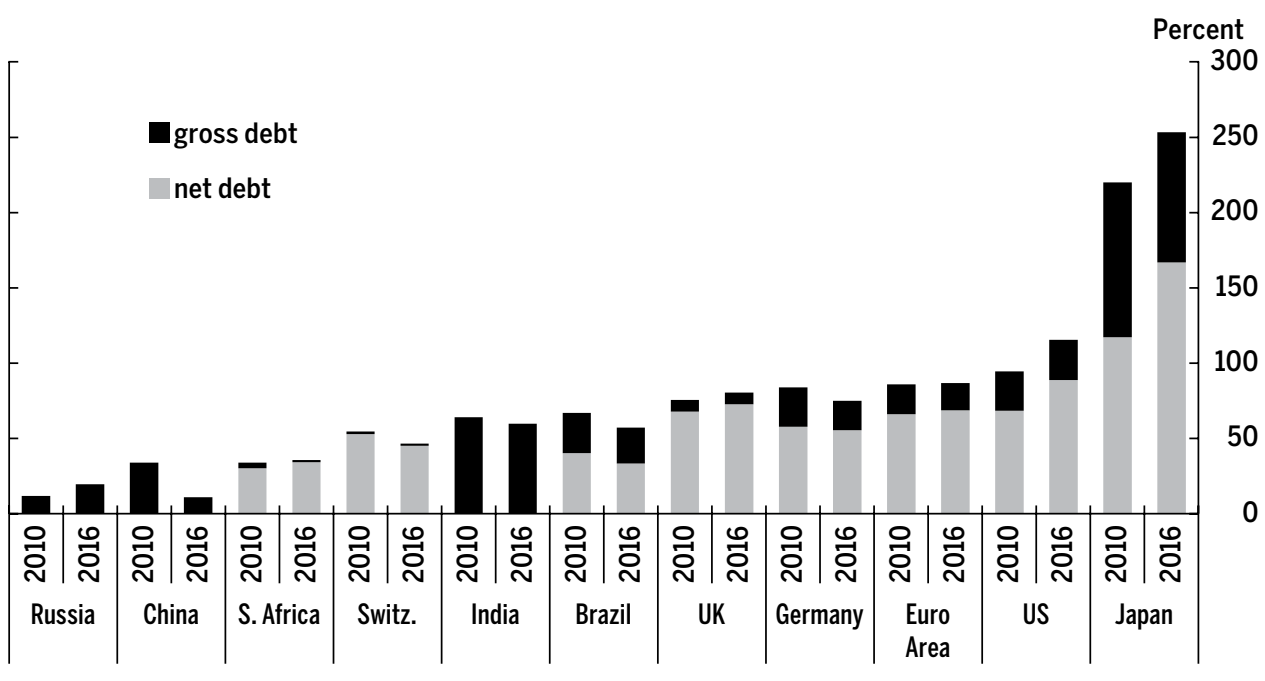

Note: The grey area represents net debt, and the sum of the grey and black areas represents gross debt. Data on net debt for China, India and Russia were not available, and hence only gross debt is shown for these economies. Total 2010 debt data for China include revised International Monetary Fund estimates of local government debt.

Source: International Monetary Fund, World Economic Outlook.

Although the domestic debt market is a major indicator of financial market development, it does not provide a full picture about the currency's potential use in international financial transactions. Hence, we also analyze the relative size of international debt securities (i.e., debt issued outside the home country) in different currencies of issuance. The existing reserve currencies clearly dominate, with the U.S. dollar and the euro accounting for 83 percent of outstanding international bonds and notes in 2010 (Table 11). The top five reserve currencies together account for 96 percent of these instruments. Only a paltry 0.1 percent of international debt is denominated in renminbi. The same is true for other major emerging market currencies. For instance, it is interesting to note that India, another large and fast-growing emerging market aspiring to have a reserve currency, also has a minuscule share of international debt securities denominated in its currency.

Although the absolute size of the debt securities market in China is small from a cross-country perspective, it should not mask the country's rapid growth in these markets. As discussed earlier, domestic debt securities, especially corporate sector debt, were at negligible levels only a decade ago. The domestic debt securities market grew at an average annual rate of 30.3 percent from December 1998 to December 2010 (see Figure 9). Though the outstanding stock 


\begin{tabular}{lcc}
\hline \multicolumn{3}{c}{ TABLE 11 } \\
International Bonds and Notes Outstanding \\
(selected currencies; billions of U.S. dollars)
\end{tabular}

of international bonds and notes issued in China was only $\$ 19$ billion in 2010, this was up from essentially zero in 2005 . The share of nonfinancial corporate debt in total domestic debt outstanding is also rising, accounting for a share of 17 percent and a value of $\$ 522$ billion at the end of 2010. Furthermore, as discussed earlier, turnover in the corporate bond market has grown rapidly since the early 2000 s.

The growth of China's debt markets suggests that the pace of the country's financial market development is consistent with its intention to make its currency accepted as an international currency. Nevertheless, achieving reserve currency status for the renminbi is probably a much longer-term goal. There is some evidence that the ascension of a country's currency to reserve currency status is best approximated by a logistic, rather than a linear, function of the key determinants of achieving that status (Chinn and Frankel 2007, 2008). In other words, the marginal gain toward reserve currency status would be higher if China were to increase its share of world debt markets from, say, 50 to 51 percent rather than from 5 to 6 percent. If this is the correct model for analyzing reserve currency status, then China still has a long way to go in further developing its financial markets to meet the challenges of an international currency.

Overall, there has been progress in the development of China's financial markets during the last decade, in terms of breadth, depth, and liquidity. But this progress remains modest to date. There are still significant gaps to fill in terms of achieving sufficiently large and liquid debt markets. More important, 
the structure and quality of debt markets will also need reorientation to fully prepare for a currency used widely in international financial transactions and reserve holdings. With relatively low external and government debt positions, China's debt markets can in principle expand rapidly without serious threat to inflation credibility or vulnerability to external risks. Effective regulation of corporate debt markets is an important priority so that these markets can expand without generating financial instability. Moreover, to satisfy their demand for relatively safe renminbi-denominated assets, foreign investorsboth official and private-will eventually need to be given greater access to China's debt markets if the renminbi is to become a true international currency.

\subsection{Financial Market Development Related to International Trade and Financial Transactions}

An important criterion for achieving international or reserve currency status is the share of an economy in world trade and its trade interconnectedness with other economies. Although having large trade flows is neither a necessary nor sufficient condition for a country to have an international currency, it does boost the potential for the economy's currency to serve as an invoice currency. This is an underlying implication of Krugman's (1995) triangle model of currency invoicing-whereby economies are more likely to use the currency of the large nation, as measured by trade, due to economies of scale.

Figure 12 shows that Chinese imports and exports have grown dramatically during the past two decades. Trade flows contracted in 2008-09, but have since rebounded and together stood at $\$ 3.2$ trillion, or 54 percent of GDP, in 2010. The value of China's total trade is now only slightly lower than that of the United States (Figure 13). For an economy of its size, China also has a high ratio of total trade to GDP, higher than that of the other key emerging markets and the United States. Table 12 shows that China now accounts for 9 percent of world trade, behind only the shares of the United States and the euro area (figures for the euro area include within-euro area trade). These indicators are suggestive of China's size and rising prominence in world trade.

In addition to trade volumes, another important criterion is the degree to which an economy is interconnected with other economies through trade linkages. This has implications for the incentives of traders in other countries to settle their transactions in the home country's currency. On the basis of a variety of criteria, Errico and Massara (2011) find that, in 2010, China was the second most interconnected country in terms of its trade flows, up from fifth in 2000. China is also ranked second in terms of the size of its trade, giving it the top rank in terms of overall systemic trade importance. The United States 


\section{Imports and Exports of China, 1990-2010}

\section{A Levels}

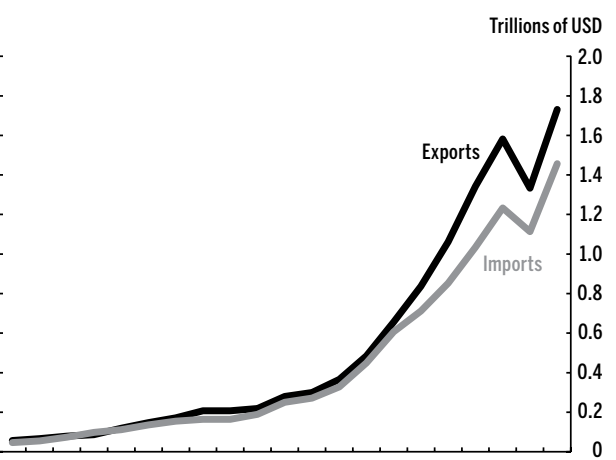

B Ratio to GDP

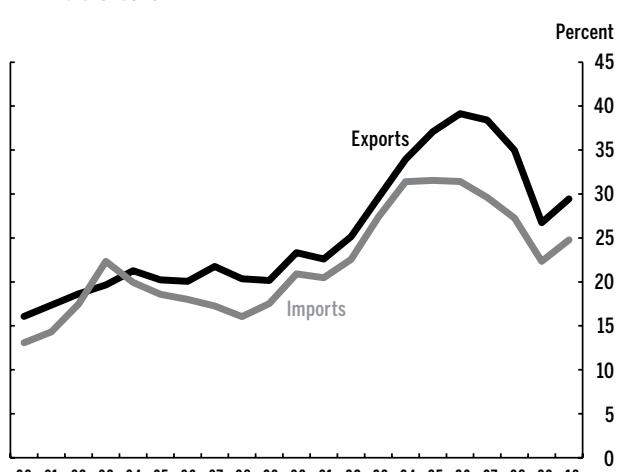

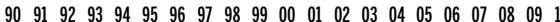

$\begin{array}{lllllllllllllllllllll}90 & 91 & 92 & 93 & 94 & 95 & 96 & 97 & 98 & 99 & 00 & 01 & 02 & 03 & 04 & 05 & 06 & 07 & 08 & 09 & 10\end{array}$

Note: Trade data are for trade in goods and nonfactor services.

Source: World Bank, World Development Indicators.

\section{FIGURE 13}

\section{Trade as a Ratio to GDP across Countries in 2010}

\section{A Levels}

\section{B Ratio to GDP}

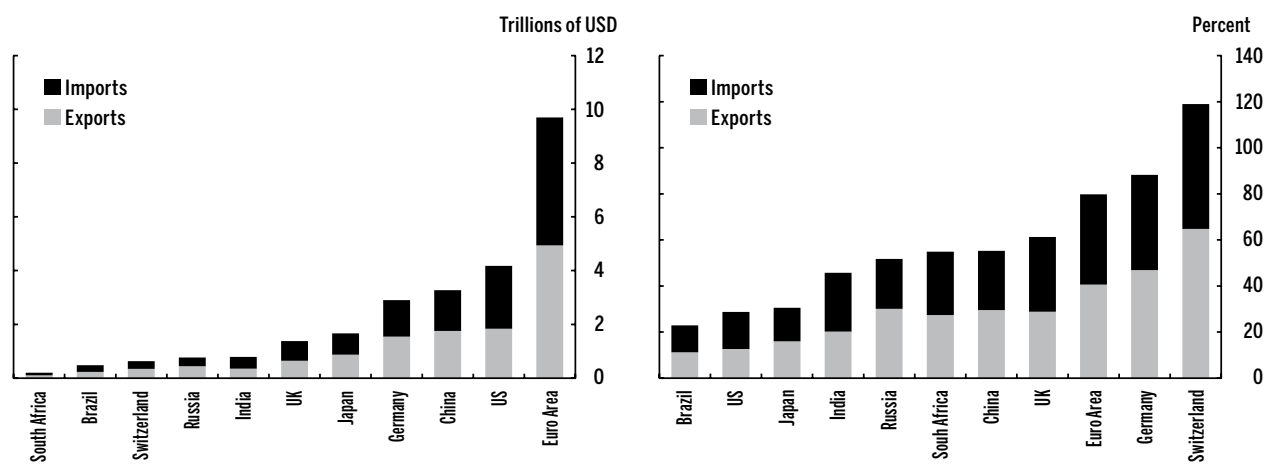

Note: Exports and imports are for trade in goods and nonfactor services. Figures for euro area include withineuro area trade.

Sources: Economist Intelligence Unit, country data; authors' calculations.

ranks first in size and nineteenth in terms of interconnectedness, giving it the rank of sixth in systemic trade importance. ${ }^{9}$

The pace of the internationalization of China's currency depends on its use in international financial transactions as well. The choice of currency for denomination and settlement of trade flows is contingent on the extent to which that currency can also be used in international financial transactions. 


\section{TABLE 12}

\section{Share of World Trade across Economies in 2010 (percent)}

\section{A. Trade in Goods and Nonfactor Services}

\begin{tabular}{|c|c|c|c|c|c|c|c|}
\hline Country or Region & Exports & Imports & $\begin{array}{l}\text { Total } \\
\text { Trade }\end{array}$ & Country or Region & Exports & Imports & $\begin{array}{l}\text { Total } \\
\text { Trade }\end{array}$ \\
\hline Euro area & 26.5 & 26.2 & 26.4 & Euro area & 13.0 & 12.5 & 12.8 \\
\hline United States & 9.9 & 12.9 & 11.4 & United States & 8.5 & 13.0 & 10.7 \\
\hline China & 9.4 & 8.4 & 8.9 & China & 10.5 & 9.2 & 9.8 \\
\hline Germany & 8.3 & 7.5 & 7.9 & Germany & 8.4 & 7.0 & 7.7 \\
\hline Japan & 4.7 & 4.4 & 4.5 & Japan & 5.1 & 4.6 & 4.8 \\
\hline United Kingdom & 3.5 & 4.0 & 3.8 & United Kingdom & 2.7 & 3.7 & 3.2 \\
\hline Russia & 2.4 & 1.8 & 2.1 & Russia & 2.7 & 1.8 & 2.2 \\
\hline India & 1.9 & 2.4 & 2.1 & India & 1.5 & 2.2 & 1.8 \\
\hline Switzerland & 1.8 & 1.6 & 1.7 & Brazil & 1.3 & 1.3 & 1.3 \\
\hline Brazil & 1.3 & 1.3 & 1.3 & Switzerland & 1.2 & 1.1 & 1.2 \\
\hline South Africa & 0.5 & 0.6 & 0.5 & South Africa & 0.5 & 0.6 & 0.6 \\
\hline
\end{tabular}

Sources: Economist Intelligence Unit, country data; International Monetary Fund, International Financial Statistics.

We first examine the renminbi's role in foreign exchange markets. As emerging markets play an increasingly important role in global finance, more international financial transactions will involve direct exchanges of currencies that do not involve the U.S. dollar or other reserve currencies as a vehicle currency. Foreign exchange market turnover is a good indicator of a currency's potential for developing into a vehicle currency. As of 2010, the renminbi accounted for less than 1 percent (out of 200 percent, as each transaction involves two currencies) of all turnover in foreign exchange markets (Table 13). This is true of other emerging market currencies as well. The U.S. dollar is dominant in this dimension, accounting for 85 percent of turnover in 2010. The five reserve currencies together accounted for 162 percent of total turnover.

In terms of the geographic distribution of foreign exchange turnover, however, China has the advantage of having Hong Kong as an important financial center for settling foreign exchange transactions. In 2010, Hong Kong accounted for 5 percent of global foreign exchange market turnover (Table 14). This puts the renminbi on a competitive footing relative to other emerging market currencies in terms of attaining the role of an international currency.

Rather than looking at the foreign exchange market as an aggregate, we can also analyze its various instruments separately. Table 15 shows the shares of average daily turnover in April 2010 in the spot market as well as the markets for outright forwards, foreign exchange swaps, currency swaps, and options and other instruments. Spot transactions make up 24 percent of all foreign exchange 


\begin{tabular}{lcccrr}
\hline \multicolumn{5}{c}{$\begin{array}{c}\text { Currency Distribution of Global Foreign Exchange Market Turnover } \\
\text { (selected currencies only; in percent) }\end{array}$} \\
\hline Currency & $\mathbf{1 9 9 8}$ & $\mathbf{2 0 0 1}$ & $\mathbf{2 0 0 4}$ & $\mathbf{2 0 0 7}$ & $\mathbf{2 0 1 0}$ \\
\hline U.S. dollar & 86.8 & 89.9 & 88.0 & 85.6 & 84.9 \\
Euro & - & 37.9 & 37.4 & 37.0 & 39.1 \\
Deutsche mark & 30.5 & - & - & - & - \\
Japanese yen & 21.7 & 23.5 & 20.8 & 17.2 & 19.0 \\
Pound sterling & 11.0 & 13.0 & 16.5 & 14.9 & 12.9 \\
Swiss franc & 7.1 & 6.0 & 6.0 & 6.8 & 6.4 \\
Indian rupee & 0.1 & 0.2 & 0.3 & 0.7 & 0.9 \\
Russian ruble & 0.3 & 0.3 & 0.6 & 0.7 & 0.9 \\
Chinese renminbi & 0.0 & 0.0 & 0.1 & 0.5 & 0.9 \\
South African rand & 0.4 & 0.9 & 0.7 & 0.9 & 0.7 \\
Brazilian reala,b & 0.2 & 0.5 & 0.3 & 0.4 & 0.7 \\
All currencies & 200.0 & 200.0 & 200.0 & 200.0 & 200.0 \\
\hline Note: The percentage shares of individual currencies sum to 200, because two currencies are involved in each trans- \\
action. Data are adjusted for local and cross-border interdealer double counting (i.e., "net-net" basis). \\
a For 1998, the data cover local home currency trading only. \\
b Included as main currency separately reported by the Bank for International Settlements from 2010. \\
Source: Bank for International Settlements.
\end{tabular}

\begin{tabular}{|c|c|c|c|c|c|c|}
\hline \multicolumn{7}{|c|}{$\begin{array}{l}\text { TABLE } 14 \\
\text { Geographical Distribution of Global Foreign Exchange Market Turnover } \\
\text { (selected economies only; in percent) }\end{array}$} \\
\hline Country & 1995 & 1998 & 2001 & 2004 & 2007 & 2010 \\
\hline Brazil $^{a}$ & - & 0.2 & 0.3 & 0.1 & 0.1 & $\overline{0.3}$ \\
\hline China $^{b}$ & - & 0.0 & - & 0.0 & 0.2 & 0.4 \\
\hline Germany & 4.8 & 4.7 & 5.4 & 4.6 & 2.4 & 2.1 \\
\hline Hong Kong & 5.6 & 3.8 & 4.0 & 4.1 & 4.2 & 4.7 \\
\hline India & - & 0.1 & 0.2 & 0.3 & 0.9 & 0.5 \\
\hline Japan & 10.3 & 7.0 & 9.0 & 8.0 & 5.8 & 6.2 \\
\hline Russia & - & 0.3 & 0.6 & 1.1 & 1.2 & 0.8 \\
\hline South Africa & 0.3 & 0.4 & 0.6 & 0.4 & 0.3 & 0.3 \\
\hline Switzerland & 5.4 & 4.4 & 4.5 & 3.3 & 5.9 & 5.2 \\
\hline United Kingdom & 29.3 & 32.6 & 31.8 & 32.0 & 34.6 & 36.7 \\
\hline United States & 16.3 & 18.3 & 16.0 & 19.1 & 17.4 & 17.9 \\
\hline Total & 100.0 & 100.0 & 100.0 & 100.0 & 100.0 & 100.0 \\
\hline \multicolumn{7}{|c|}{$\begin{array}{l}\text { Note: Data are adjusted for local interdealer double counting (i.e., "net-gross" basis). Estimated coverage of the } \\
\text { foreign exchange market ranged between } 90 \text { and } 100 \text { percent in most countries. }\end{array}$} \\
\hline \multicolumn{7}{|c|}{ a Data for Brazil for 1998 cover only spot transactions. } \\
\hline \multicolumn{7}{|c|}{ b Data for China from 1998 to 2004 cover only spot transactions. } \\
\hline
\end{tabular}


TABLE 15

\section{Currency and Instrument Distribution of Global Foreign Exchange Market Turnover} (percentage shares of average daily turnover in April 2010)

\begin{tabular}{lccccc}
\hline Currency & Spot & Outright Forwards & $\begin{array}{c}\text { Foreign } \\
\text { Exchange Swaps }\end{array}$ & Currency Swaps & $\begin{array}{c}\text { Options and } \\
\text { 0ther Instruments }\end{array}$ \\
\hline U.S. dollar & 35.2 & 11.6 & 47.4 & 1.1 & 4.7 \\
Euro & 44.4 & 9.6 & 39.2 & 1.1 & 5.6 \\
Japanese yen & 39.7 & 15.2 & 36.9 & 0.9 & 7.2 \\
Pound sterling & 41.6 & 10.7 & 43.4 & 0.5 & 3.9 \\
Swiss franc & 36.4 & 7.5 & 50.2 & 0.7 & 5.3 \\
South African rand & 31.7 & 9.9 & 54.3 & 0.5 & 3.6 \\
Russian ruble & 50.6 & 6.3 & 39.7 & 0.5 & 2.9 \\
Indian rupee & 35.8 & 36.1 & 18.0 & 0.1 & 9.9 \\
Brazilian real & 31.3 & 47.3 & 2.9 & 1.4 & 17.1 \\
Chinese renminbi & 23.7 & 41.6 & 19.9 & 0.2 & 14.6 \\
\hline Note: The
\end{tabular}

Note: This table shows, for each currency, the relative shares of its turnover in each of the five categories of global foreign exchange market shown in the columns. Data are adjusted for local and cross-border interdealer doublecounting (i.e., "net-net" basis).

Source: Bank for International Settlements.

transactions in China, a smaller share than for other reserve currency economies or even other emerging markets, all of which have spot transaction shares exceeding 30 percent. Furthermore, China's use of foreign exchange swaps is limited compared with the reserve currency economies, all of which appear to rely heavily on this derivative instrument. By contrast, China and other emerging markets such as Brazil and India rely much more on outright forwards. Outright forwards are more likely to be used as instruments to hedge foreign currency risk, whereas foreign exchange swaps are often used to fund institutions' foreign exchange balances. The relatively higher use of outright forwards probably reflects the simpler goal of hedging against the renminbi's potential future appreciation, rather than more sophisticated forms of foreign exchange risk management.

Table 16 compares the levels of turnover in April 2010 for major currencies across each of these foreign exchange markets. China's currency has the lowest spot transactions turnover among all economies in the group. Its turnover in outright forwards is higher than that of other emerging markets, which is consistent with the data presented earlier. Levels of activity in renminbi foreign exchange swaps, currency swaps, and options markets are also very limited. The renminbi's foreign exchange derivatives trading volume across the board is far smaller than that of the major reserve currencies. It is interesting to note that India's development in these markets appears roughly similar to that of China, though India's foreign exchange spot transaction turnover is somewhat higher. 
TABLE 16

Turnover in Global Foreign Exchange Market, April 2010

(daily averages in billions of U.S. dollars during April 2010)

\begin{tabular}{lrrrrrrrr}
\hline Currency & Spot & $\begin{array}{c}\text { Outright } \\
\text { Forwards }\end{array}$ & $\begin{array}{c}\text { Foreign } \\
\text { Exchange } \\
\text { Swaps }\end{array}$ & $\begin{array}{c}\text { Currency } \\
\text { Swaps }\end{array}$ & $\begin{array}{c}\text { Options } \\
\text { Sold }\end{array}$ & $\begin{array}{c}\text { Options } \\
\text { Bought }\end{array}$ & $\begin{array}{c}\text { Total } \\
\text { Options }\end{array}$ & $\begin{array}{c}\text { Total Foreign } \\
\text { Exchange } \\
\text { Contracts Sold }\end{array}$ \\
\hline U.S. dollar & 1,188 & 392 & 1,600 & 38 & 106 & 101 & 160 & 3,378 \\
Euro & 691 & 150 & 610 & 18 & 57 & 55 & 87 & 1,555 \\
Japanese yen & 300 & 115 & 279 & 7 & 35 & 31 & 55 & 755 \\
Pound sterling & 213 & 55 & 222 & 3 & 13 & 13 & 20 & 513 \\
Swiss franc & 92 & 19 & 127 & 2 & 9 & 8 & 13 & 253 \\
Indian rupee & 14 & 14 & 7 & 0 & 2 & 2 & 4 & 38 \\
Russian ruble & 18 & 2 & 14 & 0 & 1 & 1 & 1 & 36 \\
Chinese renminbi & 8 & 14 & 7 & 0 & 3 & 4 & 5 & 34 \\
South African rand & 9 & 3 & 16 & 0 & 1 & 1 & 1 & 29 \\
Brazilian real & 9 & 13 & 1 & 0 & 3 & 3 & 5 & 27 \\
\hline
\end{tabular}

Source: Bank for International Settlements.

The underdevelopment of the spot and derivatives markets for trading in the renminbi can be attributed to limited market participation. It was not until 2005 that China allowed nonfinancial firms and nonbanking financial institutions to participate in the spot foreign exchange market on a limited basis. Forward transactions were introduced on the China Foreign Exchange Trade System around the same time.

Some other steps to broaden China's financial markets can also be traced back to the mid-2000s. In 2005, China lifted prohibitions against banks trading in equity and commodity-based derivative products. The development of the over-the-counter (OTC) interest rate derivative market followed that, with the first interest rate swaps issued in 2006. As of October 2011, the gross notional amounts outstanding of OTC interest rate derivatives denominated in euros and U.S. dollars were $\$ 93$ trillion and $\$ 86$ trillion, respectively (Table 17). The same measure for the renminbi is about $\$ 389$ billion, less than half the comparable figures even for Brazil and India.

Although most derivatives markets in China are still nascent, the economy does have a major presence in the commodity futures market. For example, as measured by the number of futures/options traded, three of China's commodity futures exchanges were among the top 20 derivatives exchanges in the world in 2010. Using data from the Futures Industry Association, we calculate that the number of contracts traded at the three exchanges is roughly 7 percent of all trades at the 78 exchanges worldwide for which data are reported. Although this is encouraging in terms of broader financial development, it is not clear that a large commodity derivatives market is as useful as, say, a large financial 


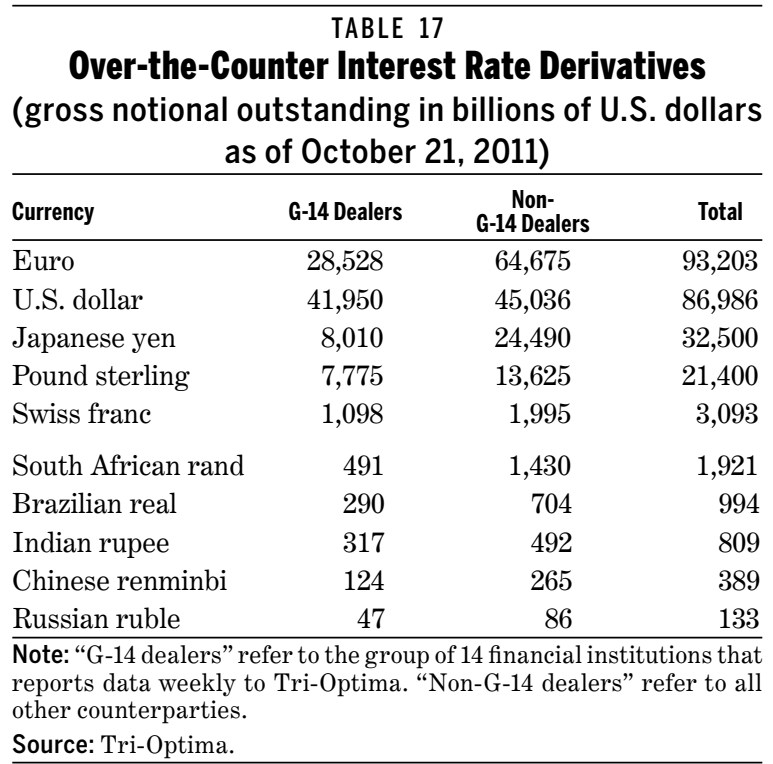

derivatives market, from the perspective of promoting international use of a currency.

The development of a more diverse and liquid derivatives market in China will support a more global renminbi. To some extent, commercial policies that direct activity toward Hong Kong are substituting for some roles that would normally be provided by vibrant domestic financial markets. Figure 14 shows that both the amount of renminbi deposits and the number of institutions authorized to conduct renminbi businesses in Hong Kong rose sharply from October 2010 to October 2011. As the mainland spot and derivatives markets expand in terms of size, liquidity, and access, it will be possible to conduct more of these activities onshore and set the stage for the renminbi to develop as an international settlement currency.

To sum up, thus far commercial policies designed to increase the offshore use of the renminbi have been the centerpiece of China's currency internationalization process. Although this has been effective in promoting the renminbi's global role without risking the potential deleterious effects of capital account liberalization, the full potential of the Chinese currency's international use cannot be realized without more active onshore development. This development would encourage private initiatives to use the renminbi for trade and financial transactions. Ultimately, it will be difficult to fully develop China's foreign exchange and derivatives markets in the absence of substantial capital account liberalization. 
Renminbi Deposits in Hong Kong, January 2005-October 2011

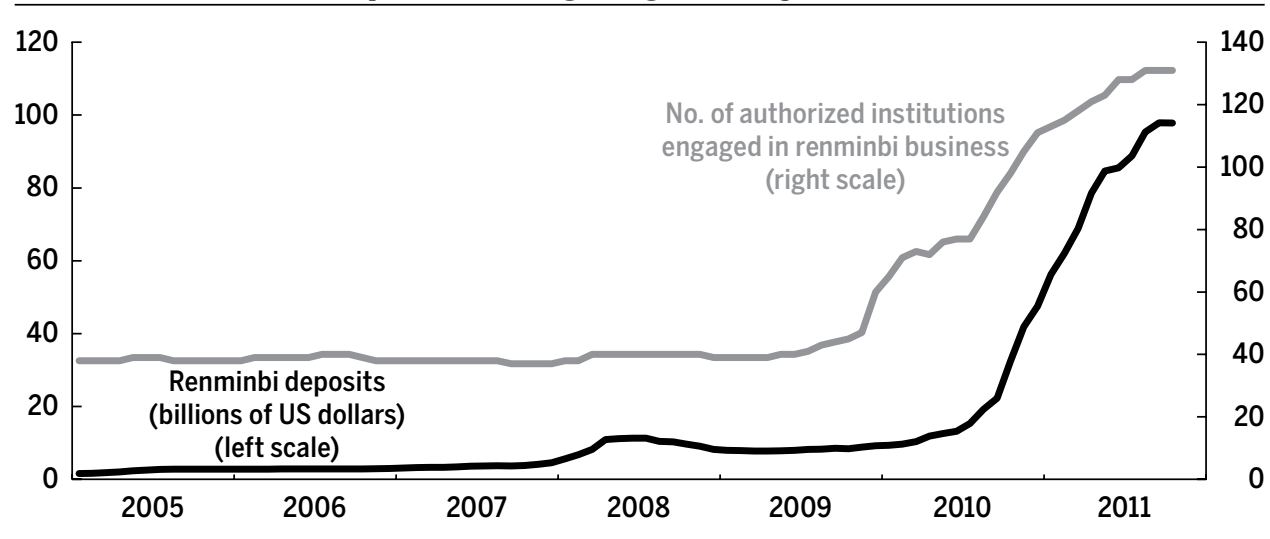

Sources: Monthly data from the Hong Kong Monetary Authority; authors' calculations.

\subsection{Macroeconomic Policies}

A critical attribute of a reserve currency is that it should be "widely acceptable as payment at a predictable value, even when liquidated without notice" (Obstfeld 2011a, p. 3). This implies that macroeconomic policies that anchor long-run inflationary expectations and foster macroeconomic stability are crucial conditions for a reserve currency. As noted earlier, China has a low level of explicit public debt relative to the major reserve currency economies. This is a positive situation from the perspective of macroeconomic stability, even if it means a limited availability of safe renminbi-denominated assets. Moreover, China's general government budget deficit is small-the International Monetary Fund (IMF) estimates that the country's deficit was 1.6 percent in 2011, and it is expected to decline to below 1 percent in 2012. In conjunction with the manageable level of public debt, this implies that China has room to counter domestic and external shocks using fiscal policy.

Despite its tightly managed exchange rate, which has compromised the independence of monetary policy, China has had a relatively stable inflation rate in the recent past. Table 18 shows that the reserve currency economies have had relatively moderate levels of inflation volatility in recent decades, as measured by the standard deviation of annual inflation rates. During the years 2000-10, the period of the Great Moderation followed by the global financial and economic crisis, inflation was well-contained in most major economies. The standard deviations of annual consumer price index inflation in the reserve 


\section{TABLE 18}

\section{Volatility of Annual CPI Inflation (standard deviation)}

\section{A. Reserve Currency Economies}

\begin{tabular}{|c|c|c|c|c|c|c|c|c|c|}
\hline Country or Region & $\begin{array}{l}1970- \\
2010\end{array}$ & $\begin{array}{l}1980- \\
2010\end{array}$ & $\begin{array}{l}1990- \\
2010\end{array}$ & $\begin{array}{r}2000- \\
2010 \\
\end{array}$ & Country & $\begin{array}{l}1970- \\
2010\end{array}$ & $\begin{array}{l}1980- \\
2010\end{array}$ & $\begin{array}{l}1990- \\
2010\end{array}$ & $\begin{array}{r}2000- \\
2010 \\
\end{array}$ \\
\hline Euro area & - & - & 0.6 & 0.5 & Brazil & 572.1 & 640.3 & 668.1 & 2.6 \\
\hline Germany & 2.0 & 1.6 & 1.1 & 0.7 & China & - & 7.8 & 6.6 & 2.1 \\
\hline Japan & 4.8 & 1.8 & 1.3 & 0.7 & India & 5.8 & 3.8 & 4.1 & 3.6 \\
\hline Switzerland & 2.6 & 1.9 & 1.5 & 0.5 & Russia & - & - & 221.0 & 3.8 \\
\hline United Kingdom & 5.4 & 3.1 & 1.8 & 1.3 & South Africa & 4.5 & 4.9 & 4.0 & 3.4 \\
\hline United States & 3.1 & 2.3 & 1.2 & 1.1 & & & & & \\
\hline
\end{tabular}

Note: Euro area inflation volatility is calculated using data for 1999 to 2010. Due to limited data availability, for China and Russia the calculations were done for the periods 1987-2010 and 1993-2010, respectively.

Sources: International Monetary Fund, International Financial Statistics, Global Financial Data.

currency economies were all around 1 percent. During this period, the standard deviations of inflation in emerging markets were in the range of 3 to 4 percent, with China coming in lowest, with a standard deviation of 2 percent. In short, China's track record in terms of the level and volatility of inflation should not be an impediment to its status as a global currency. Indeed, even though the major advanced economies had to deal with occasional bouts of high inflation during the 1970 s and $1980 \mathrm{~s}$, this does not seem to have scarred them in terms of their reserve currency status (Figure 15). One concern, however, is that the People's Bank of China may intrinsically have less credibility vis-à-vis inflation compared with the central banks of the reserve currency economies because its operational independence is constrained by China's managed exchange rate regime. This could become a more serious issue, as discussed earlier, if capital account liberalization proceeds at a fast pace while the exchange rate remains tightly controlled.

\section{The Renminbi's International Presence}

The renminbi is already making its presence felt on the international stage, in part as the result of policy actions by the Chinese government and in part because of the sheer size and growing role of China in international trade and finance. Box 2 provides a summary of the major actions taken by the Chinese government since 2009 to open up its capital account and to promote the international use of its currency. A fuller and more detailed description of all these measures is given in Appendix B. Such a broad and concerted policy of promoting the internationalization of a currency is historically unprecedented (Frankel 2011). In this section, we evaluate the progress that has been made in different dimensions related to the renminbi's ascendance as a global currency. 


\section{Annual Consumer Price Index Inflation Rates of Reserve Currency Economies}

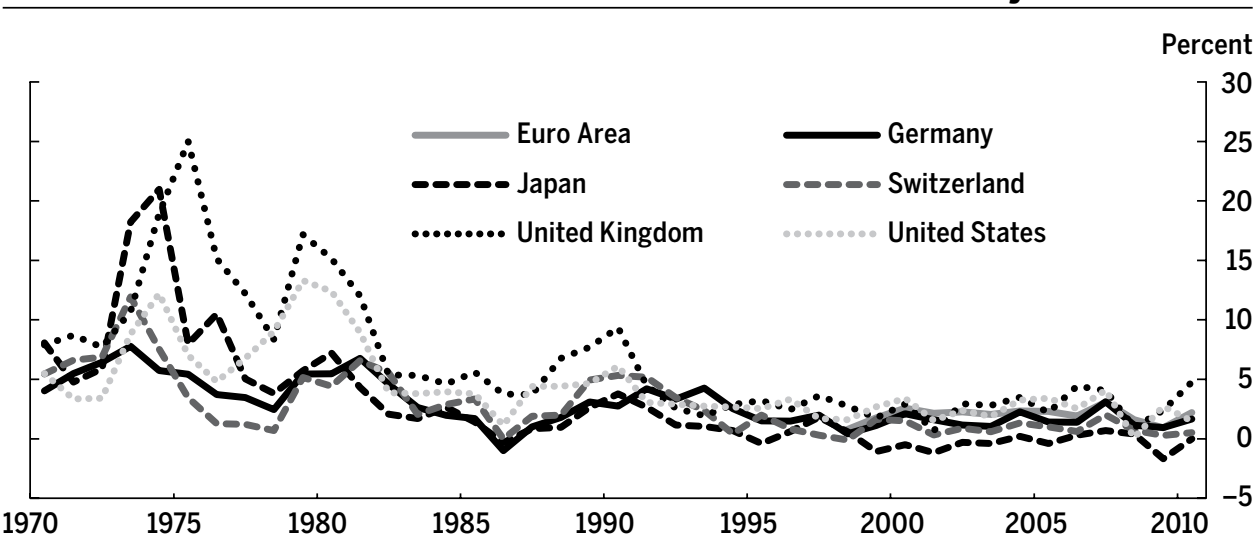

Source: International Monetary Fund, International Financial Statistics, Global Financial Data.

\subsection{Currency Markets}

The renminbi now trades on both onshore $(\mathrm{CNY})$ and offshore $(\mathrm{CNH})$ markets. Onshore trade takes place through the China Foreign Exchange Trade System, which is in effect managed by the People's Bank of China (PBOC). The offshore trades mostly take place on the Hong Kong Interbank Market. Two separate exchange rates prevail due to mainland government regulations that mandate these separate markets for the trading of renminbi. Contrary to the $\mathrm{CNY}$, which is subject to the mainland's capital account restrictions, the $\mathrm{CNH}$ market is relatively less regulated and not subject to direct official control or intervention (Hui and Bunning 2010).

Figure 16 shows the exchange rate of the renminbi against the U.S. dollar on both onshore and offshore exchanges..$^{10}$ Despite the absence of exchange controls on the $\mathrm{CNH}$, the two rates have moved in lockstep for much of the period since the end of 2010 . The two exchange rates became more closely linked after a series of developments in the last quarter of 2010 boosted renminbi-denominated financial transactions. This includes the approval granted to financial institutions and banks in Hong Kong to open renminbi accounts and for Hong Kong banks to access the onshore interbank market; activation of a swap line between the PBOC and the Hong Kong Monetary Authority (HKMA); and a flurry of renminbi-denominated bond issuance activities. These measures have lowered transaction costs for (eligible) financial market participants to access both markets. 


\title{
BOX 2 \\ Summary of Changes to Capital Controls in China and Major Steps Taken to Internationalize the Renminbi (RMB), 2009-11
}

\begin{abstract}
Changes to Capital Controls
August 2009. Review and approval requirements dropped for outward remittance of funds for direct investment abroad. Ex post registration replaces ex ante review for source of foreign exchange for outward direct investment. Certain portion of total outward investment can be remitted, subject to approval by the State Administration of Foreign Exchange, before a foreign project starts.
\end{abstract}

September 2009. Limit on investments by Qualified Foreign Institutional Investors is increased to $\$ 1$ billion, and the principal lock-up period is lowered to three months for pension funds, insurance funds, and open-end funds' medium- and long-term investments and lowered to one year for other institutions.

August 2010. Foreign central banks, Hong Kong and Macao RMB clearing banks, and foreign banks conducting RMB trade settlement clearing are allowed to invest in the Mainland interbank bond market, subject to limits.

\section{Major Steps toward RMB Internationalization}

April 2009. State Council announces pilot program on RMB cross-border settlement in five cities. Commences in July 2009.

September 2009. Ministry of Finance issues the first sovereign RMB-denominated bond in Hong Kong.

November 2009. Interbank Market Clearing House is founded in Shanghai.

March 2010. PBOC and the National Bank of Belarus sign local-currency settlement agreement, the first of its kind with a nonneighboring country.

June 2010. RMB trade settlement program is extended to 20 provinces.

July 2010. Bank of China (Hong Kong) authorized to clear RMB bank notes in Taiwan.

July 2010. Hong Kong financial institutions allowed to open RMB accounts.

July 2010. Hopewell Highway issues the first corporate RMB-denominated bond in Hong Kong.

August 2010. First offshore RMB mutual fund is started.

August 2010. McDonald's issues RMB bonds in Hong Kong, the first by a multinational.

October 2010. Overseas institutions allowed to apply for RMB accounts for trade settlement.

October 2010. Pilot project for deposits of export proceeds abroad launched in four areas.

December 2010. Chinese exporters eligible for cross-border settlement rises from 365 to 67,359 .

January 2011. Residents of 20 provinces and cities are allowed to use RMB for outward FDI.

January 2011. Bank of China allowed to offer RMB deposit accounts in New York City.

August 2011. Cross-border trade settlement in RMB is extended to the whole nation.

October 2011. Banks are allowed to provide settlement services to overseas entities that made

RMB-denominated investments.

November 2011. JP Morgan Asset Management is allowed to create a $\$ 1$ billion RMB-denominated fund under the Qualified Limited Partners Program, making it the largest foreign manager of RMB-denominated fund so far.

Before this period, renminbi-related activities in the offshore market were quite limited, which contributed to a marked deviation of the $\mathrm{CNH}$ exchange rate from that of the CNY-the renminbi was more valuable offshore. The direction of this persistent gap is something of a puzzle. Equally oddly, a deviation of the two exchange rates appears to have resurfaced temporarily during 
FIGURE 16

\section{Onshore and Offshore Renminbi-U.S. Dollar Exchange Rates}

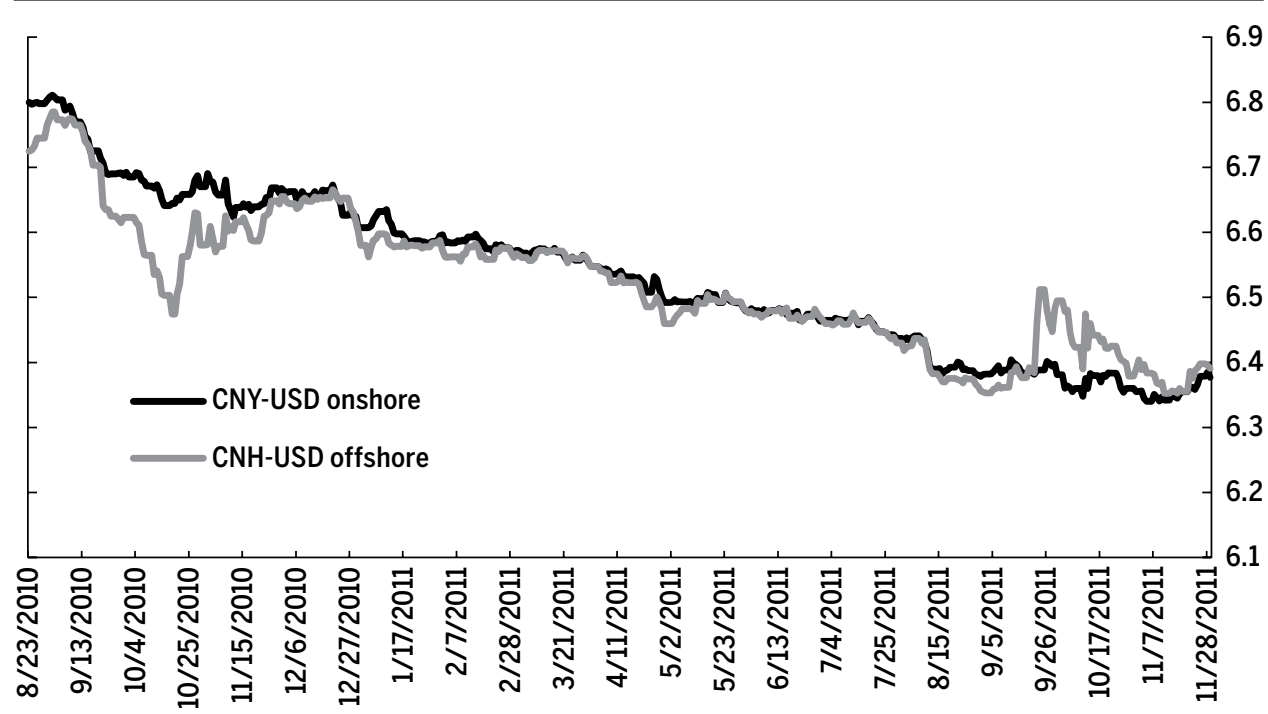

Note: This figure shows the daily midquote exchange rate of the renminbi against the U.S. dollar on onshore (CNY) and offshore (CNH) markets, from August 23, 2010, to November 29, 2011. CNH represents offshore deliverable renminbi. The exchange rate on each nontrading day is that of the previous trading day.

Source: Bloomberg.

the middle of 2011, but this time in the opposite direction-the $\mathrm{CNH}$ exchange rate rose markedly above the CNY exchange rate, and this gap persisted for a while. Although discerning the factors behind the relative movements of these exchange rates is beyond the scope of this paper, the offshore renminbi market and its diversified set of trading environments for the same currency highlight the increasing use of the renminbi in Hong Kong for bond issuance and other financial activities. At the same time, it is a reflection of the unique path that the Chinese government has chosen for internationalizing its currency. Such markets will no doubt contribute to a more global Chinese currency. At present, however, offshore renminbi trading is still restricted by a variety of regulations that limit market participation to a select group-most notably, financial institutions. The extent of the influence of offshore financial transactions on the global use of the renminbi will depend on how these regulations evolve over time.

\subsection{Cross-Border Renminbi Settlement in Hong Kong}

China has a major advantage in undertaking capital account liberalization in a controlled manner-its access to an international financial center, Hong Kong. 
Indeed, Hong Kong has become the testing ground for a number of initiatives to promote the international use of the renminbi. In 2004, personal renminbi business was initiated in Hong Kong by allowing residents there to open deposit accounts denominated in renminbi. Since then, a number of initiatives have been put in place, including allowing cross-border settlements of trade transactions and bond issuances in renminbi.

Given China's rapidly expanding trade volumes, which we documented earlier, promoting a greater use of the renminbi in trade settlement is a logical first step in the currency's internationalization process (Eichengreen 2011b). Figure 17 shows data on cross-border settlements of trade in renminbi since the first quarter of 2010. In a relatively short period, cross-border trade settlement in the Chinese currency has expanded to $\$ 93$ billion (at the end of the third quarter of 2011). During the first three quarters of 2011, renminbi trade settlements amounted to about 8 percent of China's total trade in goods and services.

Data for these settlement transactions broken down by imports and exports are available on a limited basis and indicate that most of the renminbi trade settlement is for imports by China, which allows foreign traders to acquire renminbi. By contrast, there is little settlement in renminbi of China's exports, suggesting that recipients of exports from China either have limited amounts of the currency or are disinclined to reduce their holdings. One interpretation of this one-sided pattern of trade settlements is that it reflects the desire of foreign traders to go long on the renminbi in anticipation of its appreciation and

\section{Cross-Border Renminbi Settlements}

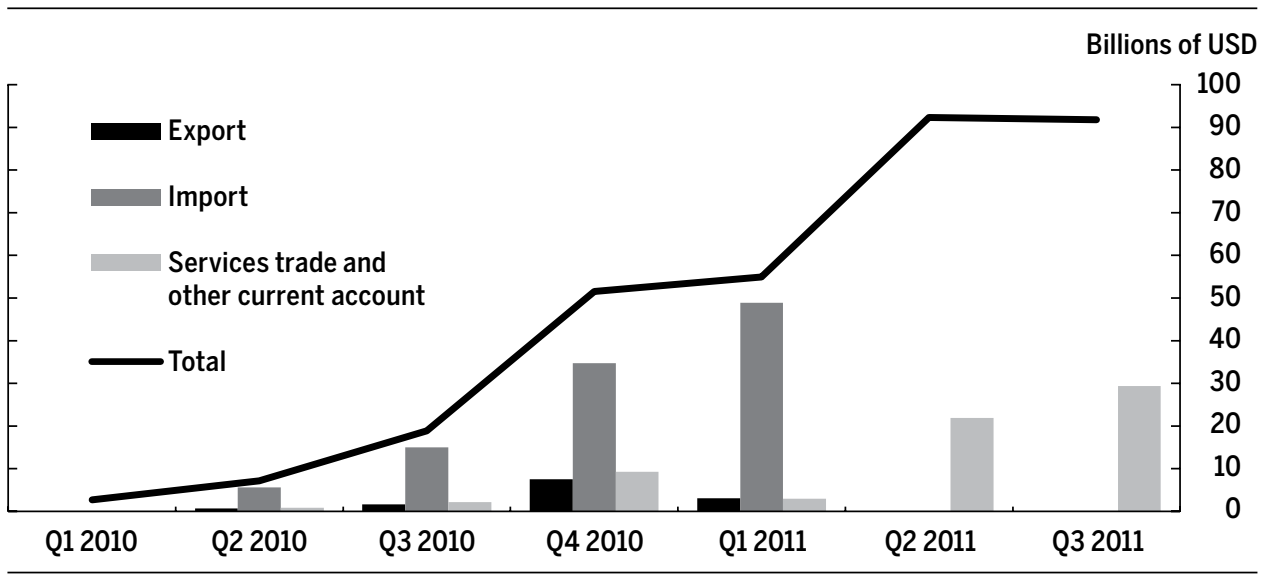

Note: This figure shows quarterly data on cross-border renminbi settlements and the breakdown of this measure by export, import, and services trade and other current account items, when available.

Sources: CEIC; authors' calculations; International Monetary Fund estimates for the fourth quarter of 2010. 
that trade settlement provides one channel for doing so. This is another indication of how China's rising trade and financial integration with global markets will make it increasingly difficult to tightly manage the currency's external value.

Figure 18 provides a complementary perspective by showing the monthly amount of remittances of renminbi used for cross-border settlement in Hong Kong. During 2011, these remittances averaged roughly $\$ 25$ billion per month, more than double the average for 2010. Cross-border renminbi settlement is not confined exclusively to Hong Kong, but its banks play a dominant role. It is estimated that Hong Kong banks handled about 73 percent of China's renminbi trade settlement in 2010 and that this proportion rose to 86 percent in the first quarter of 2011 (HKMA 2011). The geographic coverage for cross-border trade settlement in renminbi has been expanded rapidly during the past two years and was extended to the entire mainland on August 23, 2011.

Another major development is the rising issuance of renminbi-denominated bonds in Hong Kong, otherwise know as dim sum bonds. Panel A of Figure 19 shows that from 2007 to 2010, the issuance of these bonds nearly tripled, to about $\$ 6$ billion in 2010 . In the second quarter of 2011 alone, issuance surged to nearly $\$ 11$ billion, a pace that was sharply higher than in 2010 and that signaled a rapid expansion of these instruments (panels B and C). Issuances fell

\section{Renminbi Remittances: Cross-Border Trade Settlements}

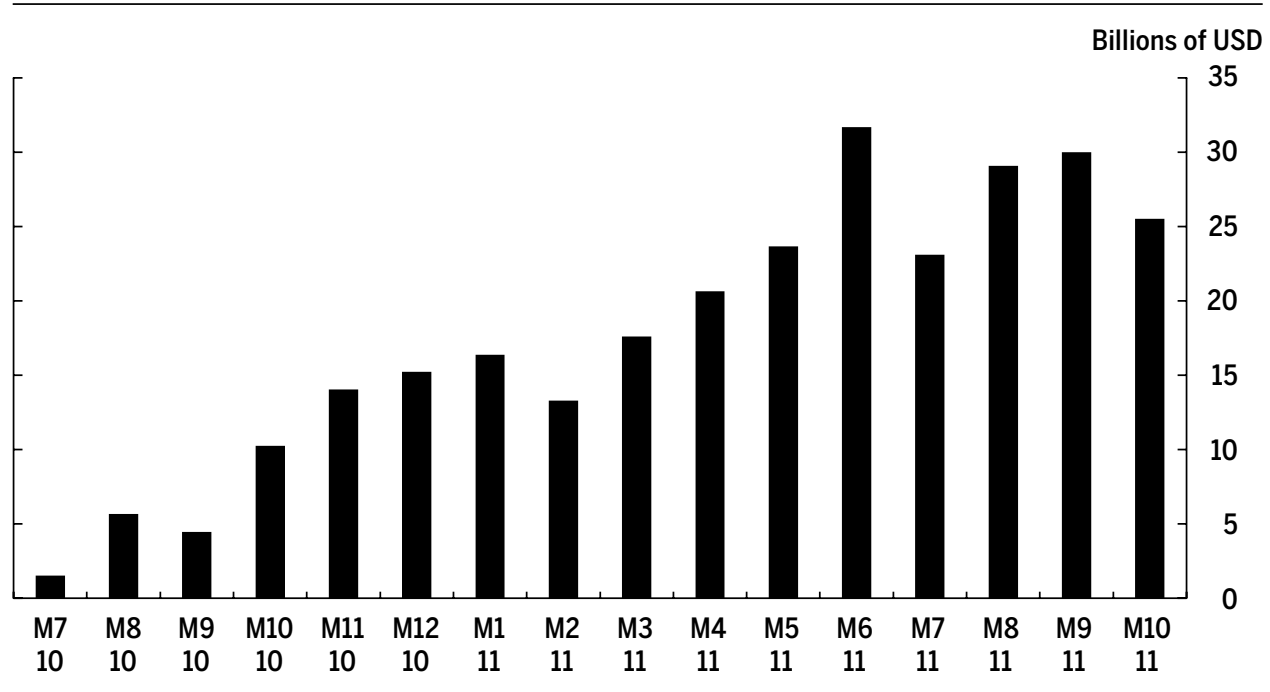




\section{FIGURE 19}

\section{Renminbi Bond Issuance in Hong Kong}

\section{A Annual}

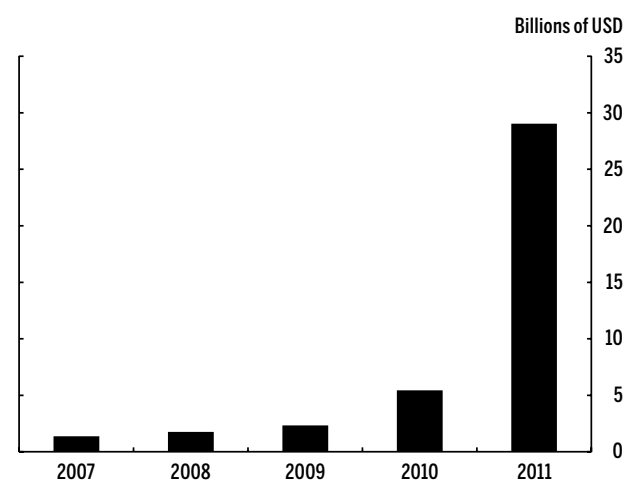

\section{B Quarterly, by Industry of Issuance}

C Quarterly, by Source Country

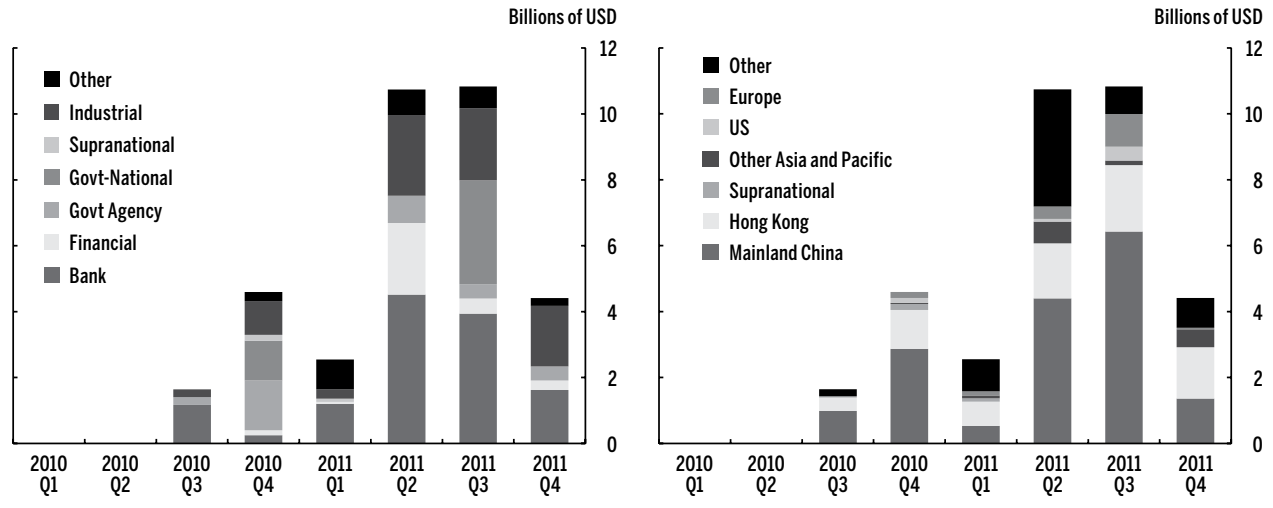

Note: "Government agency" includes state-run policy banks such as the China Development Bank. "Supranational" refers to international economic organizations such as the Asian Development Bank. Data for 2011 represents the latest issuance amount as of scheduled issuance on December 2, 2011. Annual data for 2010 in Panel A are $\$ 5.44$ billion, while the sum of all quarterly data in 2010 for Panels B and C is $\$ 6.24$ billion. This discrepancy is due to different data sources. Panel A utilizes data from the Hong Kong Monetary Authority by way of CEIC. Panels B and C utilize Bloomberg bond database.

Sources: CEIC; Bloomberg.

off in the last quarter of 2011, although it is hard to tell if this signaled a shift in the attractiveness of these bonds for issuers or simply reflected weaker global financial market conditions as the euro debt crisis continued to fester.

An alternative approach to gauging the importance of the offshore use of renminbi is to see how much the currency is used for interbank clearing transactions. After various lines of renminbi business had been started, as discussed earlier, the Hong Kong Interbank Market initiated a renminbi settlement 
system on March 6, 2006, to provide a variety of check clearing, renminbi square position, remittance processing, and bank card payment services. Figure 20 shows that renminbi clearing transactions were virtually zero until mid-2010, when financial institutions in Hong Kong were allowed to open renminbi-denominated accounts. Since then, both the volume and value of transactions have increased dramatically. The total value of transactions hit a peak of nearly $\$ 550$ billion in August 2010, but both transaction volume and value fell in September 2011.

Although the scale remains modest, the initiation and rapid expansion of different elements of the offshore renminbi market are encouraging signs of the currency's prospects of getting a significant foothold in the Asian region's trade and financial transactions. Some caveats are in order, however. First, dim sum bond issuance remains somewhat narrow in scope, in that such issuance is still heavily confined to banking and financial institutions. Second, a large portion of the issuance currently comes from mainland China. These two trends are evident from the breakdowns shown in panels B and C of Figure 19. Third, various reports suggest that a significant portion of cross-border renminbi settlement is used mainly for cross-border arbitrage between mainland China companies and their Hong Kong subsidiaries. ${ }^{11}$ These factors imply that the influence of offshore renminbi use still has some ways to go to reach its full potential.

\section{Renminbi Clearing Transactions: Hong Kong Interbank Market}

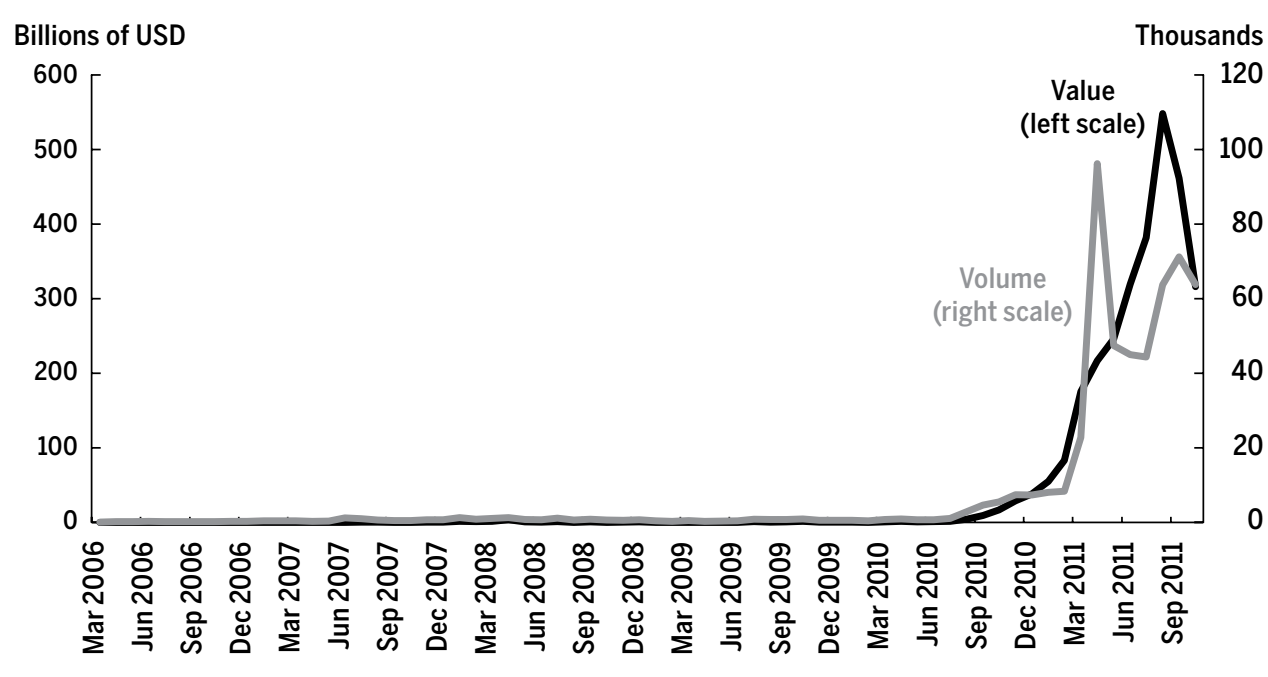




\subsection{The Renminbi Creates Ripples in the Central Banking World}

The PBOC has established a series of bilateral swap lines with other central banks to facilitate and expand the use of the renminbi in international trade and financial transactions. China had in fact established swap lines with other central banks even before it started to actively promote the international use of its currency. Most notably, it had arranged six of them with other Association of Southeast Asian Nations + $3(\mathrm{ASEAN}+3)$ economies under the Chiang Mai Initiative in the early $2000 \mathrm{~s} .{ }^{12}$ Although China established bilateral local currency swap agreements with the Philippines, South Korea, and Japan, most of the other swap arrangements (e.g., the one with Thailand) were dollar-renminbi swaps. Under these arrangements, China would provide U.S. dollars in exchange for the local currency of the counterparty economy..$^{13}$ In other words, the foreign exchange reserves of economies like China would often serve as an additional credit line facility if the counterparty economy were to face a liquidity crunch due to a balance of payments or financial crisis.

Since 2008, China's bilateral swap lines with foreign central banks have directly supported the renminbi's greater international use, though their liquidity-supporting role remains relevant. Appendix $\mathrm{C}$ shows the counterparty, date, and the value of each of these swap lines. In contrast to the norm for previous swap lines, these arrangements are all designed for settlement in local currencies. The amounts of these bilateral agreements have been relatively small so far, no more than the equivalent of $\$ 200$ billion. The extent to which these swap lines have been drawn upon appears to be limited. The HKMA activated its bilateral swap line with the PBOC in October 2010, more than a year and a half after the swap line was set up. At the end of 2010, the amount of bilateral swaps outstanding for the HKMA was 20 billion yuan, or about $\$ 3$ billion (HKMA 2010). The PBOC mentions in its 2010 Annual Report that "at end-2010, overall volume of currency swap agreements reached 803.5 billion yuan. The PBOC also conducted 30 billion yuan of local currency swap operations at the request of a number of monetary authorities" (PBOC 2010, p. 33). This suggests that only 10 billion yuan, about $\$ 1.5$ billion, was drawn outside of Hong Kong. Nevertheless, the PBOC is clearly making an active effort to make the central banks of a broad group of economies comfortable and familiar with renminbi-denominated instruments and financial facilities.

Another noteworthy development is that, despite its lack of convertibility, the renminbi is already beginning to play a modest role in a few central banks' reserve portfolios. Malaysia and Nigeria are widely believed to have pioneered this trend, starting in the second half of 2011. The Central Bank of 
Nigeria issued a statement on September 5, 2011, announcing that it "has finalized arrangements to diversify its external reserves holdings by including the Chinese renminbi (RMB) to the existing currency mix of United States dollars (USD), the euro (EUR) and the British pound sterling (GBP)."14 Furthermore, Chile's internally managed Central Bank investment portfolio now has 0.3 percent of its assets allocated to renminbi-denominated instruments, according to its September 2011 Monetary Policy Report.

Official statements and other accounts suggest that other central banks are also considering adding renminbi assets to their reserve portfolios (see Appendix D). An interesting point is that these holdings cannot in principle be counted as reserves by the IMF, given the present status of the renminbi's (lack of) convertibility. But this does not seem to matter for these central banks, because they view renminbi-denominated assets, just as they do other major reserve currency-denominated assets, as providing insurance against balance of payments pressures. All these moves are modest in size but are symbolically important in signaling the shift in perception about the renminbi's stability and its future role in the international monetary system.

In December 2011, China and Japan signed a pact to promote the use of their currencies for bilateral trade and investment flows. ${ }^{15}$ Trade between the two economies amounted to about $\$ 300$ billion in 2010 , while bilateral financial flows are estimated to be less than $\$ 100$ billion. Assuming that all these transactions are currently settled in dollars and will eventually be settled in the two countries' currencies, the effect on switching from dollar-intermediated transactions would still be relatively modest at the global level. Moreover, given the lack of convertibility of the renminbi, these moves may have a limited impact in the short run. Over time, the effects could be larger, especially because the decline in currency transaction costs and exchange rate uncertainty could boost trade and financial flows between the two countries. China has also given permission for Japan's Bank for International Cooperation to issue a yuan-denominated bond, while Japan has indicated that it will buy some Chinese government bonds, presumably to add to its reserve portfolio. Again, these moves are more important symbolically than quantitatively, but they may be setting the stage for more significant developments as China's capital account becomes more open.

\section{Implications of the Renminbi's Ascendance for the International Monetary System}

The analysis so far has made the point that the renminbi's prospects as a global currency will be shaped by broader domestic policies, especially those related 
to financial market development, exchange rate flexibility, and capital account liberalization. In this section, we discuss the potential impact of the renminbi's rise on the competitive balance among global reserve currencies. We also discuss the effects that the internationalization of the renminbi could have on the structure of global capital flows.

\subsection{Implications of a Rising Renminbi for China-U.S. Financial Flows}

One of the defining statistics in global finance is China's massive stock of foreign exchange reserves, which stood at $\$ 3.3$ trillion at the end of the third quarter of 2011 (Figure 21, panel A). This level of reserves - the equivalent of about 50 percent of China's GDP, and more than all of China's external liabilities combined-is far greater than any level that could be justified on the basis of precautionary reasons. In the last quarter of 2010 and the first two quarters of 2011 , reserve accumulation averaged nearly $\$ 200$ billion each quarter (Figure 21, panel B). This pace fell off sharply in the third quarter of 2011, down to nearly zero, but is expected to pick up again when—or if-global financial markets settle down and the euro zone and U.S. economies begin to recover.

China does not report the currency composition of its foreign exchange reserve holdings, but it is widely believed that about two-thirds are in U.S. dollar-denominated instruments. Data based on the U.S. Treasury International Capital System (TIC) provide at best a partial picture because they track the country of the purchasing agents rather than the owners of U.S. securities.

\section{FIGURE 21}

\section{China's Foreign Exchange Reserves}

A Foreign Exchange Reserve Stocks: First Quarter of 2005-Third Quarter of 2011

Billions of USD

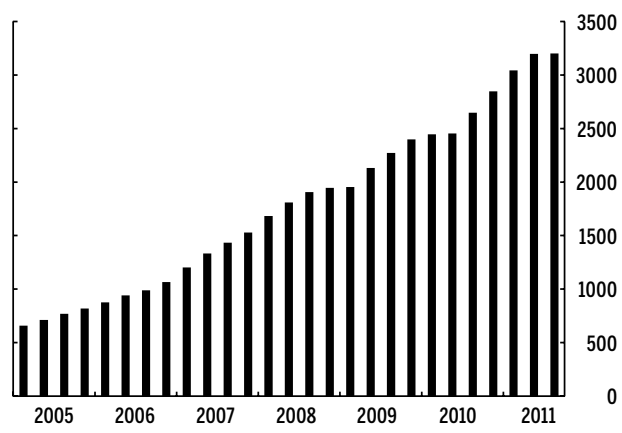

B Accumulation of Foreign Exchange Reserves:

First Quarter of 2005-Third Quarter of 2011

Billions of USD

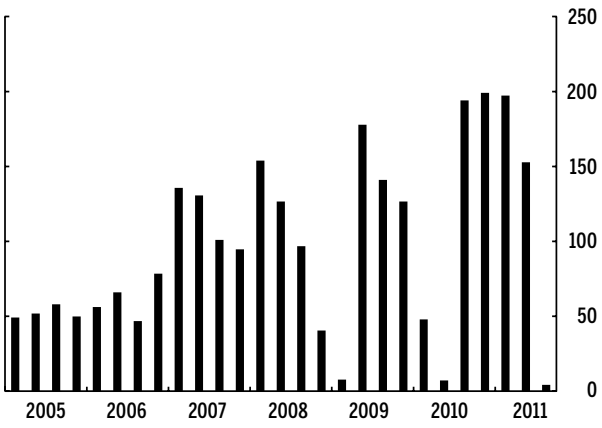

Note: Data shown are end-of-quarter figures.

Source: International Monetary Fund, International Financial Statistics. 
Table 19 indicates that, based on the TIC data, China holds about 12 percent of outstanding Treasury bills, notes, and bonds, up from 2 percent a decade ago. The total value of China's reported holdings of Treasuries and agency bonds at the end of 2010 was $\$ 1.3$ trillion, which is almost certainly an underestimate of the actual amount. Panel A of Figure 22 shows that China's vast holdings of U.S. securities are mostly in the form of long-term Treasury bonds and, second to that, agency debt. ${ }^{16}$ China invests a relatively small amount in U.S. equities.

\section{China's Holdings of U.S. Government Debt}

\begin{tabular}{lccccr}
\hline \multirow{2}{*}{ Aspect of Holdings } & \multicolumn{2}{c}{ As of March 30, 2000 } & & \multicolumn{2}{c}{ As of June 30, 2011 } \\
\cline { 2 - 3 } \cline { 5 - 6 } & Treasuries & Agencies & & Treasuries & Agencies \\
\hline Total outstanding held by the public & 3,519 & 3,334 & & 9,742 & 7,185 \\
Total held by foreigners & 884 & 261 & & 4,501 & 1,197 \\
China's holdings & 71 & 20 & & 1,166 & 332 \\
China's share of foreign holdings & $8.0 \%$ & $7.5 \%$ & & $25.9 \%$ & $27.8 \%$ \\
China's share of total outstanding & $2.0 \%$ & $0.6 \%$ & & $12.0 \%$ & $4.6 \%$ \\
Foreign share of total outstanding & $25.1 \%$ & $7.8 \%$ & & $46.2 \%$ & $16.7 \%$ \\
\hline
\end{tabular}

Note: The first three rows are expressed in billions of U.S. dollars. Treasury debt is defined as "debt held by public." Including "Intragovernmental holdings," total Treasury debt was $\$ 5.8$ trillion on March 30,2000 , and was $\$ 14.3$ trillion on June 30, 2011. Total agencies outstanding represents total debt owed by government-sponsored enterprises (GSEs) and by GSE-backed mortgage pools, less agency and GSE-backed securities owned by GSEs. Chinese and total foreign holdings of agencies in June 30, 2011, were estimated from total stock data in June 30, 2010, and net purchases of long-term agency debt in all subsequent months over the next year. The U.S. Treasury International Capital System contains data on holdings by Chinese official and nonofficial institutions, and not just by the Chinese government. Some of the Treasury and Agency holdings reported in this table may not be held by the State Administration of Foreign Exchange.

Sources: U.S. Treasury International Capital System; Federal Reserve Flow of Funds; Treasury's Bureau of Public Debt; authors' calculations.

\section{FIGURE 22}

\section{Foreign Portfolio Holdings of U.S. Portfolio Securities}

\section{A China}

B Cross Country, June 2010

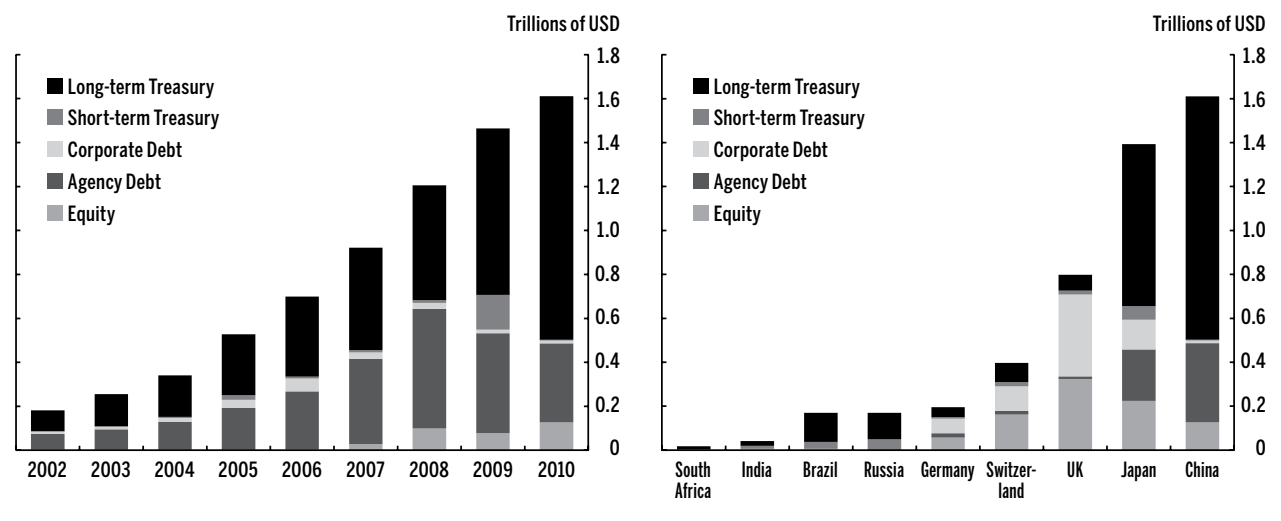

Source: U.S. Department of the Treasury. 
From a cross-country perspective, as of June 2010 China's total holdings of U.S. securities ranked as the highest in absolute volume (Figure 22, panel B), notwithstanding the likely underestimation. One striking feature is that China holds only a small amount of U.S. equities, compared with the reserve currency economies.

The composition of U.S. portfolio investment in Chinese securities (which excludes foreign direct investment) is quite different. Figure 23 shows that the United States invests only a modest amount of roughly $\$ 100$ billion in Chinese securities. More important, most of this investment goes into Chinese equity markets as opposed to debt. The same pattern holds for U.S. investment in other key emerging markets and advanced economies.

China's capital account liberalization could have significant effects on the volume and, more important, the composition of investments in the United States. The major channel for capital flows to the United States is of course the official accumulation of foreign exchange reserves. This pattern of flows poses a significant risk for China on the asset side of its external balance sheet. High and rising U.S. debt levels are likely to adversely affect productivity growth in the United States. Given the relatively high productivity growth in China, even a slowdown in its growth could leave a large productivity growth gap between the two countries. The resulting appreciation of the renminbi against the dollar, whenever it happens, will erode the domestic currency value of China's stock of U.S. Treasuries.

Why is China continuing to accumulate so many reserves? In addition to the precautionary motive for holding reserves, a more straightforward explanation

\section{FIGURE 23}

\section{U.S. Portfolio Holdings of Foreign Securities}

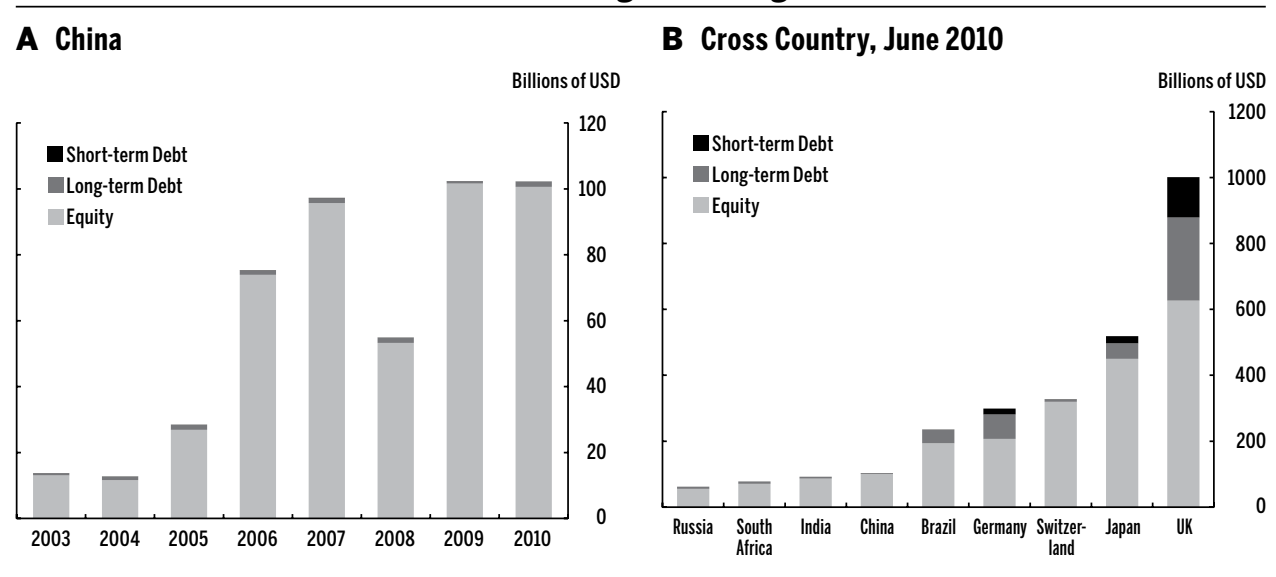


of China's reserve accumulation is that it results from a mercantilist policy of keeping the currency undervalued to gain a competitive advantage for the country's exports. China has in fact tried to offset some of this pressure on its currency by liberalizing outflows, as discussed earlier. But the lack of financial market development makes it difficult for households to diversify their portfolios internationally. Moreover, it contributes to the high and rising household saving rate in China (Chamon, Liu, and Prasad 2010; Lardy 2011). A more flexible exchange rate and a broader financial system that facilitates hedging against currency risk would reduce reserve accumulation, while simultaneously reducing the "fear of floating." A deeper and broader financial system would also reduce the risks from the greater capital flow volatility to which China will be exposed as the capital account becomes more open. For instance, a richer set of derivatives markets would enable private agents, including corporations, to insure against a variety of risks associated with capital flows, mitigating the need for reserves as a public insurance mechanism.

Shifting away from policies that intensify reserve accumulation would also allow China to change the structure of its foreign investments. In particular, capital outflows would reduce the pressure on the currency. In the absence of well-developed financial markets that facilitate foreign investments by households, this is to some extent being done by the government. China's sovereign wealth fund, the China Investment Corporation (CIC), and other large institutional investors are already moving aggressively into investments that offer higher yields than U.S. Treasuries or government bonds of other reserve currency economies. Table 20 shows that CIC is shifting away from government bonds into higher-yielding assets. The share of equity holdings in its portfolio rose from 36 percent in 2009 to 48 percent in 2010. Among its diversified fixedincome securities, roughly a third were invested in corporate bonds in 2010, compared with 13 percent in 2009.

As Chinese financial markets become more developed and private investors increase the international diversification of their portfolios, these shifts in China's outward investment patterns are likely to become more pronounced. Thus, the various policy reforms that are needed to support the international role of the renminbi could also create significant changes in China's economy and the patterns of its capital inflows and outflows.

\subsection{Will the Renminbi Knock the Dollar Off Its Pedestal?}

The U.S. dollar remains by far the dominant global reserve currency. Its status was threatened by the rising prominence of the euro, with that currency's share of global foreign exchange reserves rising by nearly 7 percentage points, 
from 18 to 25 percent, during the period 1999-2003 (Figure 24). Much of the increase in the euro's share was matched by a decline in the dollar's share. Since then, however, the shares of the euro and dollar have stabilized, with the dollar's share standing at 63 percent in 2010. However, these figures need to be interpreted with caution, because a rising share of global reserves cannot be allocated across the reserve currencies (Figure 25). This is because certain

\begin{tabular}{|c|c|c|}
\hline \multicolumn{3}{|c|}{$\begin{array}{c}\text { TABLE } 20 \\
\text { CIC's Global Portfolio Distribution } \\
\text { (percent) }\end{array}$} \\
\hline Aspect of Distribution & 2009 & 2010 \\
\hline \multicolumn{3}{|l|}{ Total holdings } \\
\hline Cash funds and other & 32 & 4 \\
\hline Equity & 36 & 48 \\
\hline Fixed income securities & 26 & 27 \\
\hline Alternative investments & 6 & 21 \\
\hline \multicolumn{3}{|c|}{ Diversified fixed-income securities } \\
\hline Government agency bonds & 27 & 9 \\
\hline Government bonds & 44 & 38 \\
\hline Asset-backed securities & 8 & 12 \\
\hline Corporate bonds & 13 & 32 \\
\hline Other structured products & 8 & 9 \\
\hline \multicolumn{3}{|c|}{$\begin{array}{l}\text { Note: CIC reported total "owner's equity" of } \$ 374 \text { billion at the end of } 2010 \text {, with } \\
\text { the global portfolio (including cash) amounting to } \$ 135 \text { billion (CIC Annua } \\
\text { Report } 2010, \text { p. 9). }\end{array}$} \\
\hline $\begin{array}{l}\text { Sources: Figures } 2 \text { and } 3 \text { of China } \\
\text { Figure } 5 \text { of China Investment Cor }\end{array}$ & ikep & •t, 2010; \\
\hline
\end{tabular}

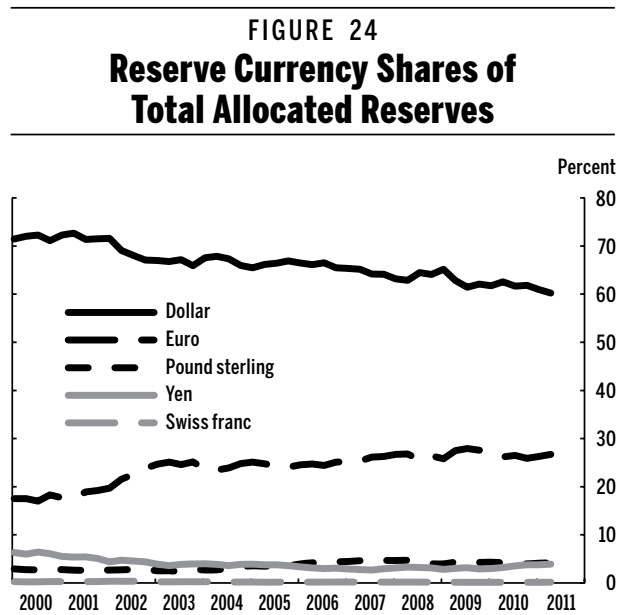

Note: Data from the third quarter of 2010 to the second quarter of 2011 are preliminary.

Source: Quarterly data from International Monetary Fund, Currency Composition of Foreign Exchange Reserves.

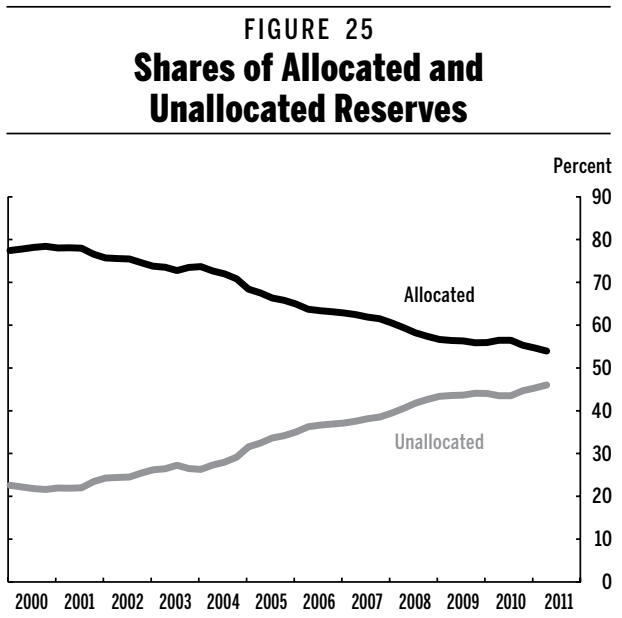

Note: Data from the third quarter of 2010 to the second quarter of 2011 are preliminary.

Source: Quarterly data from International Monetary Fund Currency Composition of Foreign Exchange Reserves. 
countries do not report the currency composition of their reserve holdings to the IMF. Two prominent cases are China and India, which together account for about $\$ 3.5$ trillion of global foreign exchange reserves. Given the sheer size of their reserve holdings, however, it is highly probable that the currency composition of these two countries' reserves is largely concentrated in dollars and that the broader composition is similar to that of global allocated reserves. Other indicators, such as the dollar's share of cross-border foreign currency liabilities of non-U.S. banks, confirm the currency's dominance in global finance (Figure 26).

Despite its status as the dominant existing reserve currency, there are major concerns about the future of the U.S. dollar, related to the uncertain prospects for U.S. macroeconomic stability. Although the Federal Reserve clearly has strong worldwide credibility for its inflation-fighting credentials, rising public debt poses a more serious concern. Figure 27 shows that U.S. gross general government debt is about 90 percent of GDP, and IMF forecasts indicate that it could reach 110 percent of GDP, or nearly $\$ 21$ trillion, by 2016 . This is dangerous and unprecedented terrain for the world's largest economy. The paradox is that, given the weaknesses in Japan and the euro zone, along with emerging markets' demand for safe assets as they accumulate even more reserves, this rising debt may cement the dollar's dominant status in the global financial system.

Figure 27 also shows the gulf that still exists between China and the United States in the availability of safe and liquid assets such as government bonds. The

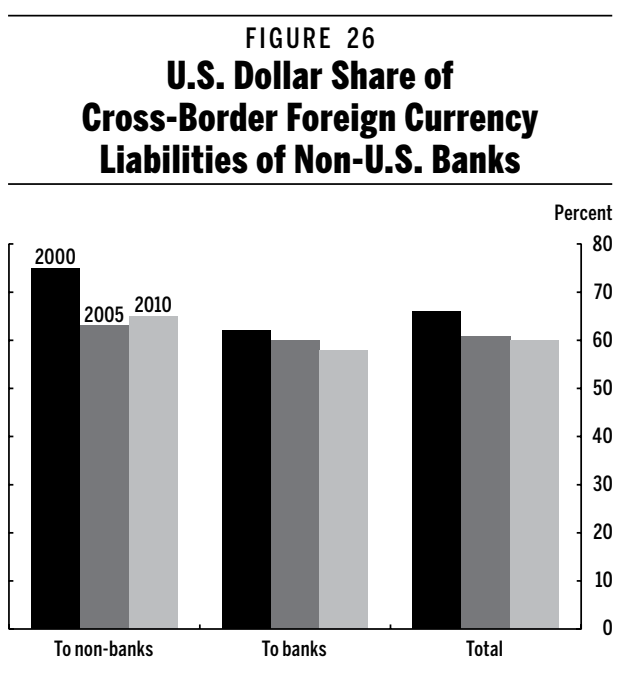

Source: Bank for International Settlements. 


\section{Gross and Net General Government Debt}

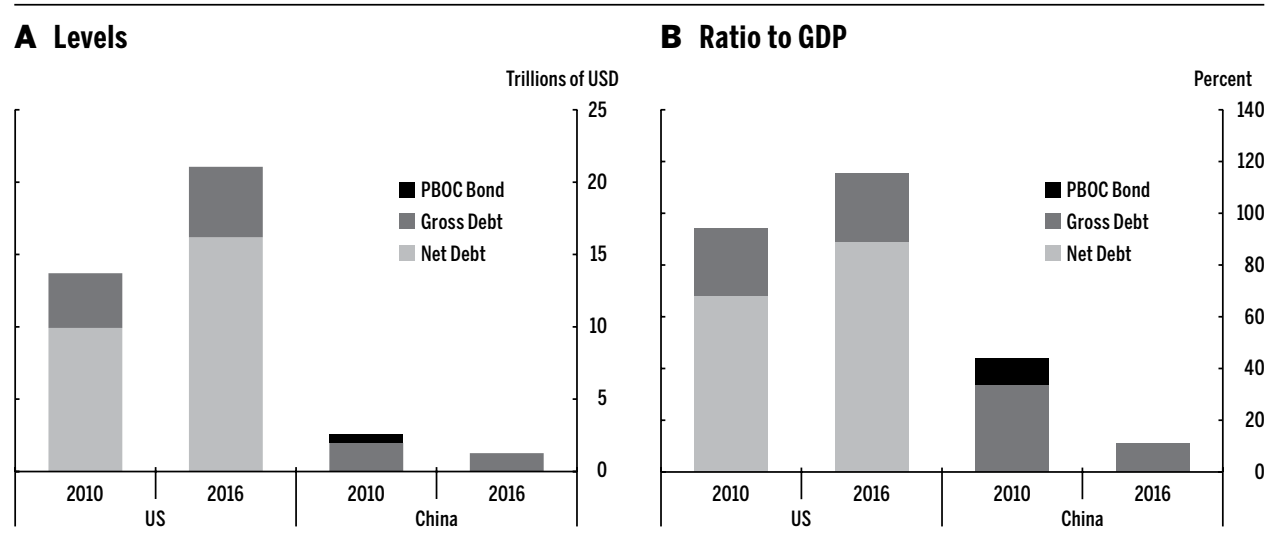

Source: International Monetary Fund, World Economic Outlook; CEIC; authors' calculations.

Notes: Data on net debt for China were not available, and hence only gross debt is shown. Total 2010 debt data for China include revised International Monetary Fund estimates of local government debt.

breadth, depth, and liquidity of U.S. financial markets suggest that its currency will serve as a potent buffer against threats to its dominant status. Rather than catching up to the United States by building up debt, the challenge for China is to develop its other financial markets and increase the availability of high-quality renminbi-denominated assets.

\subsection{The Renminbi and Special Drawing Rights}

The IMF's special drawing rights (SDRs) constitute an international reserve asset created by the IMF. Its value is based on a basket of four reserve currencies-the U.S. dollar, the euro, the Japanese yen, and the British pound sterling. SDRs are distributed among IMF members on the basis of their quotas at their institution. The stock of SDRs now stands at roughly $\$ 320$ billion. ${ }^{17}$ SDRs can in principle be exchanged for freely usable currencies but cannot be used directly in private transactions. This means that increasing the stock of SDRs does not increase the total liquidity of the global monetary system unless a substitution account is used. But such substitution accounts that would result in the net creation of global liquidity via SDR issuance may not be practical, in part because SDRs are not backed by a global central bank and have no support from a fiscal authority (Obstfeld 2011b).

There was considerable discussion in 2011 about a proposal to include the renminbi in the basket of currencies that constitute the SDR. The French government, during its presidency of the Group of Twenty in 2011, promoted this proposal at different venues, viewing it as an important component of the reform 
of the international monetary system. At a G-20 conference in Nanjing, China, in March 2011, French president Nicolas Sarkozy put the issue squarely on the table: "Isn't it the time today to reach agreement on the timetable for enlarging the basket of SDRs to include new emerging currencies, such as the yuan? Who could deny the major role the yuan plays in the international monetary system? Tribute is thus paid to the economic power and the political power of China, a major monetary power."

The communiqué issued at the conclusion of the November 2011 G-20 Summit in Cannes contained this language:

We agreed that the SDR basket composition should continue to reflect the role of currencies in the global trading and financial system and be adjusted over time to reflect currencies' changing role and characteristics. The SDR composition assessment should be based on existing criteria, and we ask the IMF to further clarify them. A broader SDR basket will be an important determinant of its attractiveness, and in turn influence its role as a global reserve asset. This will serve as a reference for appropriate reforms. We look forward to reviewing the composition of the SDR basket in 2015, and earlier if warranted, as currencies meet the criteria, and call for further analytical work of the IMF in this regard, including on potential evolution. (G-20 2011)

During his final press conference at the conclusion of that summit, Sarkozy was more explicit: "The yuan is a clear candidate [for inclusion in the SDR basket], given China's commitment—which I noted with satisfaction-to gradual convertibility."

China itself has been more circumspect about the prospects of expanding the SDR basket. The deputy governor of the PBOC (and also head of the State Administration of Foreign Exchange), Yi Gang, urged the IMF to conduct more research into a shadow SDR and argued that "the IMF should consider including currencies of the BRICS [Brazil, Russia, India, China and South Africa-the world's largest fast-growing emerging economies] countries and other emerging economies when it next reviews its special drawing right (SDR) system by 2015." But Yi was also quoted as saying that "China is in no hurry as the SDR has so far been only a symbolic currency basket."18

SDRs currently account for about 5 percent of world official reserve asset holdings, so the direct effect of including the renminbi in the SDR basket would not be substantial. But the symbolic effect would be substantial, as even the prospect of the renminbi becoming a part of the SDR basket would encourage central banks around the world to begin adding renminbi assets to their 
reserve portfolios. Technically, the renminbi cannot become a part of the SDR basket because it is not a convertible currency. However, the notion that a freely usable currency ought to qualify for the SDR basket has been thrust into the debate, based on the argument that the renminbi already meets the criteria for a freely usable currency, given that it is being increasingly used in trade settlement transactions and in the denomination of deposit accounts offshore.

The IMF's position in 2010 was clear and was summarized as follows in a report on its Executive Board's discussion of the matter: "Directors noted that although China has become the third-largest exporter of goods and services on a five-year average basis and has taken steps to facilitate international use of its currency, the Chinese renminbi does not currently meet the criteria to be a freely usable currency and it would therefore not be included in the SDR basket at this time. Directors urged that this issue be kept under review in light of developments." 19 Thus, it appeared that the IMF intends to apply the convertibility criterion strictly, which would be logical because any currency that is part of the SDR basket would presumably automatically be counted as an official reserve currency.

Technically, the SDR basket consists of the four currencies that are (1) issued by IMF members (or monetary unions that include IMF members) that are the largest exporters, and (2) have been determined by the IMF to be "freely usable." The latter condition was added as a formal criterion only in 2000 and is clearly open to interpretation, as is the number of countries whose currencies are in the SDR basket. The IMF's operational definition of a freely usable currency requires that it be (1) widely used to make payments for international transactions, and (2) widely traded in the principal exchange markets. Thus, the criterion of convertibility is not strictly essential for a currency's inclusion in the SDR basket. By contrast, the IMF's own balance of payments definition of a freely usable currency is one that is liquid, convertible, and used for the settlement of international transactions. The composition of the SDR basket is governed by operational rather than technical criteria, so the lack of convertibility is not a hindrance to including the renminbi (or other emerging market currencies) in the basket.

In November 2011, the IMF proposed the following indicators for evaluating a currency's potential for inclusion in the SDR basket:20

- volume of transactions in foreign exchange spot markets

- volume of transactions in foreign exchange derivatives markets and overthe-counter derivatives

- existence of an appropriate market-based interest rate instrument

- currency composition of official reserve holdings. 
There are no clear benchmarks for any of these criteria, suggesting thatas long as some minimal thresholds are met on each of them-whether or not to include a currency in the SDR basket is ultimately a political decision. China probably already meets the first criterion and is making progress on the second one. Interest rate liberalization would be necessary to meet the third one. The IMF has left itself considerable room to maneuver in response to shifting political winds. For instance, when considering the currency composition of reserves, the IMF coyly suggests that an ancillary indicator could be the number of countries holding a currency in their international reserve portfolios. This would certainly suit China well-as indicated in Appendix D, a number of countries have begun to publicly discuss the possibility and desirability of holding renminbi assets in their reserve portfolios, even if the actual (or proposed) amounts are small as of now.

\section{Conclusion}

Given its size and economic clout, China is adopting a unique approach to the renminbi's role in the global monetary system, which we call "capital account liberalization with Chinese characteristics." As with virtually all other major reforms, China is striking out on its own path to a more open capital account. This is likely to involve removing explicit controls even while attempting to exercise soft control over inflows and outflows through administrative and other measures. The medium-term objective, which we believe will be achieved in the next five years, is an open capital account but with numerous administrative controls and regulations still in place. This will allow the renminbi to play an increasingly significant role in global trade and finance, but in a manner that allows the government to retain some control over capital flows.

Indeed, the renminbi is beginning to play a role in international trade transactions and also starting to appear in the reserve portfolios of certain emerging market central banks. The bilateral currency pact to which China and Japan agreed in December 2011 is an interesting example of how China is attempting to reduce its dependence on the dollar while other countries, especially in the Asian region, appear eager to participate in such agreements because they see advantages to tighter trade and financial links with China. These shifts, which are more symbolic than substantive at present, will develop critical mass over time and have the potential to start transforming the global monetary system.

The Chinese government's recent policy actions are indicative of its serious intent to broaden the global role of its currency. The potential for the renminbi to develop quickly into an international currency is not without historical precedent. The U.S. dollar rose from being a currency with a limited international 
role to being a serious competitor to the pound sterling in just over a decade (Eichengreen and Flandreau 2010). The big challenge for the Chinese government is to back up its modest international policy actions with substantial domestic reforms. To promote its broader international ambitions without waiting for its domestic policy reforms to catch up, China will need to continue promoting the international use of the renminbi using Hong Kong as a platform. Over the medium term, as the capital account becomes more open and financial markets become more developed, this strategy will shift more toward the promotion of Shanghai as an international financial center.

Although China's rapidly growing size and dynamism are enormous advantages that will help promote the international use of its currency, its low level of financial market development is a major constraint on the likelihood of the renminbi attaining reserve currency status. Moreover, in the absence of an open capital account and free convertibility of the currency, it is unlikely that the renminbi will become a prominent reserve currency, let alone challenge the dollar's dominance. On the basis of the anticipated pace of reforms, we believe that the renminbi will become a competitive reserve currency within the next decade, eroding but not displacing the dollar's dominance.

Even with only gradual financial market development, we foresee that the renminbi will be included in the basket of currencies that constitute the IMF's special drawing rights basket within the next five years. The IMF needs China a lot more than China needs the IMF, and the prospect of the renminbi's inclusion in the SDR basket could be seen as a way for the IMF-and the international community that it represents-to exercise leverage over China in internalizing the global repercussions of its domestic policies.

The Chinese government's approach to policies that promote the renminbi's use as an international currency is inherently linked to domestic macroeconomic objectives and financial market development. The impact of the renminbi on the global monetary system and whether it contributes to greater global financial stability depends on the manner and speed with which China opens up its capital account and develops its financial markets, what other policy changes are put in place to support this process, and what the implications are for China's own growth and stability.

The big question now is whether China's government will use the goal of making the renminbi a global currency to catalyze momentum on a broad agenda of domestic policy reforms that are required to support this goal. Ultimately, the path of China's growth and its role in the global economy will depend on those policy choices. 


\section{APPENDIX A}

\section{Changes to Capital Controls in China, 2004-10}

This appendix extends the documentation of changes to capital controls in Prasad and Wei (2007) to January 31, 2011. Reference source: IMF's Annual Reports on Exchange Arrangements and Exchange Restrictions (AREAER, 2004-11). All items are quotations from original source.

\section{Changes during 2004}

January 1. Under the Closer Economic Partnership Arrangement, (1) the asset requirement for Hong Kong Special Administrative Region (SAR)-incorporated banks to open branches in mainland China was reduced to $\$ 6$ billion from $\$ 20$ billion; (2) the requirement that a representative office be set up in mainland China before a Hong Kong SAR bank established a joint venture bank or joint venture finance company in mainland China was lifted; and (3) for mainland China branches of Hong Kong banks to apply to conduct renminbi business, the minimum number of years of business operations on the mainland required of the banks was reduced to two years from three years.

June 27. Foreign-funded domestic banks were not permitted to convert proceeds from debt contracted abroad into renminbi and were not allowed to purchase foreign exchange for servicing such debts.

June 27. Capital remitted as inward foreign direct investment can be converted into renminbi only on the basis of a written payment order by the foreign-invested enterprise.

December 1. Foreign heirs, including those from Hong Kong and Macao, were permitted to take inheritances out of the country. Emigrants were allowed to take legally obtained personal assets up to the equivalent of $\$ 200,000$; for larger amounts, staggered transfers were required to be made over a minimum period of two years.

\section{Changes during 2005}

January 15. The reserve requirements on accounts denominated in domestic and foreign currencies were unified at 3 percent.

\section{Changes during 2006}

April 13. Domestic banks' overseas foreign exchange fund management services for customers was expanded; qualified banks are allowed to combine renminbi funds of domestic institutions and individuals and purchase foreign exchange within limits to invest in fixed-income products abroad; qualified fund management firms and other securities firms are allowed to combine within limits foreign exchange funds of domestic institutions and individuals for overseas portfolio investments, including for stocks; insurance institutions' securities investment business abroad was expanded; qualified insurance companies are allowed to purchase foreign currency to invest in fixed-income products and currency market instruments abroad, with the foreign exchange purchase amount subject to a certain proportion of the insurance institution's total assets.

July 1. The limit on the amount of foreign exchange used in Chinese enterprises' direct investments abroad was abolished.

September 1. Nonresidents may purchase domestic real estate based on actual needs and for their own use.

\section{Changes during 2007}

February 1. The limit on foreign exchange purchases by residents for remittance abroad for personal reasons was increased to $\$ 50,000$ a year. Resident individuals' foreign exchange receipts up to $\$ 50,000$ may be processed with a bank on proof of identity. 
March 2. The State Administration of Foreign Exchange (SAFE) reduced the 2007 short-term external debt quotas of Chinese-funded banks to 30 percent and those of nonbank financial institutions and foreign-funded banks to 60 percent of their 2006 equivalents. In addition, Chinese-funded banks were required to reduce their outstanding short-term external debts to 30 percent or less and nonbank financial institutions and foreign-funded banks to 60 percent or less of their 2006 quotas by March 31, 2008.

August 30. The SAFE fully decentralized the task of verification of sources of foreign exchange capital for outward investment. SAFE branches were authorized to verify sources of foreign exchange capital for outward investment projects of $\$ 10$ million or more.

December 9. The overall Qualified Foreign Institutional Investors (QFII) quota was raised to $\$ 30$ billion from $\$ 10$ billion.

\section{Changes during 2008}

March 7. Regulated financial institutions that meet risk management requirements were allowed to trade in gold futures on the domestic market.

July 14. The registration management system for the provision of trade credit between residents and nonresidents was implemented for advance receipts of export payments.

August 29. The amount of capital remitted as inward foreign direct investment that may be converted to renminbi only with a written payment order by the company making the foreign investment was reduced to $\$ 50,000$ from $\$ 200,000$.

October 1. The registration management system for the provision of trade credit between residents and nonresidents was implemented for deferred payments of imports.

November 15. The registration management system for the provision of trade credit between residents and nonresidents was implemented for advance receipts of import payments.

December 1. The registration management system for the provision of trade credit between residents and nonresidents was implemented for deferred payments of exports.

\section{Changes during 2009}

August 1. The protocol for review of the source of foreign exchange funds for outward direct investment changed from ex ante examination to ex post registration, and the review and approval requirement for outward remittances of funds for outward direct investments was canceled. During the preparatory stage before the formal startup of the foreign project, with SAFE approval, domestic institutions may remit a certain percentage of the total investment abroad.

September 29. With respect to Qualified Domestic Institutional Investors, the net amount of funds remitted abroad by securities dealers for investment in securities abroad must not exceed approved investment limits.

September 29. The upper limit on individual QFII investments was raised from $\$ 800$ million to $\$ 1$ billion, and the principal lock-up period for medium- and long-term investments by pension funds, insurance funds, and open-end funds was decreased to three months from 6 to 12 months; the principal lock-up period for other institutions was decreased from three years to one year.

\section{Changes during 2010}

August 17. Foreign central banks, monetary authorities, Hong Kong SAR and Macao SAR RMB clearing banks, and foreign banks engaged in RMB trade clearing were allowed to invest in the China interbank bond market. These investments have several limitations, but there is no minimum holding period. 


\section{Recent Developments Pertaining to the International Use of the Renminbi}

This appendix documents recent developments related to the greater international use of the renminbi and other relevant financial market developments. A variety of official and unofficial sources were used in compiling this appendix. "AREAER" refers to the IMF's Annual Reports on Exchange Arrangements and Exchange Restrictions; "HKMA" is the Hong Kong Monetary Authority; and "PBOC" stands for the People's Bank of China.

\section{Changes during 2004}

January 18. Mainland residents are allowed to use renminbi-denominated bankcards for tourismrelated payments in the Hong Kong Special Administrative Region (SAR). (AREAER 2004, 229, "Arrangement for payments and receipts" change.)

January. Personal renminbi businesses are launched. (HKMA)

February 25. Participating banks in the Hong Kong SAR can establish renminbi-denominated accounts, accept renminbi deposits, provide RMB-Hong Kong dollar exchange services, and effect renminbi remittances for residents and specified commercial customers in Hong Kong. (AREAER 2004, 229, "Arrangement for payments and receipts" change.)

February 25. The number of primary dealers for open market operations is raised by the PBOC after some securities companies, insurance companies and rural credit cooperative unions were approved as primary dealers. (PBOC)

April 1. The amount for which documentary evidence is required in order to surrender foreign exchange is raised to the equivalent of $\$ 50,000$ from $\$ 20,000$. (AREAER 2004, 229, "Proceeds from invisible transactions and current transfers" change.)

May 1. The amount of previous current account foreign exchange income that qualifying enterprises are allowed to retain is increased to the equivalent of 30 percent or 50 percent from 20 percent. (AREAER 2004, 229, "Exports and export proceeds" change)

May 1. The definition of qualifying enterprises is adjusted to include enterprises with specifically allowed foreign exchange business. Previously, the list included enterprises with specific foreign exchange volume or capital amounts. (AREAER 2004, 229, "Exports and export proceeds" change.)

August 12. The PBOC puts forth clearing and reflow mechanisms for banking in renminbi in the Macao SAR. (PBOC)

September 8. Mainland China residents are allowed to use renminbi-denominated bank cards for tourism-related payments in the Macao SAR. (AREAER 2005, 235, "Arrangement for payments and receipts" change.)

November 1. The PBOC allows qualified securities firms to issue short-term financing bills to qualified institutional investors in the interbank market. (PBOC)

November 3. Participating banks in the Macao SAR are allowed to open renminbi-denominated accounts; accept renminbi deposits; provide exchange services between renminbi, the Hong Kong dollar, and the Macao pataca; and effect renminbi remittances for residents and designated commercial customers in the Macao SAR. (AREAER 2005, 235, "Arrangement for payments and receipts" change.)

November 17. The China Development Bank is approved for the issuance of bonds with floating interest rates around the seven-day repo benchmark rate on the interbank market. (PBOC)

December 28. For the first time, the PBOC issues forward central bank bills. (PBOC) 


\section{Changes during 2005}

January 1. The limit on the amount of renminbi that a domestic or foreign resident can bring in and out of China per time is increased to 20,000 yuan from 6,000 yuan. (PBOC)

January 1. Persons paying for their own studies abroad are allowed to purchase foreign exchange up to $\$ 20,000$ in addition to tuition and fees. The amount had been $\$ 20,000$, including tuition and fees. (AREAER 2006, 300, "Payments for invisible transactions and current transfers" change.)

January 10. Residents of mainland China may use certain renminbi-denominated bank cards for purchases in Thailand and for withdrawing cash and making purchases in Korea and Singapore. (AREAER 2006, 300, "Arrangements for payments and receipts" change.)

January 15. The reserve requirements on accounts denominated in domestic and foreign currency are unified at 3 percent. (AREAER 2006, 300, "Provisions specific to commercial banks and other credit institutions" change.)

February 18. The PBOC and other government ministries announce that international development organizations that are eligible can issue renminbi-denominated bonds. (PBOC)

April 6. A pilot program intended to allow commercial banks' setup of fund management firms is announced. (PBOC)

April 30. The PBOC approves the Pan-Asian Index Fund's access to the interbank bond market in China, making it the first institutional investor outside China to do so. (PBOC)

May 18. The interbank foreign exchange market formally puts forth foreign currency trading. The China Foreign Exchange Trading System offers trading of eight currency pairs. (PBOC)

June 15. The PBOC puts forth forward bond transactions on the interbank bond market. (PBOC)

June 17. Notice that would allow insurance companies to invest in overseas stock markets is issued. (PBOC)

August 2. The number of banks allowed to conduct forward transactions and interbank forward transactions is expanded, and the restrictions on maturity are lifted. (AREAER 2006, 299, "Exchange arrangement" change.)

August 2. Domestic institutions that are allowed to conduct current account transactions can retain foreign exchange equivalent to 50 percent (previously, 30 percent) or 80 percent (previously, 50 percent) of their foreign exchange earnings from current transactions in the previous year; domestic institutions or enterprises that had no current foreign exchange income in the previous year could retain up to the equivalent of $\$ 200,000$ (previously, $\$ 100,000$ ). (AREAER 2006, 300, "Exports and export proceeds" change.)

August 2. The PBOC starts renminbi swaps on the foreign exchange market. (PBOC)

August 3. Limits on foreign exchange purchases for private travel are increased: (1) If travel is for six months or less, the limit is increased to the equivalent of $\$ 5,000$ from $\$ 3,000$; (2) if travel is for a period exceeding six months, the limit is increased to $\$ 8,000$ from $\$ 5,000$. (AREAER 2006, 300, "Payments for invisible transactions and current transfers" change.)

August 9. The PBOC starts a credit asset and mortgage loan securitization pilot program, for which the China Construction Bank and China Development Bank are chosen as pilot institutions. (PBOC)

August 15. Interbank foreign exchange forward trading products are introduced by the China Foreign Exchange Trading System. The Industrial and Commercial Bank of China and China Construction Bank complete two forward deals of the U.S. dollar against the renminbi on the same day.

August 16. The State Administration of Foreign Exchange (SAFE) issues a notice that allows annual balance control to replace the case-by-case approval used when domestic banks designated for foreign exchange make guarantees for Chinese companies engaged in investment overseas. This system now 
applies to all banks designated as qualified for domestic foreign exchange, and all qualified domestic institutions' foreign investment enterprises can now accept domestic guarantees. (PBOC)

August 30. The State Council approves a policy that allows commercial banks to invest in asset-backed securities. (PBOC)

September 22. The SAFE issues notice to extend the coverage of foreign exchange trading positions. (PBOC)

October 9. The Asian Development Bank and the International Finance Corporation are approved for the issuance of renminbi-denominated bonds valued at 1 billion yuan and 1.13 billion yuan, respectively, on the interbank bond market, marking the first time that foreign institutional investors participate in the Chinese bond market. (PBOC)

November 1. The PBOC expands its position squaring and clearing services to Hong Kong banks conducting renminbi business in order to meet renminbi business development needs. Furthermore, the PBOC also expands renminbi business for Hong Kong residents and raises cash exchange limits.

December 5. Renminbi-denominated cards may be used in France, Germany, Indonesia, Luxembourg, the Philippines, Spain, the United States and Vietnam. (AREAER 2006, 300, "Arrangements for payments and receipts" change.)

December 8. The PBOC approves China Construction Bank and China Development Bank's pilot issuance of asset-backed securities on the interbank market. (PBOC)

December 13. The PBOC issues a circular to streamline administrative procedures, expand the investor base and increase market transparency in the corporate bond market. (PBOC)

December 15. Renminbi-denominated cards may be used in Belgium and Japan. (AREAER 2006, 300, "Arrangements for payments and receipts" change.)

December 18. The number of banks permitted to be market makers is increased from 13 to 21 . (AREAER, 272, "Exchange arrangement" change.)

December 28. Thirteen banks are introduced to be market makers in foreign exchange. (AREAER 2006, 300, "Exchange arrangement" change.)

\section{Changes during 2006}

January 4. Over-the-counter transactions and market makers are put forth on the interbank foreign exchange market. (PBOC)

January 24. The PBOC announces pilot renminbi interest rate swaps on the interbank market. (PBOC)

March 10. The China Foreign Exchange Trading System and the Chicago Mercantile Exchange (CME) sign an agreement that provides China's financial sector with access to the electronic trading of CME's interest rate and foreign exchange products. (PBOC)

April 15. On approval, qualified fund management firms and other securities management companies now may, within a certain limit, combine foreign exchange funds owned by domestic institutions and individuals and use the funds overseas for portfolio investments, including for stocks. (AREAER 2007, 273, "Provisions specific to institutional investors" change.)

April 18. The PBOC allows commercial banks to invest in financial products abroad on behalf of domestic clients. (PBOC)

May 1. Residents are now allowed to purchase foreign exchange up to $\$ 20,000$ a year for current account transactions. (AREAER 2007, 272, "Payment for invisible transactions and current transfers" change.)

July. The PBOC issues a circular that puts forth brokerage business on the interbank bond and lending markets. (PBOC) 
September 1. The Interim Implementing Regulations on Qualified Foreign Institutional Investors (QFII) Securities Investments in China is abolished, and the administration of QFII Securities Investments in China starts. (AREAER 2007, 273, "Provisions specific to institutions investors" change.)

October 20. Any foreign exchange transaction that is eligible for spot settlement under the regulations becomes eligible for forward settlement. (AREAER 2007, 272, "Exchange arrangement" change.)

December 11. China provides full national treatment for foreign banks. Under its World Trade Organization agreement, foreign banks, after being incorporated locally, are permitted to engage in the same range of financial services as Chinese banks, including taking retail renminbi deposits, and they are regulated and supervised in the same way as domestic banks. Foreign bank branches that have the China Banking and Regulatory Commission's approval to conduct renminbi business may accept fixed-term deposits from Chinese citizens living in China in the amount of no less than 1 million renminbi per transaction. (AREAER 2007, 272, "Provision specific to commercial banks and other credit institutions" change.)

December 29. The China Foreign Exchange Trading System founds its own clearinghouse in order to better control clearing risks and improve market liquidity. (PBOC)

\section{Changes during 2007}

January 4. The Shanghai Interbank Offered Rate (SHIBOR) is officially launched. (PBOC)

January 14. The PBOC allows domestic financial institutions to issue renminbi financial bonds in Hong Kong, subject to approval.

January 15. The number of market-maker banks is increased from 21 to 22. (AREAER 2007, 273, "Exchange arrangement" change.)

February 1. The limit on foreign exchange purchases by residents for current transactions is increased to $\$ 50,000$ a year from $\$ 20,000$. Resident individuals' foreign exchange purchases up to this limit are processed with personal identification; and, after bank declarations, foreign exchange purchases in excess of this limit may be processed after bank verification of actual-need documents stipulated by the SAFE. (AREAER 2008, 321, "Payment for invisible transactions and current transfers" change.)

March 20. A notice that allows corporate annuity funds access to the interbank bond market is issued.

April 9. The China Foreign Exchange Trading System puts forth a new trading platform that synthesizes renminbi spot, forward, and options transactions against other currencies plus pair transactions among foreign currencies. (PBOC)

June 7. The Shanghai Gold Exchange obtains the PBOC's approval to admit operational units of foreign banks as its members. (PBOC)

June 26. Renminbi bond issuance starts in Hong Kong. (PBOC)

July 5. The Qualified Domestic Institutional Investor (QDII) program starts.

August 12. Domestic institutions are now allowed to retain foreign exchange receipts from current account transactions in their foreign exchange current accounts according to their operational needs. The previous limits on the retention of foreign exchange receipts are eliminated. (AREAER 2008, 321, "Exports and export proceeds" change.)

August 17. Renminbi swaps against the U.S. dollar, euro, yen, Hong Kong dollar, and pound sterling are introduced in the interbank foreign exchange market. (PBOC)

August 20. The SAFE puts forth a pilot program that allows domestic residents to invest in securities overseas under controllable risks. (PBOC)

September 3. The National Association of Financial Market Institutional Investors-which includes members of the interbank market, foreign exchange market, and gold market—is formed. (PBOC)

September 29. The PBOC introduces forward rate agreements. (PBOC) 


\section{Changes during 2008}

January 18. The PBOC fully puts forth interest rate swaps. (PBOC)

July 25. The China Domestic Foreign Currency Payment System is started.

August 5. The foreign exchange income of domestic institutions and individuals is now allowed to be deposited abroad, under the terms and conditions specified by the Foreign Exchange Administration Department; however, these regulations have not yet been issued. (AREAER 2009, 539, "Exports and export proceeds" change.)

August 20. The SAFE approves a pilot program to allow for individual domestic and foreign currency exchange business in Beijing and Shanghai, subject to approval. (PBOC)

August. The ceiling on the initial investment amount for each new institutional investor is raised to $\$ 1$ billion from $\$ 800$ million. (Lardy and Douglass 2011, 11)

December. The China Banking and Regulatory Commission now allows commercial banks to provide loans to firms for cross-border mergers-and-acquisitions purposes. (Lardy and Douglass 2011, 10)

\section{Changes during 2009}

January 7. The PBOC eliminates restrictions that previously stipulated that a bond must exceed 500 million yuan in value to be traded on the interbank bond market. (PBOC)

March 16. The PBOC and HKMA start a cross-border multicurrency payment arrangement.

March 17. The SAFE announces the "Notice on the Decision on Short-Term External Debt Quotas for Financial Institutions in 2009," which raises the short-term debt quotas of financial institutions. (PBOC)

March 18. The PBOC now allows fund management companies to open bond accounts on the interbank bond market under the category of a specific asset management portfolio. (PBOC)

April 8. The State Council announces a pilot program that allows exporters and importers in five cities-Shanghai, Guangzhou, Shenzhen, Zhuhai, and Dongguan—to settle cross-border trade deals in renminbi. (PBOC)

May 14 and June 24. The PBOC approves the Bank of East Asia's and the Hong Kong and Shanghai Banking Corporation (China)'s issuance of 4 billion yuan and 3 billion yuan, respectively, in renminbidenominated bonds in Hong Kong. (PBOC)

May. The Ministry of Commerce announced new rules regarding project approval that seek to shorten the time to gain approval, raise value thresholds, and boost discretionary power of the ministry's local branches. (Lardy and Douglass 2011, 10)

July. Renminbi cross-border trade settlement starts in pilot cities. (PBOC)

September 28. The Ministry of Finance of China announces the issuance of the first sovereign renminbi-denominated bond in Hong Kong. (HKMA)

November 28. The Interbank Market Clearing House Co., Ltd., is formally established in Shanghai. (PBOC)

December 14. The PBOC broadens the range of transactions for which it provides renminbi position squaring and clearing for banks in Macao. (PBOC)

\section{Changes during 2010}

March 24. The PBOC and the National Bank of the Republic of Belarus sign a bilateral local currency settlement agreement. This represents the first such agreement for general trade transactions that China has signed with a nonneighboring country. (PBOC) 
June 22. The PBOC, along with other ministries, jointly announces the "Notice on Expansion of the Pilot Renminbi Settlement of Cross-Border Trade Program.” This measure broadens the geographic coverage of the renminbi-settlement pilot program. Cross-border-settlement business is also expanded beyond trade items to other balance of payment items. Current account transactions between 20 provinces and cities on the mainland and the rest of the world may now be settled in renminbi. Previously, transactions had to be settled in convertible currencies. (PBOC)

July 7. Hopewell Highway Infrastructural Ltd announces the issuance of renminbi-denominated bonds in Hong Kong, marking the first corporate dim sum bond issuance.

July 13. The Bank of China (Hong Kong) is authorized to serve as the clearing bank for renminbi banknotes in Taiwan. (PBOC)

July 19. Financial institutions in the Hong Kong SAR_including banks, securities brokerages, and insurance companies-are now allowed to open renminbi accounts. In addition, individuals and corporations can now undertake payments and transfers of renminbi between these banks and interbank settlement in renminbi. To facilitate the use of the renminbi in trade transactions, foreign banks engaged in such settlements were allowed to open renminbi correspondent accounts with Chinese banks as of July 2009 (AREAER 2011, 631, "Nonresident accounts" change.)

August 19. McDonald's announces the issuance of renminbi bonds worth 200 million yuan, marking the first issuance of renminbi bonds by a multinational corporation. (Financial Times)

August. The first offshore renminbi mutual fund is started. (Standard and Chartered Bank)

October 1. Nonresident nonbank institutions accepting payments for exports to China in renminbi are now allowed to deposit the proceeds from such transactions in correspondent accounts with Chinese mainland banks. Limited trade financing is also possible through the correspondent accounts (AREAER 2011, 632, "Nonresident accounts" change.)

October 1. Pilot projects for the depositing of export proceeds abroad are launched in four areas: Beijing, Guangdong (including Shenzhen), Shandong (including Qingdao), and Jiangsu. Eligible domestic enterprises in pilot project areas may apply to local SAFE branches to deposit export proceeds abroad and, on approval, participate in the pilot projects. In accordance with the relevant regulations, the opening and closing of external accounts and funds receipts and payments must be processed and the relevant information reported to the SAFE. (AREAER 2011, 632, "Exports and export proceeds" change.)

October. A currency swap line between HKMA and PBOC is activated after the 8 billion renminbi quota for the Bank of China is exhausted.

November 22. The PBOC authorizes the China Foreign Exchange Trading System to set up direct Russian ruble trading with the renminbi on the interbank foreign exchange market. (PBOC)

November 24. Caterpillar announces the issuance of 1 billion yuan worth of renminbi-denominated bonds. (Financial Times)

November. Issuances of renminbi-denominated sovereign bonds are conducted through the Central Moneymarkets Unit. (HKMA)

December 8. The number of Chinese exporters allowed to participate in renminbi settlement is increased from 365 to 67,359 . (PBOC)

December 15. The Russian Moscow Interbank Currency Exchange starts renminbi-ruble trading. (PBOC)

December. The Bank of China (Hong Kong) Offshore RMB Bond Index, the first Hong Kong renminbi bond index, is launched. 


\section{Changes during 2011}

January 1. The SAFE classifies foreign exchange market makers into three types to increase liquidity in China's foreign exchange market and boost its development: spot trading market makers, forwards and swap trading market makers, and comprehensive market makers. Twenty-six banks have been approved as spot market makers, and 18 have been approved as forward swap market makers. Currently there are no comprehensive market makers. (AREAER 2011, 632, "Exchange arrangement" change.)

January 6. Resident enterprises in 20 provinces and cities on the mainland are now allowed to use renminbi for outward foreign direct investment in countries that accept such settlement. Previously, such payments had to be settled in convertible currencies. Banks in Hong Kong can provide renminbi funds to facilitate these transactions. (AREAER 2011, 632, "Arrangements for payments and receipts" change, HKMA.)

January. The Bank of China is approved to set up renminbi-denominated deposit accounts in New York City.

February 14. The PBOC allows RMB-FOREX options trading on the interbank foreign exchange market. (PBOC)

February. The Qualified Limited Foreign Partner (QLFP) pilot program starts in Shanghai.

June 23. The PBOC signs a new bilateral local currency settlement agreement with the Central Bank of the Russian Federation. (PBOC)

August 23. Cross-border trade settlement in renminbi is extended to the entire nation. (PBOC)

September 14. HSBC announces that it has become the first foreign bank to offer renminbi services and products in Taiwan.

Third quarter. Renminbi-denominated corporate bond issuance exceeds that of euro-denominated sales for the first time (Financial Times, September 29, 2011).

October 14. The PBOC announces rules that permit banks to provide settlement services to overseas entities that have made direct investments denominated in renminbi.

October 16. The Chinese Gold \& Silver Exchange launches the world's first renminbi-denominated gold contract in Hong Kong. (CNBC, October 16)

October 17. The Ministry of Commerce issues an announcement that allows foreign direct investment in renminbi from outbound investors.

November 10. The PBOC signs an agreement with the Austrian Central Bank to allow the latter to invest in the interbank bond market in China. (PBOC)

November. JP Morgan Asset Management is allowed to create a $\$ 1$ billion renminbi-denominated fund under the Qualified Limited Partners Program, making it the largest foreign manager of a renminbidenominated fund so far.

December 16. Renminbi offshore is allowed to be used for purchasing equities in mainland China (Financial Times, December 18, 2011).

December 25. China and Japan agree to promote local currency cross-border transactions, direct foreign exchange, bond market development, and other programs. 
APPENDIX C

\section{Bilateral Local Currency Central Bank Swap Agreements with China since 2008}

\begin{tabular}{llcc}
\hline Bank & Date & Amount (billion yuan) & $\begin{array}{c}\text { U.S. Dollar Equivalent } \\
\text { (billion) }\end{array}$ \\
\hline Bank of Korea & 12 Dec. 2008 & 180 & 26.3 \\
& 26 Oct. 2011 & 360 & 56.5 \\
Hong Kong Monetary Authority & 20 Jan. 2009 & 200 & 29.2 \\
& 22 Nov. 2011 & 400 & 62.9 \\
Bank Negara Malaysia & 8 Feb. 2009 & 80 & 11.7 \\
National Bank of the Republic of Belarus & 11 March 2009 & 20 & 2.9 \\
Bank of Indonesia & 23 March 2009 & 100 & 14.6 \\
Central Bank of Argentina & 2 April 2009 & 70 & 10.2 \\
Central Bank of Iceland & 9 June 2010 & 3.5 & 0.5 \\
Monetary Authority of Singapore & 23 July 2010 & 150 & 22.1 \\
New Zealand Reserve Bank & 18 April 2011 & 25 & 3.8 \\
Central Bank of the Republic of Uzbekistan & 19 April 2011 & 0.7 & 0.11 \\
Central Bank of Mongolia & 19 April 2011 & 5 & 0.8 \\
National Bank of Kazakhstan & 13 June 2011 & 7 & 1.1 \\
Bank of Thailand & 22 Dec. 2011 & 70 & 11.1 \\
State Bank of Pakistan & 23 Dec. 2011 & 10 & 1.6 \\
\hline Note: The bilateral agreement with South Korea was extended to 360 billion yuan on October 26, 2011, from the \\
previous agreement. The bilateral agreement with Hong Kong on November 22, 2011, replaces the previous agree- \\
ment of January 20, 2009. The bilateral agreements listed above cover the years after 2008. A number of bilateral \\
agreements signed before 2008, mostly under the Chang Mai Initiative, are not included. Many of those agreements \\
are not in the local currency. & & \\
Source: People's Bank of China. & & & \\
\hline
\end{tabular}




\section{APPENDIX D}

\section{Additions of Renminbi to Central Bank Reserves across the World}

September 5, 2011. The Central Bank of Nigeria's governor, Limido Sanusi, remarks that one-tenth of the nation's reserves of $\$ 33$ billion would eventually be diversified with the renminbi. He also mentions the next day that the renminbi would replace some current euro holdings. Furthermore, he says that Nigeria is allowed to purchase bonds denominated in renminbi in Hong Kong and Shanghai. (Reuters)

The Central Bank of Nigeria (2011) issues a statement on the same day that it "has finalized arrangements to diversify its external reserves holdings by including the Chinese Renminbi (RMB) to the existing currency mix of United States dollars (USD), the euro (EUR) and the British pound sterling (GBP)."

September 19, 2011. The Financial Times reports that the Central Bank of Malaysia has purchased RMB bonds for its reserve portfolio.

September 2011. The Central Bank of Chile adds yuan to its internal portfolio. It composes 0.3 percent of total internally managed investment portfolio.

December 25, 2011. China and Japan enter a pact to promote direct yuan-yen trades and settlement of transactions directly in each other's currencies. Japan indicates that it will buy Chinese bonds as part of its reserve portfolio (according to the Financial Times, one official was quoted as saying that this was intended as an expression of economic cooperation rather than a serious attempt to further diversify Japan's reserve holdings).

Other central banks that are reportedly considering adding renminbi-denominated reserves:

South Korea (Financial Times, May 4, 2011)

Mongolia (China Daily, September 7, 2011)

South Africa (EconoMonitor RGE, September 22, 2011)

Venezuela (CNN, September 29, 2011). 


\section{REFERENCES}

Angeloni, Ignazio, Agnès Bénassy-Quéré, Benjamin Carton, Zsolt Darvas, Christophe Destais, Jean Pisani-Ferry, André Sapir, and Shahin Vallée. 2011. Global Currencies for Tomorrow: A European Perspective. CEPII Research Report. Paris: CEPII.

Central Bank of Nigeria. 2011. "Nigeria Approves Inclusion of Chinese Renminbi in External Reserves.” Press release, September 5.

Chamon, Marcos, Kai Liu, and Eswar S. Prasad. 2010. Income Uncertainty and Household Savings in China. NBER Working Paper 16565. Cambridge, Mass.: National Bureau of Economic Research.

Chen, Hongyi, Wensheng Peng, and Chang Shu. 2009. "The Potential of the Renminbi as an International Currency.” Manuscript, Hong Kong Monetary Authority.

Chinn, Menzie, and Jeffrey A. Frankel. 2007. "Will the Euro Eventually Surpass the Dollar as Leading International Reserve Currency?" In Gy Current Account Imbalances: Sustainability and Adjustment, ed. Richard Clarida. Chicago: University of Chicago Press.

Chinn, Menzie, and Jeffrey A. Frankel. 2008."Why the Euro Will Rival the Dollar.” International Finance 11(1), pp. 49-73.

Chinn, Menzie, and Hiro Ito. 2008. "A New Measure of Financial Openness.” Journal of Comparative Policy Analysis 10(3), pp. 309-322.

Committee on the Global Financial System. 2007. Financial Stability and Local Currency Bond Markets. Committee on the Global Financial System Paper 28. Basel: Bank for International Settlements.

Dobson, Wendy, and Paul R. Masson. 2009. "Will the Renminbi Become a World Currency?" China Economic Review 20(1), pp. 124-135.

Eichengreen, Barry. 2011a. Exorbitant Privilege: The Rise and Fall of the Dollar and the Future of the International Monetary System. New York: Oxford University Press.

Eichengreen, Barry. 2011b. “The Renminbi as an International Currency.” Manuscript, University of California, Berkeley.

Eichengreen, Barry, and Marc Flandreau. 2010. The Federal Reserve, the Bank of England and the Rise of the Dollar as an International Currency, 1914-39. Bank for International Settlements Working Paper 328.

Errico, Luca, and Alexander Massara. 2011. Assessing Systemic Trade Interconnectedness-An Empirical Approach. International Monetary Fund Working Paper 11/214.

Forbes, Kristin. 2009. "Financial Deepening and Global Currency Usage.” In The Euro at Ten: The Next Global Currency? eds. Jean Pisani-Ferry and Adam Posen. Washington: Peterson Institute of International Economics.

Frankel, Jeffrey. 2005. On the Renminbi: The Choice between Adjustment under a Fixed Exchange Rate and Adjustment under a Flexible Rate. National Bureau of Economic Research Working Paper 11274. 
Frankel, Jeffrey. 2011. "Historical Precedents for the Internationalization of the RMB." Paper prepared for workshop organized by Council on Foreign Relations and China Development Research Foundation, Beijing, November 1.

Goodfriend, Marvin, and Eswar Prasad. 2007. "A Framework for Independent Monetary Policy in China.” CESifo Economic Studies 53(1), pp. 2-41.

Group of 20. 2011. “G-20 Leaders Summit, Final Communiqué.” Cannes, November 3-4.

Hale, Galina. 2007. "Prospects for China's Corporate Bond Market.” Federal Reserve Bank of San Francisco Economic Letter 2007-07, March 16.

Henning, Randall. 2009. The Future of the Chiang Mai Initiative: An Asian Monetary Fund? Policy Brief 09-5. Washington: Peterson Institute for International Economics.

Hong Kong Monetary Authority. 2010. Annual Report 2010. Hong Kong: Hong Kong Monetary Authority.

Hong Kong Monetary Authority. 2011. "Hong Kong: The Premier Offshore Renminbi Business Centre.” HKMA Publications and Research Reference Materials, September.

Hui, Daniel, and Dominic Bunning. 2010. The Offshore Renminbi: A Practical Primer on the CNH Market. London: HSBC Global Research.

International Monetary Fund. 2011. People's Republic of China: Spillover Report for the 2011 Article IV Consultation and Selected Issues. IMF Country Report 11/193. Washington: International Monetary Fund.

International Monetary Fund. Various years. Annual Reports on Exchange Arrangements and Exchange Restrictions. Washington: International Monetary Fund.

Ito, Takatoshi. 2011. The Internationalization of the RMB: Opportunities and Pitfalls. Council on Foreign Relations Working Paper.

Kose, M. Ayhan, Eswar Prasad, Kenneth Rogoff, and Shang-Jin Wei. 2009. "Financial Globalization: A Reappraisal.” IMF Staff Papers 56(1), pp. 8-62.

Kose, Ayhan, Eswar Prasad, and Marco Terrones. 2009. "Does Financial Globalization Promote Risk Sharing?” Journal of Development Economics 89(2), pp. 258-270.

Kroeber, Arthur. 2011. The Chinese Yuan Grows Up Slowly: Fact and Fiction about China's Currency Internationalization. Policy Paper. Washington: New America Foundation.

Krugman, Paul. 1995. Currency and Crises. Cambridge, Mass.: MIT Press.

Lardy, Nicholas. 2011. Sustaining China's Growth after the Global Financial Crisis. Washington: Peterson Institute for International Economics.

Lardy, Nicholas, and Patrick Douglass. 2011. Capital Account Liberalization and the Role of the Renminbi. Working Paper 11-6. Washington: Peterson Institute for International Economics.

Miniane, Jacques. 2004. "A New Set of Measures on Capital Account Restrictions.” IMF Staff Papers 51(2), pp. 276-308.

Obstfeld, Maurice. 2011a. "The International Monetary System: Living with Asymmetry." Manuscript, University of California, Berkeley, September 2. 
Obstfeld, Maurice. 2011b. "The SDR as an International Reserve Asset: What Future?" Manuscript, University of California, Berkeley, March 27.

People's Bank of China. 2010. Annual Report 2010. Beijing: People's Bank of China.

People's Bank of China. 2011. China Financial Stability Report. Beijing: People's Bank of China.

Prasad, Eswar. 2009. "Is the Chinese Growth Miracle Built to Last?" China Economic Review 20, pp. 103-123.

Prasad, Eswar. 2011. "Role Reversal in Global Finance." National Bureau of Economic Research Working Paper 17497. (Forthcoming in Proceedings of the 2011 Jackson Hole Symposium, Federal Reserve Bank of Kansas City.)

Prasad, Eswar, and Raghuram Rajan. 2008. "A Pragmatic Approach to Capital Account Liberalization.” Journal of Economic Perspectives 22(3), pp. 149-172.

Prasad, Eswar, Raghuram Rajan, and Arvind Subramanian. 2007. "Foreign Capital and Economic Growth." Brookings Papers on Economic Activity, The Brookings Institution, 38(1), pp. 153-230.

Prasad, Eswar, Thomas Rumbaugh, and Qing Wang. 2005. Putting the Cart before the Horse? Capital Account Liberalization and Exchange Rate Flexibility in China. International Monetary Fund Policy Discussion Paper.

Prasad, Eswar, and Shang-Jin Wei. 2007. "China’s Approach to Capital Inflows: Patterns and Possible Explanations." In Capital Controls and Capital Flows in Emerging Economies: Policies, Practices, and Consequences, ed. Sebastian Edwards. Chicago: University of Chicago Press for National Bureau of Economic Research.

Rosen, Daniel H., and Thilo Hanemann. 2009. China's Changing Outbound Foreign Direct Investment Profile: Drivers and Policy Implications. Policy Brief 09-14. Washington: Peterson Institute for International Economics.

Schindler, Martin. 2009. "Measuring Financial Integration: A New Data Set." IMF Staff Papers 56(1), pp. 222-238.

Scissors, David. 2011. "Chinese Outward Investment: More Opportunity than Danger." Heritage Foundation Backgrounder 2579.

Subramanian, Arvind. 2011. Renminbi Rules: The Conditional Imminence of the Reserve Currency Transition. Working Paper 11-14. Washington: Peterson Institute for International Economics.

Tavlas, George. 1991. "On the International Use of Currencies: The Case of the Deutsche Mark.” Essays in International Finance, Princeton University 181 (March).

Yam, Joseph. 2011. A Safe Approach to Convertibility for the Renminbi. Working Paper 5, Institute for Global Economics and Finance, Chinese University of Hong Kong. 


\section{NOTES}

1 A burgeoning literature looking at specific aspects of China's exchange rate management and capital account liberalization includes Frankel (2005, 2011), Eichengreen (2011b), Lardy and Douglass (2011), and Yam (2011).

2 See, e.g., Chen, Peng, and Shu (2009) and Subramanian (2011). Dobson and Masson (2009) and Kroeber (2011) offer a more skeptical view. Angeloni et al. (2011) discuss probabilities of alternative scenarios and argue that the renminbi may gain more prominence if the euro does not mount a serious challenge to the dominance of the U.S. dollar.

3 Other commonly used measures of de jure openness have been created by Schindler (2009) and Miniane (2004). The Schindler data set is only available up to 2005 and shows little variation over time for China. The Miniane data set does not include China.

4 This index takes values from -1.84 (closed) to +2.48 (open). The index for Germany is used instead of that of the euro area because no separate index is available for the latter.

5 See Prasad, Rumbaugh, and Wang (2005) for references and a discussion of this issue in the context of China.

6 See Prasad (2009) for a more detailed discussion of these issues.

7 See Tavlas (1991); Chinn and Frankel (2007); Forbes (2009); and Obstfeld (2011a). For a historical perspective on the role of financial markets for the rise of the U.S. dollar, see Eichengreen (2011a).

8 In the absence of clear documentation, the turnover data for China and Japan in Tables 9 and 10 assume that the original source presents rolling annual turnover data on a quarterly basis. If the turnover data were in fact quarterly measures, then the annual bond turnover for these economies would be higher. For example, the turnover of China's government and corporate bonds in 2010 would be $\$ 7.2$ billion and $\$ 2.9$ billion, respectively. Similarly, the turnover ratio (calculated using the value of outstanding bonds as of December 2010) would be 3.0 and 4.6, respectively. For Japan, the corresponding government and corporate bond turnover would be $\$ 46$ trillion and $\$ 0.3$ trillion, and their ratios would be 4.34 and 0.28 . The 2011 China Financial Stability Report states that the turnover of the nation's interbank bond market was 64 trillion yuan (\$9.6 trillion) in 2010 (PBOC 2011).

9 The Netherlands has the highest rank in terms of interconnectedness; it is a small but very open economy with extensive trade linkages. The systemic trade importance ranks of some other countries are as follows: Germany (2), Korea (7), Japan (9), India (14), Russia (19), and Brazil (20).

10 In addition to these spot rates, other renminbi-related exchange rates are the dollarsettled nondeliverable forwards rate $(\mathrm{NDF})$ and the trade settlement exchange rate. The NDF market predates the $\mathrm{CNH}$ market, and it precludes participation by mainland China residents. However, the NDF is linked to the onshore CNY exchange rate in the sense that its value is derived from expected future CNY spot rates. The trade-settlement exchange rate is the one that prevails for cross-border trade transactions, for which the $\mathrm{CNH}$ rate does not apply. 
11 See, e.g., "Renminbi Threat to Dollar Could be Stalling," Financial Times, November $23,2011$.

12 The Chiang Mai Initiative refers to the initiative of ASEAN+3 economies to set up bilateral central bank swap lines among their members to deal with country-specific liquidity crunches.

13 The swap lines with Korea and Japan were established in 2002 and are two-way-that is, either party can provide liquidity. The swap with the Philippines was established in 2003 and, though denominated in local currency, it is a one-way swap such that China would provide renminbi liquidity in return for Philippine currency should the Philippines need to draw upon the credit line (see Henning 2009; Ito 2011).

14 “Nigeria Approves Inclusion of Chinese Renminbi in External Reserves," Central Bank of Nigeria Press Release, September 5, 2011.

15 "Enhanced Cooperation for Financial Markets Development between China and Japan," People's Bank of China, December 25, 2011.

16 Interestingly, China held a significant portion of short-term U.S. Treasuries in 2009. This, however, decreased quickly in the subsequent year.

17 This is based on a stock of about 204 billion SDRs converted to U.S. dollars at the November 23, 2011, exchange rate of 0.643 SDRs per $\$ 1$.

18 See "China FX Head Proposes Adding BRICS Currencies to SDR," Reuters, May 5, 2011.

19 “IMF Executive Board Completes the 2010 Review of SDR Valuation," IMF Public Information Notice 10/149.

20 "IMF Executive Board Discusses Criteria for Broadening the SDR Currency Basket," IMF Public Information Notice 11/137. For more details on the underlying analysis, see "Criteria for Broadening the SDR Currency Basket," International Monetary Fund, September 2011. 